Ankara Üniversitesi Türk İnklâp Tarihi Enstitüsü Atatürk Yolu Dergisi S 43, Bahar 2009, s. 407-454

\title{
Ellinci Yılına Yaklaşırken 27 Mayıs ve Getirdiği Anayasaya Kısa Bir Bakış
}

\author{
Prof. Dr. Seçil Karal AKGÜN*
}

Yönetenlerin ve yönetilenlerin toplumsal olaylar karşısındaki davranışlarının zaman zaman bunalımlara, savaşlara, ayaklanmalara veya ihtilallere yol açması insanların siyasal bir yapı içinde yaşamaya başlamaları kadar eskiyse de böylece ortaya çıkan olayların nedenleri ve sonuçları hep farklı olmuştur. Bununla birlikte her birinde görülen ortak özellik, tepkiyi yansıtmalarıdır. Askerin veya sivilin başrolü üstlendiği ihtilaller de hep yürürlükteki düzene duyulan tepkiyle baş kaldırıyı temsil etmiştir. Türkiye Cumhuriyeti'nin kurulmasından sonra ilk ihtilal olan 27 Mayıs da iktidarın Anayasayı askıya alan uygulamalarına 1960 ilkbaharında Türk Silahlı Kuvvetleri'nin tepki göstererek ülke yönetimine el koymasıdır. Bu eylem, toplumun yaygın katılımını içermesiyle ihtilal, anayasa değişikliğini içermesiyle de o zamanki söylemiyle inkılap olarak adlandırıldı. Ama zaman içindeki siyasal değişimlerle olay farklı değerlendirildikçe Darbe de denildi İhtilal de. Hatta bir ara "27 Mayıs İnkılabı" olarak Cumhuriyet Tarihi ders kitaplarına eklendi. Resmi tatilli "Bayram" yapıldı. Daha sonra hem kitaplardan hem de bayram ve resmi tatil olmaktan çıkarıldı. Askeri yönetime getiren siyasal ve toplumsal sıkıntıları çözeceği umularak hazırlanıp halk oyuyla yürürlüğe giren yeni anayasa da değişimlere uğradı. Türkiye'ye o zamana kadar hiç olmadığ kadar geniş toplumsal haklar getirdiği için bol geldiği, hatta lüks olduğu söylendi, ilkin rafa kaldırıldı, sonunda büsbütün kaldırıldı. Ne var ki, ne 27 Mayıs, ne de 1961 Anayasası unutulmadı. Olayın acı-tatlı bir çok durağı yıllar geçtikçe belleklerde gitgide küllense de tanıttığ 1 toplumsal haklarla ve çağdaş kurumlarla sadece belleklerde değil, günümüz Türkiyesi'nin yönetim ve hukuk sisteminde de yaşayan Anayasası 27 Mayıs'ın Türk toplumuna armağanı oldu.

\footnotetext{
* ODTÜ, Fen-Edebiyat Fakültesi, Tarih Bölümü
} 
Burada ihtilal densin, darbe densin, ne adla anılırsa anılsın, Türk tarihinin önemli bir kesiti olan 27 Mayıs hareketinin nedenlerini, oluşumunu veya sonuçlarını ele alacak değilim. Bunların her biri, bir makale boyutunu çok aşan apayrı ve ayrıntılı incelemeler ve değerlendirmeler gerektirdiğinden, okumakta olduğunuz sayfalarda olayla ilgili bazı yayınlar, resmi kaynaklar ve anılar ışığında birkaç hatırlamadan öteye gitmeyeceğim. Bunu yaparken olayı tetikleyen siyasal sorunları veya sorumsuzlukları irdelemek yerine, Türkiye Cumhuriyeti için Atatürk'ün günümüzde bir çok noktası gözardı edilen özlemi olan çağdaş uygarlık düzeyine doğru ülkeyi yönlendiren kurumsal değişiklikleri hala sürdürülen 1961 Anayasasının hazırlanışı ve getirilerine kısaca değinmekle yetineceğim. Böylece, söz konusu dönemi yaşamamış kuşakların 27 Mayıs'ı bir bütün olarak ele alıp değerlendirmeleri yönünde bir katkı yapabilmeyi amaçlamaktayım.

27 Mayıs sabahının çok erken saatlerinde radyolarda çalan marşlarla ve Alparslan Türkeş'in Türk Silahlı Kuvvetlerinin ülkenin yönetimine el koyduğunu duyuran sesiyle bütün Türkiye'yi yataklardan fırlatan olay, kuşkusuz bir gecenin getirdiği bir gelişme değildi. Temel nedenleri çok gerilere giden bu hareketin yakın nedenleri, Cumhuriyetin kuruluşundan beri yönetimi elinde tutan Cumhuriyet Halk Partisi'nin (C.H.P.) iktidarı 14 Mayıs 1950'de seçimi kazanan Demokrat Parti'ye bıraktığı günlerde oluşmaya başlamıştı. Katıldığı ilk seçim olan 21 Temmuz 1946'da iktidar koltuğunda değilse de halkın gönlünde taht kurmayı başaran Demokrat Parti'nin (D.P.) dört yıl sonra ezici bir çoğunlukla yönetime taşınması, sadece 27 yıllık tek parti yönetimine bir tepki değildi. Türkiye Büyük Millet Meclisi'nin (T.B.M.M.) kurulduğu günlerden beri Meclis içinde ve dışında var olan ve ulus yerine ümmet'in, ulusal egemenliğin yerine Tanrısal egemenliğin sürmesini yeğleyenlerin düşüncelerinin eyleme dökülmesiydi. Türk siyasal yapısı içinde hiç yok olmayan ve daha T.B.M.M.'nin ilk yıllarında İkinci Grup olarak örgütlenen bu düşüncenin sahipleri, düşmandan kurtuluşu alkışlarken Cumhuriyetin duyurulmasını ve izleyen Türk Devrimi’ni buruk karşılamışlardı. Bununla birlikte Kurtuluş Savaşı'nın zaferi, bu zaferi kazandıran Atatürk'e halk arasında duyulan hayranlık, sevgi, bağımsızlığın coşkusuyla birleşince, bu çevrelerden ne yönetim değişikliğine, ne de getirilen yeniliklere büyük bir karşı koyma gelmişti.

Ne var ki Atatürk'ün ölümü ile çekindiği kale yıkılan İkinci Grup, nerdeyse eş zamanlı olarak patlak veren II. Dünya Savaşı'ndan Türkiye'nin savaşa girmese de derinden etkilemesini değerlendirerek Cumhurbaşkanı seçilen İsmet İnönü'yü ve partisini boy hedefi yapmakta gecikmedi.

İkinci Dünya Savaşı’yla gelen enflasyon, pahalılık, güvensizlik, yatırımların durması, İnönü'yü Cumhurbaşkanı koltuğuna oturur oturmaz büyük ekonomik sorunlarla yüzyüze getirmişti. Hükümet, bir yandan savaş dışı kalmaya çalışıp bir yandan sorumlu tutulduğu bu sorunla boğuşurken 
seferberlik, sıkı yönetim, Avrupa ülkelerinden ithal edilen maddelerin bir çoğunun bulunamaması, bu yüzden artan yokluklar, karaborsacılık ve temel tüketim maddelerinin vesika ile alınması da yönetim partisi ve başkanına fatura edildi. Bu durumda C.H.P. karşıtları yüzyılların geleneklerini yıkmakla suçladıkları Türk Devrimi'ni günah keçisi yapıp halkı savaşla gelen maddi zorlukların hala benimseyemediği yeniliklerden kaynaklandığına inandırmakta ve devrime sahip çıkan hükümete karşı örgütlemekte hiç zorlanmadılar. Yeni bir siyasal örgütlenmeye yönelen bu kesimin gönenç müjdesi veren bir yandan da toplumun çok yabancı olduğu laikliği hedef alan her ödün sözü, baş tacı edildi. Cumhuriyeti ve Devrimin getirmiş olduğu çağdaş değerleri ancak iktidarda kalarak koruyabileceğini düşünen İnönü'nün halkı sabırla eğiterek aydınlatmak yerine karşı tarafın silahlarını kullanmak gibi bir yol seçmesi, en büyük yanılgısı oldu. Yeni oluşumun toprak, tarım ve laiklik konularını işleyip sözler vererek sırtını halkın çoğunluğu olan köylüye ve tutuculara yasladığını görerek o da aynı konulara odaklandı. Ama oy kaygısıyla öğrenim birliğinden köy enstitülerine kadar ülkeyi çağdaşlığa taşıyacak araçlardan verdiği ödünler hiç de inandırıcı olmadı. Tam tersine, güvenilirliğine eksi puanlar kattı. $\mathrm{Bu}$ güvensizliği siyasal platformda dile getirmek isteği, Türkiye'de üçüncü kez çok partili sistem deneyimini tetikledi. Çiftçiyi Topraklandırma Kanunu'nun Meclis'te gündeme getirilmesini Bolşeviklik olarak niteleyen liberal ekonomi yanlısı Celal Bayar, Adnan Menderes, Fuat Köprülü ve Refik Koraltan iktidarın yaptırımlarından yakınmalarını Haziran ayında Dörtlü Takrir'le yazıya döktükten sonra 7 Ocak 1946'da Demokrat Parti'yi kurdular.

Yeni parti hızlı katılımlarla güçlenirken C.H.P., yitirdiği güveni 1947 yılı Şubatı'nda Türkiye'nin Dünya Bankası'na ve IMF'ye üye olması, 15 Nisan 1948 tarihli Avrupa İşbirliği Sözleşmesi'ne katılıması, komünizm tehlikesine karşı ABD'nin yardımını getiren Truman Doktrini ve onu yürürlüğe koyan Marshall Planı, 4 Temmuz'da imzalanan Amerikan Yardımı Anlaşması, 1949'da Avrupa Konseyi'ne üyeliği $i^{1}$ gibi dış bağlantılarla batıya ekonomik entegrasyonun sağlayarak kazanmaya çalıştıysa da bunu başaramadı. Hatta Milli Eğitim Bakanlığı'nın 1948'de aldığ Kur'an Belleme ve Din Bilgileri Dersanesi açabilme ve buralara eleman yetiştirmek için seminerler düzenleme olanağ sayısı 56 olan Kur'an kurslarını on yılda 127'ye çıkarılması, ilkokullara isteğe bağlı din dersleri koyulması, İmam Hatip kursları açılması; Ankara Üniversitesi'ne bağlı İlahiyat Fakültesi'nin kurulması, hatta hatta 1 Mart

${ }^{1}$ Soysal, İsmail, Türkiye'nin Uluslararası Siyasal Bă̆ıtları (1945-1990), Cilt II, Ank.1991, s.286-88, 309-320.

${ }^{2}$ Daver, Bülent, Layiklik, Ank. 1955, s. 223-224. 
1950'de çıkan yasayla bazı türbelerin açılması ${ }^{3}$ bile C.H.P.'ye beklediği yararı sağlayamadı. Ve sonunda 14 Mayıs günü yapılan 1950 seçimlerinde Türk Devrimi'nden ödünler söz vererek 487 milletvekilliğinden 408 'ini ${ }^{4}$ alan D.P., Celal Bayar ve Adnan Menderes'in değişmez yönetiminde verdiği sözleri yerine getirerek on yıl kalacağı iktidar koltuğuna oturdu.

\section{D.P. İktidarı: Yeni Partiyle Gelen Sorunlar}

D.P. döneminin Cumhurbaşkanı, Kurtuluş Savaşı'nın Galip Hoca'sı olarak bilinen eski İttihatçı Mahmut Celal Bayar, Saruhan Milletvekili olarak katıldığı Birinci T.B.M.M.'nde, İktisat, Mübadele, İmar ve İskan, vekillikleri, sonra da başbakanlık yapmıştı. Bayar, Atatürk'e karşı gruplaşmalara hiç rağbet etmediyse de 1950 yılında Cumhurbaşkanı olduktan kısa bir süre sonra, birlikte çalıştı̆̆ 1 uzun yıllar boyunca hiç karşı çıkmadığı İnönü ve C.H.P. ile geçmişini bağlayan köprüleri yıktı. Bununla birlikte Atatürk'e bağlılığını sürdürüp 1955 yazında Florya'da konuğu olan rektör ve dekanlarla sohbeti sirasında "İnkılaplar aleyhine bir hareket olursa anayasayı çiğnemek bahasına onu bastırırım" diyecek kadar Türk Devrimi'ne sahip çıkarken, ilginçtir ki gericilere yeşil 1şıklar, onun Cumhurbaşkanlığı sırasında yakıldı..

Bayar'ın, Başbakanlık görevi verdiği Adnan Menderes'in, Serbest Fırka üyeliğiyle başlayan siyasal yaşamı, bu partinin kapanmasından 1945 yılına kadar Aydın Milletvekili olarak C.H.P.'de, sonrası da kurucularından olduğu D.P.'de geçti. C.H.P.'den mebus oluşunun öyküsünü "Beni Atatürk keşfetti" diye anlatan Menderes, D.P. iktidarı boyunca sürecek Başbakanlığının ilk hükümetinin programını açıkladığı 20 Mayıs söylevinde Atatürk'ün adını anmamış, üstelik, Türk Devrimi'ni tutan ve tutmayan devrimler diye ayırarak millete mal olmayanlarında ssrarlı olmayacaklarının da altını çizmişti. Bu sözün tutulacağının bir göstergesi olarak hükümetin ilk ayı dolarken 18 yıldır Türkçe okunan ezanın dili Arapça döndürüldü. ${ }^{7}$ D.P.'nin ilk yaptırımları arasında Anayasanın da dilinin değiştirilmesi ve Eyüp Sultan Türbesi'nin açılması, programda yazmasa da Atatürk'ün adı gibi ilkelerinden de hızla uzaklaşılacağını anlatıyordu. Sevilmeyen yönleri olsa da Türkiye'yi II. Dünya Savaşına sokmadığından halkın "çocuklarımızı babasız bırakmadı" diyerek sarıldığı İnönü'yü "bize ekmeği bile vesikayla yedirdi" sözleri ile tanımlanan kimse haline getirmek ve C.H.P. ile birlikte kamu oyunun gözünde düşürmek, hükümet programının yazılı olmayan

\footnotetext{
${ }^{3}$ Turan, Şerafettin, Türk Devrim Tarihi, Cilt 4/1, İst. 1999, s. 102-117.

${ }_{5}^{4}$ Aydemir, SSevket Süreyya, İhtilalin Mantığı ve 27 Mayıs İhtilali, Ank. 1973, s. 176

5 Enver Ziya Karal'ın özel arşivinden Kurucu Meclis Notları (Hıfzı Veldet Velidedeoğlu tarafindan nakledilmiş olarak) s.157.

${ }^{6}$ Aydemir, Şevket Süreyya, Menderes'in Dramı, İst. 1993, s.90.

${ }^{7}$ Geniş bilgi için bk: Akgün, Seçil, Türkçe Ezan, A.Ü. Dil ve Tarih Coğrafya Fakültesi Dergisi, Cilt XIII, s. 24, Ank. 198016 Haziran tarihli ve 5665 sayılı yasa ile Türk Ceza Kanunu'nun 526. maddesindeki ezanın Arapça okunmasını yasaklayan fikra kaldırılmıştı.
} 
hedefiydi. Önceki iktidarın önayak olduğu kurumları gereksiz gösterip kapatmak, bu hedefe götüren yöntemlerden biri olacaktı. Nitekim, Menderes'in Hükümet Programı tartışmaları sırasında kuruluşuna katılmış olduğu ve 15 yıl müfettişliğini yaptığı Halkevlerini "gençliği ele geçirmeye yönelik faşist kuruluşlar" olarak tanımlaması ve "..bunlar içtimai yapımız içinde tamamıla abes geri ve yabancı uzuv halindedir." sözlerinden sonra, daha ileri tarihte "Halkevleri içi boşalmış, tarihe karışmış birer varlık halinde idiler. Bunlar partiler için birer utanma konusu teşkil ediyorlardı" ${ }^{8}$ diyerek, kırsal kesime ışık saçan bu aydınlık kurumun kapattırması, büyük toplumsal eleştirilere yol açmadı ve ilk yılın coşkusu içinde eriyip gitti. Yeni uygulamalardan nasibini alan Köy Enstitüleri de Mecliste 'Köy Enstitüleri ile mücadele, komünizmle mücadeledir" diyen Milli Eğitim Bakanı Tevfik İleri başta, Türkiye'ye sol düşünceyi sokan kurum olarak boy hedefi yapıldı ve kısa ömründe sağladığı yararlara bakılmaksızın üç yıllık öğretmen okullarına dönüştürülerek kapatıldılar. ${ }^{9}$

1954 seçimi yaklaşırken D.P. alınan bu kararların doğurduğu hoşnutsuzlukla oylarının bir kısmını kaptıracağından korktuğu rakibinin sesini maddi gücünden yoksun bırakarak kesmeyi düşündü. C.H.P.'nin nüfuzunu kullanarak haksız kazanımla elde ettiğini öne sürdüğü tüm mal varlığının hazineye iadesini sağladı. Tam seçim aşamasında C.H.P.'yi halkın gözünde yıpratmayı da hedefleyen tasarı Meclis’te görüşülürken önerilenin devletin devamlılığına ve Anayasaya aykırı olduğunu hatırlatan İnönü'nün "Tarih kürsüsünden halinizi seyrediyorum. Suçluların telaşı içindesiniz" sözlerine Başbakan tek parti döneminde Meclis'i sadece eşkıya ve siyasi haydutların doldurduğu yanıtını verirken, C.H.P. kanadının salondan çıkmasını izleyen oylamada yasanın 5 olumsuz oyla kabul edilmesiyle ${ }^{\mathbf{1 0}}$ iki parti arasındaki uçurum bir daha hiç kapanmayacak kadar derinleşmişti.

C.H.P.'nin Meclis'e sadece 31 mebus sokabildiği 1954 seçiminde D.P.'ye \% 92.28 oyla 503 koltuk kazandıran toplumsal destekten güç alan Menderes'in, İsmet Paşa'yı şahsen hedef alan söylevlerinin çoğalması, C.H.P. karşıtlarını yüreklendirdi. Neredeyse düşmanlığa tırmanan duygularla heykel saldırıları başladı. Atatürk'ün yurdun çeşitli yerlerindeki büstleri ve heykelleri neredeyse her gün saldırıya uğradı veya yıkıldı. Heykellere sallanan kazmalar taşı betonu kırıyordu ama asıl hedef, Atatürk'ün topluma kazandırmak istediği çağdaş, laik, özgür düşünceydi. Yıkıcılar, onun düşüncelerini yıkamayacaklarını gördükçe taşlara yönelen D.P. ile birlikte yaşama dönen tarikatçılardı. Nurcular ve özellikle önceden adı pek duyulmamış Ticanilerdi. Demokrasiyi daha çok laikliği gözardı etmek gibi

\footnotetext{
${ }^{8}$ Aydemir, Şevket Süreyya, Íhtilalin Mantığı ve 27 Mayıs İhtilali .s.196-197.

${ }^{9}$ Turan, Şerafettin, a.g.e. s. 51,Köy Enstitüleri 27 Ocak 1954 tarihli ve 6234 sayılı yasa ile son buldu.

${ }^{10}$ T.B.M.M. Tutanak Dergisi, Dönem IX, Cilt:26 İçtima 4, 14.12.1953 s.160-237.
} 
yorumlayan Hükümetin hoşgörüsüne sı̆̆ınan bu sapkınların eylemleri kamu oyunda tepkiler doğurunca Meclis'ten Atatürk'ü Koruma Yasası çıkarıldıysa da bunun Atatürk'ün düşüncelerini korumakla hiçbir ilgisi olmadığ $\breve{1}$ hemen anlaşıldı. ${ }^{11}$ Bu yönde başlayan eleştirilerin halka halka genişlediğini gören hükümetin önlemi, karşı koyanları susturacak sert yöntemler geliştirmek oldu.

Ne var ki D.P. Grubuna "Siz isterseniz halifeliği bile geri getirebilirsiniz" derken Başbakanı çılgınca alkışlayanlar, bir süre sonra bu sözler sertleşip 'Ben bu millete odunu aday göstersem, onu bile mebus seçtiririm'e dönüştüğünde D.P.'yi sorgulamaya başlamışlardı bile. NATO'ya üye olabilmek için Meclis'ten yetki alınmadan Türk askerinin gönderildiğgi ${ }^{12}$ Kore Savaşı'nda yitirilen canlar, Kıbrıs Sorunu 1954'de kurulan EOKA'nın bir yıl içinde adadaki Türklere karşı genişlettiği saldırılarla alevlenince İstanbul ve İzmir'de Rumları hedef alan 6-7 Eylül olayları, Müslüman olmayan vatandaşların yakılıp yıkılan kiliseleri, evleri ve yağmalanan iş yerleri için devletin yüz milyon liraya yakın tazminat ödemek zorunda kalması, bu olayda hükümetin parmağı olduğu söylentileri, ${ }^{13}$ birden gelişen Amerikan dostluğu, Başkent sokaklarında motosikletler üzerinde cakayla dolaşan Amerikalı MP'ler (Askeri Polis) de bu sorgulamaya katkılı olmuştu. Üstelik II. Dünya Savaşı'nın sona ermesinin getirdiği geçici ekonomik rahatlama sırasında iktidara gelen D.P.'nin, bu dönem arkada kaldıkça hükümet programında yer alan tarım sektörünün kalkındırılması, üretime dönük politikayla ulusal gelirin arttırılması gibi dört gözle beklenen sözlerini yerine getiremediği de gitgide fark edilmekteydi.

D.P. İktidarının başlangıcında kırsal kesimde ekim alanları çoğaltılmış, köylere traktörler girmiş, tarım kredileriyle üretim artmış, kırsal alana gelen büyük hareketlilik herkesin yüzünü güldürmüştü. Ama hükümetin bu yatırımları derinine planlamadan yapması hazineyi zorlarken, fonların kullanımında ülke ekonomisini güçlendirilmek yerine örneğin, eşit sayıda okul ve cami yapmak, ${ }^{14}$ köylüye mutlaka ekim alanı sağlamak gibi oy

${ }^{11}$ İsmet Bozdă̆’ın derlediği Celal Bayar'ın "Başvekilim Adnan Menderes" kitabında (İst, baskı tarihi yok-s.151-152) Ticani tarikatından başkanı Pilavoğlu da içinde olmak üzere 23 tarikatçının tutuklanarak mahkemeye sevk edildiğini, çıkarılan yasanın da bir gecede 17 Atatürk büstünün bile kırıldığı ortamı sona erdirdiğini -verilen cezalardan söz etmedenyazmaktaysa da bilinen, sözde kalan önlemlerle tarikatların kökünün kazınmadığı gibi, Atatürk'ün anısına saldırıların da durmadığıdır.

${ }^{12}$ Aydemir, Şevket Süreyya, Menderes'in Dramı, s. 484.

${ }^{13}$ Şevket Süreyya Aydemir, İkinci Adam kitabında uzun ayrıntılarla söz ettiği yaklaşık 5000 iş yerinin yakılıp yıkılıp yağmalandığ 1 ve 7 kilisenin saldırıya uğradığ 1 olay sırasında İstanbul'da Sık1 Yönetim Komutanlığına getirilen General Nurettin Aknoz'un İçişleri Bakanı Namık Gedik'in, daha sonra da bizzat Başbakan'ın vur emrini yerine getirmemesini çok yerinde bir yorumla "Yakın tarihimiz ....... Aknoz Paşa'ya bu hareketi için birşeyler borçludur" satırlarıyla anlatmaktadır. (Cilt III, s. 187-198).

${ }^{14}$ Walter F. Weiker, Amerikalı, Fransız, Rus Gözüyle 1960 Türk İhtilali, çev. Mete Ergin, İst. 1967, s.17. 
sandığını güçlendirilmeye öncelik vermesi, beklediği gönence kavuşamayan köylüyü de başlangıçta göremediğini görüp iktidara eleştirel bakmaya yöneltti. Tarım alanlarının genişlemesi için ormanlar feda edildikçe ormansızlıktan suların kuruması, meralar azaldıkça, hayvancılığın inişe geçmesi $^{15}$ üretimi hayli örselemeye başlayınca hükümetin sırtını yasladı $\breve{g} 1$ yabancı sermaye de ekonomiyi güçlendiremedi. Altın ve döviz stokları ABD ile geliştirilen sıkı ekonomik ilişkilerle tarım ülkesi olan Türkiye'de buğdaya kadar varan ithalatla erirken Bayar'ın bu ülkeye yaptığ 1 geziden dönüşünde özenti içinde "Türkiye Küçük Amerika olacaktır" sözü, Büyük Türkiye olmak isteyen duyarlı vatandaşları çok incitti.

Olumsuz hiçbir yorum duymak istemeyen iktidarın olumsuzlukları yansıtan basına sansür uygulaması, gazetelerin kapatılması, gazetecilerin yazdıklarını 1spat hakkından yoksun bırkılarak tutuklanması olağan uygulamalar haline gelirken bunlara atamalarla oynayarak yargıya, siyasi kısıtlamalarla üniversiteye, partizan uzaklaştırmalarla bürokrasiye müdahalelerin eklenmesi, baskıcı iktidardan hoşnutsuzluğu arttırdı. Bazı mebusların görevlerinden yararlanarak hileli, usulsüz, hatta haksız kazançlara yönelmeleri, kaçakçılık olaylarına karışmaları, bazılarının da koltuk kaygısıyla yöneticileri uyarmaktan kaçınmaları, ${ }^{16}$ bir yandan da kulaktan kulağa duyulanları halkın sokakta, öğretim üyelerinin derslerinde protesto etmeleriyle bu hoşnutsuzluk nerdeyse düşmanlığa dönüştü. 1956 ders yılı açılırken ülkede pek çok şeyin iyi gitmediğini dile getiren Siyasal Bilgiler Fakültesi Dekanı Prof. Dr. Turhan Feyzioğlu'nun, ardından, İstanbul Hukuk Fakültesi Prof. Dr. Hüseyin Nail Kubalı'nın "vekalet emrine" alınmaları,${ }^{17}$ erkene alınan seçimden önce aydını susturma savaşının açık duyurusu oldu.

\section{Demokrat Parti Demokratik Parti Olamıyor}

1957 seçimlerinde D.P.'nin milletvekili sayısının azalarak C.H.P.'nin 178'ine karşılık 424'de kalması, ${ }^{18}$ halkın iktidardan beklediğini bulamadığını gösterirken D.P.'nin hızlı çöküşünün de başlangıcı oldu. Gözünü kapatan perdeyi bir türlü aralamayan hükümet sanki halkın sabrını sınamaya çalışırmışçasına seçimde oylarını alamadı̆̆ı Kırşehir'i ilçe yaparak, İnönü'ye oy veren Malatya ilini de parçalara ayırarak cezalandırdı. Kırşehir ile ilgili kararın bir süre sonra geri alınmasıysa, hükümeti ancak

${ }^{15}$ Aydemir, Sevket Süreyya, a.g.e. s. 218-220.

${ }^{16}$ Koçaş, Şadi, Atatürk'ten 12 Mart'a, İst. 1977, s.309, 333.

${ }^{17}$ Karakaya, Nihat, Prof. Dr. Turhan Feyzioğlu, Demokrasi, Laiklik ve Cumhuriyete Adanmıs Bir Ömür, Ank. 2008, s. 46. Milli Eğitim Bakanlığı'nın ilgiliye Bakanlık birimleri içinde başka görev vermesini gerektiren bu ceza, aslında hocalara işten el çektirilmek anlamındaydı.

${ }_{18}$ Bu seçimde C.H.P.'nin 3.317866, yani \%41.03 oyuna karssllı D.P. \%47.91 olan 4.384893 oy almışsa da oy kaybederek \%50nin altına düşmüştü. Ş.S.Aydemir, İkinci Adam Cilt III, s. 274. 
daha yıprattı. Bu olayın ardından 9 subayın darbe girişiminde bulundukları suçlamasıyla göz altına alınması, yeterli soruşturma yapılmadan tutuklanmaları, 5 ay sorgulamadan sonra biri hariç, beraat etmeleri hükümetin yıprandığını doğrularken iktidar karşıtları arasına orduyu da katmıştı. ${ }^{19}$ Cumhuriyetin koruyucusu Ordu, haklı olarak tedirgindi. İzleyen gelişmeler de bu haklılı̆̆ 1 derinleştirdi:

Dış borçlar tırmanırken dış yardım alabilmek için 1958 Ağustosu'nda moratoryum duyuruldu ve Türk parası \% 69 değer kaybetti. ${ }^{20}$ Aynı sıralar, hükümetin üç yıl önce imzalanan Bağdat Paktı ile büyük yakınlık sağladı̆̆ Irak'ta askeri ihtilalle krallık rejimi devrildi, Haşimi hanedanı yok oldu. Bu iktidarı ihtilal fobisine iterken, Sovyetler Birliği'nin Orta Doğu ülkeleriyle ilişkilerini geliştirmesi, sola karşı korunma isteğini de körükledi. Hükümet bu güvenceyi ihtilalden sonra dağılan Bağdat Paktının yerine tam bu amaçla, yani bölgede Sovyet etkinliğini önlemek için kendinin üye olmadığı CENTO* nun kurulmasını sağlayan, Amerika'da buldu. Bu ülkeyle Türkiye'yi büyük bağımlılıklar altına sokan bir dize ikili anlaşmalar imzaladı. 5 Mart 1959'da imzalanan, 6ncı maddesi gereği "imzası gününde" hemen yürürlüğe giren ama 14 ay sonra Meclis'e getirilerek 9 Mayıs 1960'da onaylanan ikili anlaşmayla ${ }^{21}$ hükümetin ABD'nin ülkeyi

${ }^{19}$ Toker, Metin, İsmet Paşa ile 10 Yll (1954-1960) Ankara, 1966, s. 31-33.

${ }^{20}$ T.B.M.M. Zabıt Ceridesi, 1960, Devre XI, Cilt:12 İçtima 3, 19 Şubat 1960, s. 1448

* Central Treaty Organization-Merkezi Andlaşma Teşkilatı

${ }^{21}$ Soysal, İsmail, Büyükelçi, Türkiye'nin Uluslararası Siyasal Bă̆ıtları (1945-1990) Cilt II, Ank.1991, s. 507-508. Türkiye Cumhuriyeti adına Fatin Rüstü Zorlu ve ABD adına Türkiye Büyükelçisi Fletcher Warren'ın Ankara'da imzaladıkları bu anlaşmanın maddeleri şöyleydi:

Madde 1:Türkiye Hükümeti saldırıya karsı koymağa kararlıdır. Türkiye’ye saldırı olursa Amerika Birleşik Devletleri hükümeti, Türkiye Hükümetine, istemi üzerine, yardım etmek için, birlikte üzerinde anlaşmaya varılabilecek biçimde ve Orta Doğu'da barış ve istikrarı sürdürmeyi amaçlayan Ortak kararda öngörüldüğü üzere, silahlı kuvvetlerin kullanılması da kapsam içine girerek, A.B.Devletlerinin Anayasasına uygun gerekli her türlü harekete girişecektir.

Madde 2: A.B.D. Hükümeti, değişikliğe uğramıș 1954 Karşılıklı Güvenlik Kanunu, Amerika Birleşik Devletlerinin ilgigli öbür kanunları ve Türkiye Hükümeti ile A.B.D. Hükümeti ile bugüne kadar yapılmıș ve bundan böyle yapılacak olan bundan böyle yapılacak olan bu konuda uygulanabilecek anlaşmalar gereğince, ulusal bağımsızlık ve toprak bütünlügüünün korunmasında ve ekonomik gelişmesinin etkin biçimde sürdürülmesinde Türkiye Hükümetine yardım etmek amacıyla, Türkiye Hükümeti ile A.B.D. Hükümeti arasında karşılıklı olarak üzerinde anlaşmaya varılabilecek askersel ve ekonomik yardımda bulunmağı sürdüreceğini yineler.

Madde 3: Türkiye Hükümeti, A.B.D. Hükümeti tarafından sağlanacak askersel ve ekonomik yardımı 28 Temmuz 1958'de Londra'da imzalanan Bildirgeye katılan Hükümetlerce belirlenmiş amaç ve niyetlere uygun olarak ve Türkiye'nin ekonomik kalkınmasını etkin biçimde özendirmek ve ulusal bağımsızlık ve toprak bütünlüğünü korumak amacıyla kullanmağ 1 yükümlenir.

Madde 4: Türkiye Hükümeti ve A.B.D. Hükümeti, bu Anlassmanın uygulanabilir öbür hükümlerine bağlı olmak üzere, karşılıklı olarak kabul edilebilirliği konusunda anlaşmaya varabilecek savunmöa düzenlemeleri hazırlamak ve bunlara taraf olmak için 28 Temmuz 
komünizme karşı silahla koruması için Türk topraklarında askeri üsler, tesisler kurmasını ve bunlarla gelen ayrıcalıkları onaylaması, yönetimin saygınlığına gölge düşürdü.

Hükümetin Cumhuriyetin temel değerlerinden sonra bu kez de bağımsızlığından ödün verdiğini gören Türk ulusunun haksızlıklara, keyfiliğe gözlemci kalması gitgide daha zorlaşıyor, askerden beklentiye itiyordu. Nitekim, kimi genç subaylar aralarında gidişi ciddi biçimde eleştiren görüşmeler yapıyorlardı. ${ }^{22}$ Ama hükümetin seçime gitmek gibi çok kolay çözümü olabilecek olayları çözümsüz gibi görerek baskıya, şiddete, usulsüzlüğe daha sıkı sarılması, aydına sırt çevirip olanları değerlendiremeyen bilinçsiz kesimlerin desteğini koruyabileceği ödünleri çoğaltması, olumsuzlukları da çoğaltıyordu. Başbakan'ın artık hiç konuşmadığ İ İönü'nün Ege seyahati sırasında Uşak'ta hükümetin perde arkası desteğiyle oluşturulan karşıt gruptan bir kimse tarafından başına taş atılmasi $^{23}$, halka konuşmak üzere gittiği Topkapı'da düzenlenmiş saldırının ortasında kalması ve oradan geçmekte olan bir binbaşının olaya müdahale ederek onu linçten kurtarması, aslında İnönü'nün şahsında laik Türkiye Cumhuriyeti'ne saldırılardı. İnönü'nün gezilerinde ortaya çıkan bu olaylar karşısında kopan fırtına, Ankara'nın yerel yetkililerden dağıtılmasını istediği kalabalıkların İsmet Paşa'nın etrafında ördüğü sevgi yumakları, hele 1960 'da erken seçim olacağı söylentileri üzerine propaganda turlarına başlayan İnönü'nün Kayseri'ye girmesini önlemek buyruğuyla trene gönderilen askeri birlikteki her subayın ve erin karşılarında beliriverdiğinde Paşa'nın saygıyla elini öpmesi, askeri birliklerin yol boyunca selam durarak Ankara'ya güven içinde dönmesinin sağlanması hükümete çok çarpıcı uyarılard 1 .

Uyarıları değerlendirmek bir yana, Hükümet, C.H.P.'ye karşı sanki bir meydan savaşı içindeydi. Irak ihtilalinden oldukça sarsılan Adnan Menderes "Bu demokrasi değil bu bir kan davasıdır" diyebilecek kadar bir duygu seline kapılmıştı. Bunu açıkça dile getirip "Ehlisalip" yani haçlılar cephesi olarak adlandırdığı C.H.P.’lilere karşı öfkesini “..beni devirmek için ihtilal yolunu da deneyeceklerdir. Fakat benim de her türlü vasitayı kullanmak hakkımdır" diyerek; 6 Eylül'de Balıkesir'de C.H.P.'nin niyetinin seçimsiz

1958'de Londra'da imzalanmış olan Bildirgeye katılan öbür Hükümetlerle işbirliği yapacaklardır.

Madde 5: İşbu anlaşmanın hiçbir hükmü öbür uluslararası anlaşma ve düzenlemelerde öngörülen iki hükümet arasında ki işbirliğini etkilemez.

22 Koçaş, Sadi, a.g.e. s.328-30. Koçaş bu kısımda bizzat karşılaştığı eleştirileri anlatmaktadır.

${ }^{23}$ Aydemir, Şevket Süreyya, Íkinci Adam, İst. 1968, Cilt III s. 402, 382 Çeşitli kaynaklarda pek çok görgü tanığ 1 olan Uşak olayının C.H.P. tarafından D.P.'yi yıpratmak için düzenlenen bir düzmece olduğu öne sürülmüştür Bunlara örnek olarak Ali Fuat Başgil'in Fransızca olarak yayınladığı ve M.Ali Sebük ve İ. Hakkı Akın tarafından Türkçeye çevrilen 27 Mayıs İhtilali ve Sebepleri (İst. 1966, s. 116) kitabını gösterebiliriz. 
iktidara gelmek olduğunu öne sürerek, 21 Eylül'de de İzmir'de "Bir daha valiye, kaymakama, savcıya şunu bunu yapacağız derlerse Demokrasiye Paydos!" diyerek belirtmişti.. İnönü'nün demokrasiyi paydos etmeye kalkışanın ve etrafındakilerin başlarına memleketin yıkılıp zindana sokulacakları yanıtına karşılık Bayar'ın 29 Kasım'da Çorlu'dan “Milli kalkınmaya mani olmak isteyenler milli irade karşısında karınca gibi ezileceklerdir" diye seslenmesiyle süren karşılıklı atışmalar uzayıp gitmekteydi. ${ }^{24}$

Ortam gerildikçe değişik grupların C.H.P.'nin yanında toplanmasının doğurduğu telaşla Menderes, D.P.'nin gücünü göstermek ve hala çoğunluğun desteğine sahip olduğunu en yaygın biçimde anlatmak gereğini duyarak gizli adı Demokrat Parti olan Vatan Cephesi kurdurdu. "Üç beş ay içinde Halk Partisini boş çuvala çevireceğim" ${ }^{25}$ diyerek sarıldı̆̆ 1 bu propaganda yönteminin ne denli koyu bir partizanlıkla halkı böldüğüne aldırmadan kısa zamanda hayali isimlerle de çoğaltılan üyelerin listesinin her gece iktidarın tekelindeki radyoda okunmasını sağladı. Televizyon henüz Türkiye'ye girmediğinden herkesin haber almak için radyolarına kilitlendiği o günlerde Radyo Gazetesi "Meşruluk vasfını kaybeden Cumhuriyet Halk Partisi, ihtilal bayraktarlığ 1 yapan tehlikeli bir fesat ocağ 1 haline gelmiştir....kardeşi kardeşe vurdurmak teşebbüsünün son derece tehlikeli ve meşum yolu üzerinde bulunuyor" suçlamasını yaparken Menderes ve Bayar halk huzursuzluğunu anlatan sokak gösterilerinin çoğalması üzerine sıkı yönetim olasılığını görüşmeye başlamışlard.$^{26}$

$\mathrm{Bu}$ açık savaş havası içinde ihtilal söylentileri tırmanırken elbette yöneticilerin kulaklarına da çarpıyordu. Bakanlarla özel bir görüşmede "Tehlikeli vaziyetteyiz. İcab ederse diktatörlükle idare edeceğiz" diyen Cumhurbaşkanı, C.H.P.'nin önergelerini Mecliste gündeme getirtmemekle çok müşkül durumda kaldığından yakınan Meclis Başkanı Koraltan'a "Bunda ne var" diyor, ama Milli Savunma Bakanı'na Çankaya'ya bir saldırı olduğunda doğrudan emir verebilmek için Muhafız Alayı'nın Köşk’e bağlı olması gerektiğini söyleyerek kaygısını da açıklamış oluyordu. Başbakanın görevini bırakmamak için silaha dahi müracaat edeceğini, radyo mücadelesiyle İsmet Paşayı mahvedeceğini, partisini eriteceğini, seçimi kaybedeceğini hissederse Halk Partisini kapatıp yine iktidarda kalacağını söylediği Kabine üyeleri arasında konuşuluyordu. İktidarı ne bahasına olursa olsun bırakmamak görüşüne Dışişleri Bakanı Zorlu da "Tek çare vardır,

\footnotetext{
${ }^{24}$ Aydemir, Şevket Süreyya, İhtilalin Mantı̆̆l ve 27 Mayls İhtilali, s. 296-298

${ }^{25}$ Küçük, Sami, Rumeli'den 27 Mayıs'a, İst. 2008, s.67

${ }^{26}$ Sungur, Avukat Hasan Halis, Anayasayı İhlal Suçları ve T.C.K. 146 cı maddesi hükümleri-sakıt iktidarın sorumluluğu, İstanbul $1961 \mathrm{s.78-80}$
} 
Halk Partisini kapatmak ve bütün mebuslarını tevkif ettirmek" diyerek kat1liyordu. ${ }^{27}$

Artık sağduyusunu iyice yitirmiş hükümetin C.H.P.'yi kapatmayı ve basını iyice susturmayı hedefleyerek Türkiye Büyük Millet Meclisi Tahkikat Encümenlerinin Vazife ve Selahiyetleri Hakkında Kanun'un 27 Nisan'da Mecliste kabulünü sağlayıp 15 milletvekilini neredeyse yargı organının yetkileriyle donanmış Tahkikat Komisyonu'nda görevlendirmesi üzerine olayların iyice tırmanması 'Meclis'teki çoğunluğun parlamenter düzenin hukuksal temeli olmaktan çıkarak iktidarın genel baskısının dayanağ ${ }^{28}$ haline gelmesine tepkiydi Gerçekten de Komisyon asker ve sivil tüm adli yetkileri elinde tutacak, yayın yasağı getirebilecek, gazeteleri toplatıp matbaalarıyla birlikte kapatabilecek, siyasal toplantı veya gösteriyi engelleyebilecek, her türlü evrak, belge ve eşyaya el koyabilecekti. Hiç bir şekilde itiraz edilemeyecek olan Komisyon kararlarına uymayanlar hapisle cezalandırılacaktı ${ }^{29}$ Umulmadık derecede büyüyen olaylar üzerine hükümetin danışmak için Ankara'ya çağırdığg İstanbul Üniversitesi Hukuk Fakültesi profesörlerinden Ali Fuat Başgil, Bayar, Menderes, Koraltan ve Zorlu ile yaptığı özel görüşmede söz konusu yasanın içeriğinin Anayasa ile çeliştiğinden geri alınması gerektiğgine işaret etmiş, ayrıca, öğrencilerin gönderilen polisle çatışırken askerle kucaklaştığını gördüğünü anlatıp güç kullanarak gençliğin üzerine gidilmemesi, hatta, hükümetin çekilmesi yönünde uyarılarda bulunmuştu. ${ }^{30}$ Zaten tasarı çıkarken bir uyarı da Meclis'te bunun Anayasaya, hatta insan haklarına aykırı olduğunu vurgulayarak belli koşullarda uluslar için ihtilalin meşru bir hak olduğunu hatırlatıp "Bu yolda devam ederseniz sizi ben bile kurtaramam"31 diyen İnönü'den gelmişti.

İnönü'nün söylediği gibi hükümetin hakime, memura, orduya güvensizlik anlamına gelen ve anayasayı göz ardı eden yasayı geçirmesine karşı koyan İnönü'nün uyarı sözlerinin tutanaklardan çıkarılması ve ceza olarak Meclis toplantılarına 12 oturum katılmaması kararına ${ }^{32}$ tepkisini gençlik, meydanlarda dile getirdi. Usulsüz, gerekçesiz hakim sürgünleri ve atamalarıyla yargıyı, 9 Subay olayı ve Başbakan'ın "battalgazi ordusu" "biz istersek orduyu yedeksubaylarla da idare ederiz" ${ }^{\prime 33}$ gibi sözleriyle orduyu

${ }^{27}$ Küçük, Sami, a.g.e. s.66-69 Küçük, bu bilgileri ilgili kimselerin günlüklerinden alıntılarla vermektedir.

${ }^{28}$ Soysal, Mümtaz, Anayasaya Giriş, Ankara 1968, s.141

${ }^{29}$ Feridun, Dr. Server, Anayasalar ve Siyasal Belgeler, İst. 1962 s.64-65 Türkiye Büyük Millet Meclisi Tahkikat Encümenlerinin Vazife ve Selahiyetleri Hakkında Kanun, (Say1:7468)

${ }^{30}$ Başgil, Ali Fuat, 27 Mayıs İhtilali ve Sebepleri, İst. 1966 (Fransızca'dan çeviren: M. Ali Sebük ve İ. Hakkı Akın) s.128-138.

${ }_{31}^{1}$ T.B.M.M. Zabıt Ceridesi, 18 Nisan 1960, Devre XI, Cilt:I3 İçtima 3, s. 207.

${ }^{32}$ İbid. s. 189 v.d.

${ }^{33}$ Karavelioğlu, Kamil, Bir Devrim İki Darbe, İst. 2007, s. 68. 
adım adım karşısına alan hükümet için artık üniversiteler de susturulması gereken boyhedefiydi. İstanbul üniversiteleri öğrencileri ve hocalarının çoğunun katıldığı 28 Nisan eyleminde Rektör Sıdık Sami Onar karşıt gruplar tarafından tartaklanıp yaralandı. Polise ateş emri verilince Orman Fakültesi öğrencisi Turan Emeksiz öldürüldü. Eş zamanlı olarak Ankara'da Siyasal Bilgiler Fakültesi'nin polis tarafından taranması, çok sayıda öğrencinin yaralanıp bir o kadarının tutuklanması meydanlara açılan sokaklara tankları, halka da sıkıyönetimi ve sokağa çıkma yasağını getirdi. Ama ortalık durulmuyordu. İkinci kurban da Ankara'da verilmişti. Olaya kan karışmıştı. Üniversiteler kaynıyor, basına uygulanan sansürle kulak gazetesi her zamankinden çok satıyordu. Tutuklanan üniversite öğrencilerinin kıyma makinelerinde yok edildiği, C.H.P.nin kapatılacağ 1 , üniversite öğretim üyelerinin bazılarının tutuklanacağı doğruluğu sorgulanmayan yaygın söylentilerdendi. Kamu desteğini yitirmiş hükümete güven de kalmamıştı. Artık evlerde bile günlük olaylar dışardan dinlenme kaygısıyla pencerelerin önünde biri olup olmadığı kontrol edilerek alçak sesle konuşuluyordu. Hele Başkent'teki bazı öğretim üyelerinin ve yüksek bürokratların kapılarına bir gece tebeşirle çiziliveren $\mathrm{X}$ işaretleri, bu kimselerin idam edileceği söylentilerine bile yol açtt. ${ }^{34}$

O günlerde sanki toplumun üzerine bir karabasan çökmüştü. Olayların önüne geçileceği düşünülerek sıkı yönetimin duyurulması daha çok insanı sokağa döktü. Polisin yürüyüşleri ve sokak gösterilerini göz yaşartıcı bombalarla dağıtması yenilerini başlatınca üniversiteler tatil edilerek ve Ankara'da beş kişiden kalabalık grupların bir arada bulunması yasaklanarak kalabalıklar susturulmaya çalışıldı. Bunun üzerine 5 Mayıs saat 5 'te Kızılay'da ünlü $555 \mathrm{~K}$ mitingi düzenlendi. O gün neredeyse bütün Ankara oradaydı. Kalabalığın arasına yerleştirilen ısmarlama taraftarlarla toplananları kazanabileceğini düşleyen Başbakan miting saatinde Bayar'la Çankaya yönünden gelip arabasından inince "İstifa Menderes" bağrışlarıyla karşılandı, tartaklandı ve oradan kaçırıldı. Aynı havayı sürdüren gençlerin bir araya gelmesinden korkulduğu için ilk kez 19 Mayıs günü olagan gösteriler yapılmadı. ${ }^{35}$ Ertesi gün Menderes'in Türkiye'yi ziyaret eden Hindistan Başbakanı Nehru'yu karşılamış olarak Kızılay'dan geçerken ortalığı inleten “yuh!” seslerinin konuğa sevgi sözcükleri olarak tercüme edildiği, fıkra gibi kulaktan kulağa dolaştı. 21 Mayıs'ta Harp Okulu öğrencilerinin başlarında komutanlarıyla Lozan Meydanı'na hiç beklenmeyen yürüyüşünü ise bazıları umut, bazıları sevinç, bazıları da kaygıyla izledi.

${ }^{34}$ Canlı tanığı olduğum ve o günlerde birçok kimsenin de yaşadığı bu sıkıntılı konuşmalar ve kulaktan kulağa yayılan asıllı asılsız söylentiler, halkın haber kaynakları susturuldukça artan güvensizliğinin göstergeleriydi.

${ }^{35}$ Geleneksel 19 Mayıs gösterileri, 26 Haziran'da büyük coşku içinde yapıldı. 
$\mathrm{Bu}$ olaylarla Ankara'nın iktidar için gitgide daha sıkıntılı olan havasından uzaklaşıp iyi karşılanacağını umduğu Ege bölgesine bir türlü resmen duyurulmayan seçim gezileri yapan Menderes, birkaç kez "biz istersek onların çanlarına ot tıkarız" sözleriyle gündeme getirdiği üniversite hocalarına Turgutlu'da "kara cübbeliler" dediği konuşmasının halka son seslenişlerinden biri olduğunu bilmiyordu. O sıralar silahlı kuvvetler de, ihtilalin son hazırlıklarını yapıyordu. İktidarın, en çok da iyice benmerkezci olan Başbakanın gitgide demokrasiden uzaklaşması, kamu oyunun beklentili ve sorgulu gözlerini üzerinde toplayan ordunun özellikle alt kademelerini çoktandır patlamaya hazır bomba haline getirmişti. Sonu gelmeyen konuşmalarla bir yere varılamayacağ 1 görülünce daha büyük kararlılıkla eylem hazırlığı derinleştirilmiş, hareketin başarısı için ordunun hiyerarşi geleneği gözardı edilmeyip lider olarak Orgeneral Cemal Gürsel'in adı öne çıkarılmıştı.

1958'de Kara Kuvvetleri Komutanlığına getirilmiş olan Orgeneral Gürsel askerler tarafından sevilen, sayılan bir komutandı. Ülkedeki huzursuzlukların iyice arttığ 1959 yılı başında o zaman yarbay olan Sadi Koçaş ordunun harekete geçebileceğini çıtlattığında Gürsel bu sorunun sandık başında en akılcı çözüme ulaşacağını öğütlerken "sakın onlar meşruiyetlerini açıç̧a kaybetmeden bir müdahalede bulunmayın"36 diyerek de gerektiğinde de başlarında olacağını ima ederek genç subaylara rahatlatıcı bir güvence olmuştu. Ne var ki İnönü’nün Kayseri gezisi sırasında bazı subayların tutuklanmasına tepki göstermesi Bakanlıkla arasını açınca ordudan ayrılmaya karar vermiş, bunun üzerine bitim tarihi emekliliğiyle örtüşecek şekilde zorunlu izine ayrılırken Başbakan'a çok yakın bir kimse olan Milli Savunma Bakanı Ethem Menderes'le görüşüp bir de uyarı-öneri mektubu vermişti. ${ }^{37}$ şöyleydi:

${ }^{36}$ Koçaş, Sadi, a.g.e. s.450-452

${ }^{37}$ Kamil Karavelioğlu'nun adı geçen kitabında (s. 108-109) yer alan mektubun içeriği

Dün geceki konuşmalarımızın 1şığı altında zatıalinize memleketin huzur ve istikrarı için alınması lazım gelen tedbir ve kararlar hakkındaki görüşlerimi bildirmeyi milli ve vatani bir vazife bilirim.

Sayın Başvekilin açıklamalarını dinledim ve okudum. Bunlarda, benim düşüncelerimin kabulüne müsait bir zemin henüz mevcut olmadığı aşikar olarak belli ise de, gene de düsüncelerimi sizlere iblağının zaruretine inanıyorum. Muhterem vekilim, su hakikati kabul etmek lazımdır ki Kayseri hadiseleri ile başlayıp son karar ve feci olaylara kadar devam eden vakalar, vatandaş ruhunda derin tesirler ve Hükümete karşı telafisi güç hoşnutsuzluklar yaratmıştır. Hele ordunun talebelere karşı akılsızca kullanılması işin vehametini arttırmış, Ordu mensuplarında huzursuzluk ve güvensizlik hisleri belirmiş; korkulan şey olmuş, ordu politikaya karıstırılmıștır.

Sayın Vekilim, bu ahval küçümsenecek, cebir ve şiddetle geçiştirilecek şeylerden değildir. Memleket, hükümet ve Partinizin düştüğü bu müşkil vaziyeti kurtarmak için sükunetli, fakat ciddi ve zecri tedbirler almak lazımdır. Bu tedbirler sunlar olmalıdır:

1. Cumhurbaşkanı istifa etmelidir. Çünkü bütün fenalıkların bu zattan geldiği hakkında memlekette umumi bir kanaat vardır. 


\section{Mayıs Sabahı: Asker Yönetimde}

Kara Kuvvetleri Komutanı'nın 13 maddelik mektubunun da bütün öbür uyarılar gibi bugün anlaşılması çok güç bir umursamazlıkla dikkate alınmazken Gürsel'in uzaklaşmasının ihtilalci subaylar arasında yarattığı telaş, daha küçük rütbede olsa da General olan Cemal Madanoğlu'nun gerekli liderliği yapabileceği haberiyle yatıştı ${ }^{38}$ Hazırlıklar tamamlandı ve Türkiye, 27 Mayıs sabahı "..demokrasinin içine düştüğü buhran ve son elim olaylar dolayısıyla, aynı zamanda kardeş kanı dökülmesine meydan vermemek için" ülkenin yönetimine el koyduğu haberiyle uyand.. ${ }^{39}$

2. Kabinede iyi kabul edilmeyen ve suihalleri bütün memlekete yayılmış bulunan zevat çıkartılmalı ve yeni kabine mutlaka dürüst, makul, zorcu değil, adalet ve şefkat hissi taşıyan zevattan kurulmalıdır.

3. İstanbul, Ankara Valileri ve Emniyet Müdürleri süratle değiştirilmelidir.

4. Ankara Örfi İdare Komutanı derhal değiştirilmelidir.

5. Son çıkarılan ve Tahkikat Komisyonları ihdas eden kanun kaldırılmalıdır.

6. Mevkuf gazeteciler bir Af Kanunu ile kısa zamanda tahliye edilmeli.

7. Son hadiselerde tevkif edilen talebeler serbest bırakılmalı, ilim müesseseleri yeniden faaliyete geçirilmelidir.

8. Simdiye kadar çıkarılan bütün antidemokratik kanunlar tedricen kaldırılmalıdır.

9. Vatandaşın hürriyet ve eşit muamele hakkına mutlak surette riayet edilmelidir.

10. Ordunun meseleleri süratle halledilmelidir.

11. Din istismarcılığından vazgeçilmelidir.

12. Suistismaller oluyor mu bilmiyorum. Fakat olduğu hakkında umumi bir kanaat

mevcuttur ve milletin hükümete karşı itimatsızlığına sebep olmaktadır. Bu gibi kötülüklerin şiddetle bertaraf edilmesi lazımdır

13. Müstesna zamanlar ve günler haricinde hükümet büyüklerinin memleket gezilerinde sun'i büyük vatandaş toplulukları ile karşılanmaları usulü terkedilmelidir.

Muhterem Vekilim, bu yazdıklarım asla bir parti ve politika mülahaza ve tesiri ile yazılmamıștır. Memleketin durumunun bu tedbirlerin alınmasını zaruri kıldığına inandığım için arz edilmiştir. Sizlerin vatanperverlik ve vicdanlarınıza hitap ediyorum. İyi düşününüz iyi hareketler yapınız. Memlekette çok şeyler yaptığınız muhakkaktır. Fakat bu, asla kafi değildir. Bu yapılan işleri müstemleke idarecileri de yapar, yapıyor ve yapmıştır. Asıl mühim olan toplumun ruhunda yaşama zevk ve azminin geliştirilmesi, hak ve hürriyet aşkının kökleștirilmesi, vatandaş idrakinin yüksek ve necip hislerle donatılmasıdır. Olaylar bu yolda olmadığınızı göstermektedir.

Talebelerin hürriyet duygusu ile yaptıkları masumane tezahürata karşı kıtalar sevkedilmesi ve onların desteği ile emniyet kuvvetlerinin ilim yuvalarının içine kadar girerek talebeleri, profesörleriyle beraber joplarla ve kurşunlarla tedip etmesi, dünyada görülmemiş feci bir şeydir. O hengamede kız talebelerin yürekler parçalayan çı̆̆lıklarının, analar, babalar ve halk ruhunda onulmaz yaralar açacağını ve actı̆̆ını anlamamak, memleketin huzuru bakımından büyük bir hata ve hazin bir gaflet olduğuna kaniim. Bizim gençlerimizde hak, adalet ve hürriyet duygularının gelişmesinden ve kemalinden memnun olmanız lazım gelmez mi? İstikbali hissiz, duygusuz, müstemleke ruhlu yalnız maddeci bedbaht insanlara $\mathrm{m}$ birakmak istiyoruz?

Sayın Vekilim, maruzatım muhakkak ki çok mühim ve hatta çok cürretkaranedir. Fakat memleket için, milletin selameti için, Hükümet ve hatta partinizin kurtarılması için dikkate alınması lazımdır ve hatta çok lazımdır. Saygılarımla,

3.5.1960

$$
\text { Kara Kuvvetleri Komutanı }
$$

Orgeneral Cemal Gürsel"

${ }^{38}$ İpekçi, Abdi, Ömer Sami Coşar, İhtilalin İçyüzü s. 150-158.

${ }^{39}$ Kurucu Meclis'in seçtiği Anayasa Komisyonu'nun 20 üyesinden biri de olan Prof. Dr. Mümtaz Soysal, Anayasaya Giriş (Ank. 1968) kitabında 27 Mayıs Rejimi olarak adlandırılabileceğini belirttiği dönemin a) Milli Birlik Komitesi'nin yönetime el koyduğu 27 
Radyodan yayınlanan ihtilal bildirisiyle hareketin hiçbir şahıs veya zümreye karşı olmadığı, ülkenin temel düzenine, dış politikasına bir değişiklik getirilmeyeceği NATO'ya CENTO'ya bağlılık sözleriyle Ankara'dan gelecek mesajları merakla bekleyen dünyaya duyuruldu. Bildiri metni hazırlanırken yabancı ülkelerin, özellikle ABD'nin ikili anlaşmaları öne sürerek askeri yönetime karşı tavır almamalarını sağlamak için bu açıklamalara yer verilmesi kararlaştırılmıştı. ${ }^{40}$

Duyarlı vatandaşların büyük çoğunluğu, ordunun yönetime el koymasını son yıllarda Türk devriminden verilen ödünlerle sarsılmaya çalışılan Atatürkçülüğün zaferi olarak gördüler. Yönetime el koyanlarsa bir askeri dikta kurmak heveslisi olmadıklarını en kısa zamanda seçime gidileceğini hemen duyurarak ${ }^{41}$ belli ettiler ve karşı ihtilal olmadan cuntaların gitmediğini düşünenleri rahatlattılar. Böylece kamuoyunun desteğini kazanan hareketle ülkenin yönetimini üstlenen Milli Birlik Komitesi'ni (M.B.K.) üç önemli görev bekliyordu. Harekete hukuksal dayanak sağlamak, en önde gelen zorunluluktu. İkincisi, iktidarın, boşluklardan yararlanarak Anayasayı askıya alması ülkeyi bu noktaya getirdiğinden, devletin başındakilere halka baskı yapma olanağı tanımayacak yeni bir anayasa hazırlanmasıydı. Üçüncüsü de "Anayasayı ihlal” ile suçlanarak göz altına alınan devletin en üst makamlarını da içeren kimselerin vakit geçirmeden yargılanıp cezalandırılmalarıydı. 27 Mayıs sabahı Cumhurbaşkanı, Başbakan, kabine üyeleri ve D.P.nin önde isimleri göz altına alınırken Milli Birlikçilerin düşündüğü, hukukun üstünlüğünü önde tutacak bir anayasanın geçmiş dönemin yanılgılarının tekrarlanmasını önleyeceğiydi. Bildikleri de bunu kendilerinin hazırlayamayacağıydı. Her ikisinin de alt yapısı ancak köklü hukuk bilgisi 1 şı̆̆ında hazırlanabileceğinden konunun uzmanlarına danışmak kaçınılmaz bir gereksinimdi. Komitenin büyük bir sağduyu göstererek Madanoğlu'nun hemen o sabah hukuki konuları danışmak üzere Ankara'ya çağırdı ̆̆ İ̀stanbul Üniversitesi Hukuk Fakültesi profesörlerinin önerilerine uyarak derhal bir anayasa ve seçim yasası hazırlanmasına yönelmesi, 27 Mayıs'ın kimliğini darbe'den ihtilal'e; 1,5 yıl ve üç komisyonun çalışmaları sonunda

Mayıs gününden anayasa değişikliği için ilk çalışmaların geçici Anayasanın duyurulması ile sonuçlanan 12 Haziran'a kadar b) Milli Birlik Komitesi'nin 12 Haziran'da geçici Anayasanın duyurulmasından başlayarak 12 Temmuza kadar geçici yasalar, bu tarihten sonra kanunlar yayınlayarak yasama organı görevini yürüttü̆ğ̈̈, 6 Ocak 1961'de Kurucu Meclis'in işbaşına getirilmesine kadar ve c) Kurucu Meclis'in Anayasa ve seçim yasası hazırlamak başta, yasama organı olarak 25 Ekim 1961'de yapılan seçimle yönetimi devretmesine kadar olmak üzere üçe ayrılabileceğini yazmaktadır.s. 145-148.

${ }^{40}$ Küçük, Sami, a.g.e. s. 89.

${ }^{41}$ Milli Birlik Komitesi üyelerinden Kamil Karavelioğlu, Bir Devrim Íki Darbe, 27 Mayls, 12 Mart, 12 Eylül (İst. 2007) kitabında "Yönetime ihtilalle gelmek, sonra da yönetimi seçimle devretmek, 3000 sene evvel ancak Kartaca'da olmuştur" satırlarıly gerçekten uygulanan bu sözün önemini vurgulamaktadır. s. 62 . 
referandumla kabul edilen 1961 Anayasası'nın kurumsal içeriği de bu kimliği inkılap'a çevirdi.

İlim Heyeti olarak adlandırılan hukukçular grubu, hemen çalışmaya başladı. İlk adım olarak iktidarın meşruiyetini (yasallığını) kaybettiğini anlatan ve komite üyelerinin adlarının halka açıklanmasını, bir hükümet kurulmasını, sorumluların gözaltına alınmasını ve onları yargılamak üzere yüksek bir yargı organı oluşturulmasını, ayrıca yeni Anayasa çalışmaları süresince geçerli olacak geçici Anayasa yapılmasını öngören bir rapor hazırlandı. Devlet kuruluşlarından uzmanların ve Milli Birlik Komitesi'nin kuracağı hükümetin süzgecinden geçtikten sonra yürürlüğe girecek olan yeni bir Anayasa ve seçim yasası 1şı̆̆ında seçim yapılarak yönetimin devredileceğini de içeren ve 28 Mayıs'ta yayınlanan bu rapor ${ }^{42} 27$ Mayıs'ın hukuksal dayanağı oldu. ${ }^{43}$

\section{İhtilale İlişkin Birkaç Saptama}

Gerek bu dayanağı oluşturan İlim Heyeti'nin görevlendirilmesi, gerekse o sabah erken saatlerde yaşananlar, Silahlı Kuvvetlerin yönetime el koyması kararını verenlerin bu önemli adımı attıktan sonrası için pek de hazırlıklı olmadıklarını düşündürmektedir. Örneğin, hareket o sabah radyodan duyurulurken, hatta günün ileri saatlerinde yapılan duyurularda bir lider adı geçmemişti. Askeri kanattan belli kimselerin bir süredir lider olarak düşündükleri Cemal Gürsel'in adı, Orgeneral'in o gün saat 11'de Etimesgut Havaalanına inen C-47 Çubuk 6024 uçağıyla $^{44}$ apar topar İzmir'den getirilmesinden sonra duyurulmuştu. Bir şaşkınlık da Gürsel gelene kadar ihtilalin lideri durumundaki General Cemal Madanoğlu sabah erkenden karargah yapılan Harp Okulu'na geldiğinde önceden belirlenmiş 74 kişi yerine gözaltına alınmış yüzlerce D.P.'liyle karşılaşması üzerine yaşanmıştı. $\mathrm{Bu}$ kalabalığın gözaltına almalar başladığında asıllı asılsız ihbarların değerlendirilmesiyle bir yandan da D.P.'ye tepkili sıradan vatandaşların kendiliklerinden bildikleri, buldukları D.P.'lileri tam anlamıyla derdest edip Harp Okulu'na getirmeleriyle oluştuğunu öğrenen Madanoğlu, odalara sığmayan yüzlerce kişinin bir kısmını serbest bıraktırmış, belediyeden istenen 28 otobüsle evlerine dönmelerini sağlamıştı. Ne var ki İlim Heyeti

${ }^{42}$ Feridun, Dr. Server, Anayasalar ve Siyasal Belgeler, İst. 1962, s.65-68. Rapor Başkan İstanbul Üniversitesi Rektörü Ord. Prof. Sıddık Sami Onar ve Üye İstanbul Hukuk Fakültesi Dekanı Ceza Hukuku Prof. Naci Şensoy, Üye İstanbul Hukuk Fakültesi Medeni Hukuk Ord. Prof. Hıfzı Veldet Velidedeoğlu, Üye İstanbul Hukuk Fakültesi Anayasa Prof. Hüseyin Nail Kubalı, Üye İstanbul Hukuk Fakültesi İdare Hukuku Prof. Ragıp Sarıca, Üye İstanbul Hukuk Fakültesi Anayasa Prof. Tarık Zafer Tunaya, Üye İstanbul Hukuk Fakültesi İdare Hukuku Doçenti İsmet Giritli tarafından imzalanmıştı.

${ }^{43}$ Aydemir, Şevket Süreyya, a.g.e., s.386-387.

${ }^{44}$ Elevli, Avni, a.g.e., s.94. 
geldiğinde bunun yargı kanalıyla yapılması gerektiğini hatırlatınca, aynı kimseler tekrar gözaltına alınmışlardı. ${ }^{45}$.

İhtilal sonrasının yeterince planlanmadığının bir başka göstergesi de İlim Heyeti'nin saptanma yöntemidir. Askeri harekatın yasallığa dayanması gerektiği daha önce konuşulmuş, hatta Cemal Gürsel'in yeni bir Anayasa gerektiğine çok önceden işaret etmiş olmasına karşın ilk gün bu konuda da bir boşluğa düşülmüştü. İhtilale hukuksal dayanak sağlamak için önerilerine başvurulan İlim Heyeti de Madanoğlu'nun bir süre önce bir dost evinde tanıdığı bir profesöre başvurması ve onun önerdiği yedi İstanbul Üniversitesi Hukuk Fakültesi öğretim üyesinin hemen Ankara'ya getirilip anayasa hazırlamakla görevlendirilmesiyle oluşmuştu ${ }^{46}$.

D.P.'nin on yıllık iktidarı boyunca hükümetin gitgide demokrasiye, anayasaya sırt çevirerek yasallıktan uzaklaşıp merkeziyetçi bir yönetime dönüşmesi, ulusal sorumluluk bilinci ve duygusu taşıyan her vatandaşta ve elbette Silahlı Kuvvetler'de bu gidişi durdurmak gereğini körüklemiş, girişimleri başlatmıştı. Askerlerin birkaç yıla yayılan hazırlıklarına temel oluşturarak eyleme geçiren, ulusal egemenlik bilincinin, bağımsızlık kıvancının örselenmesi, cumhuriyetin temel ilkelerinin çiğnenmesi, Atatürk sevgisinin yok edilmeye çalışılması karşısında kabaran duygulardı. Milli Birlikçilerden Suphi Karaman yıllar sonra bu gerçeği şu sözlerle dile getirmiştir: "Aslına bakılırsa 8 ay önce bile tam teşekkül etmiş bir ihtilal komitesinden pek de bahsedilemez. Sonra ne yapabilirdik ki? Biz bir şey okumamıştık, bir şey bilmiyorduk ki bizden ekonomik, sosyal işler, reformlar beklensin". ${ }^{47}$ İşte 27 Mayıs'ı gerçekleştiren genç subaylar, Türkiye Cumhuriyeti tarihinin bu önemli dönemecini ev toplantılarında gizlice örgütlenerek hazırlarken hedefleri, laiklik yönü başta gelmek üzere D.P. yönetiminin zamanla daha çok gözardı ettiği Atatürkçü değerlere dönmekti. Nitekim bu husus, Orhan Erkanlı'nın Ankara'daki ilk örgütlenme sırasında

${ }^{45}$ Küçük, Sami, a.g.e. 105, Karavelioğlu, Kamiil, a.g.e. s. 47-48 Sami Küçük, baştan tüm D.P. ileri gelenlerinin potansiyel suçlu görüldüğü bir yaklaşımla gözaltına alınmaların Komite'nin yanlış bir uygulaması olduğunu yazmakta, "baştan yargı yoluyla yapılsa idi Yassiada Mahkemelerinin o kadar uzamaz, toplumun acıma duyguları da o kadar artmazdı" yorumunu yapmaktadır..

${ }^{46}$ Adı Nedim Ergüven olan bu profesörün önerdiği kimseler; İstanbul Üniversitesi profesörleri Sıddık Sami Onar, Naci Şensoy, Hüseyin Nail Kubalı, Hufzı Veldet Velidedeoğlu, Ragıp Sarıca, Tarık Zafer Tunaya, İsmet Giritli ve Muammer Raşit Sevig idi. Aydemir, Şevket Süreyya, İhtilalin Mantığı, s. 379; Karavelioğlu, Kamil, a.g.e. s.51, İpekçiCoşar, a.g.e., s.253.

${ }_{47}$ Aydemir, Şevket Süreyya, İhtilalin Mantı̆̆, s. 487 . Milli Birlikçilerle 27 Mayıs’1 izleyen günlerde yapılan çeşitli söyleşilerde hangi kitapları okudukları sorulduğunda genel yanitın Fin yazar Grigori Petrof'un "Beyaz Zambaklar Memleketinde" olduğunu ve bunun aydınlar arasında eleştirilerini ve Askeri lise ve Harp Okulu öğrencilerine ders kitapları dışında kaynaklar için sıkı bir okuma yasağı uygulandığının konuşulduğunu annesi tarih öğretmeni babası tarih profesörü olan bu satırların yazarı hatırlamaktadır. 
ortaya koyduğu 20 maddelik esaslar, ${ }^{48}$ sonra da Milli Birlik Komitesi'nin 1960 Eylül'ünde yayınladı̆̆ 1 Direktifler arasında yer almıştı. ${ }^{49}$ D.P. iktidarının Atatürk inkılaplarına düşman duruma düşmesi İlim Heyeti'nin 28 Mayıs bildirisinde 27 Mayıs hareketinin meşruluk nedenleri arasında gösterilmişti ${ }^{50}$.

27 Mayıs'1 hazırlayan subaylar üniformalarla ihtilal hazırlıkları yapmanın ciddiyetinin bilincinde olarak not tutmamaya, yazılı belge bulundurmamaya çok dikkat ettiklerinden, tüm ayrıntıların belleklere yazılması $^{51}$, kuşkusuz bir takım hazırlıksız yakalanmalara ve yukarıda da değinildiği gibi, bazı noktaların sonradan düşünülmesine yol açmıştı. Ne var $\mathrm{ki}$, ihtilalin üzerinden yıllar geçtikten sonra geriye bakıldığında, Silahlı kuvvetlerin yönetime el koymasından sonra, ilerleyen aylarda ülkede sosyal, kültürel ve ekonomik yaşamı yükseltecek bir girişim, topluma yansıyacak olumlu bir yenilik getirilememesi, yönetimi ele almış olanları da huzursuz etmişti. Bu huzursuzluk, kilit noktalarındakilerden aşağıya doğru büyüyerek yurt sevgisinin ülkenin yükselmesi için yeterli olmadığı anlaşıldıkça orduda ileride anlatılacak bölünmelere bile yol açacaktı.

Üzerinde durmak gereken bir başka nokta da eylemin herhangi bir siyasal bağlantıya yer vermeden gerçekleştirildiğidir. Aslında 27 Mayıs aşamasında genel kanı, Halk Partisi'nin ve İnönü'nün bu eylemle bağlantısı olduğuydu. İnönü'nün Tahkikat Komisyonu yasalaşırken yaptığı uyarıcı konuşmada “..Eğer bir idare İnsan Haklarını tanımaz, baskı rejimi kurarsa o memlekette ayaklanma olur. Buna meydan vermemek için idarelerin demokratik yolda olması, İnsan Haklarının yürürlükte olması şarttır. Eğer İnsan Hakları yürütülemez, vatandaş hakları zorlanırsa, ihtilal behemehal olur" ${ }^{52}$ diyerek bir ay sonraki ihtilale vize verdiği bile söylenmişti. Oysa umudunu ve beklentisini seçim yapılmasına bağlamış olan İsmet Paşa'nın da hareketi herkes gibi sabah radyodan duyana kadar yine herkes gibi tahminden öteye bir bilgi sahibi olmadığı anlaşılmaktadır. Bu yönde birçok saptama yapabiliyoruz:

28 Mayıs sabahı Paşa'yı arayan Cemal Gürsel'in “Size karşı kusurluyuz Paşam. Hareketimizi size önceden haber vermedik Fakat haber verseydik biz bundan caydırmak isteyeceğinizi biliyorduk. Fakat yapacak başka bir şeyimiz kalmamıştı. Bizi affetmenizi rica ediyoruz. Emirleriniz bizim için daima Peygamber buyruğudur Sayın Paşam" ${ }^{\text {"53 }}$ açıklaması, bu saptamalardan biridir. $\mathrm{Bu}$ görüşmeden bir gün sonra İnönü'nün Yakup Kadri

\footnotetext{
${ }^{48}$ Aydemir, Şevket Süreyya, a.g.e. , s.395.

${ }^{49}$ Dr. Server Feridun, Anayasalar ve Siyasal Belgeler, İstanbul 1962, s. 82-85.

${ }^{50}$ Özek, Çetin, Devlet ve Din, İst. 1979 s. 488.

${ }^{51}$ Sami Küçük'le 2008 Temmuzunda yapilan görüşme.

${ }^{52}$ T.B.M.M. Zabıt Ceridesi, 27 Nisan 1960, Devre XI, Cilt:I3 İçtima 3, s.301.

${ }^{53}$ Aydemir, Şevket Süreyya, Ihtilalin Mantığ , s.374.
} 
Karaosmanoğlu'na "Kurmayları, Kurmay Albayları bilirim. Bunlar gelir ama gitmesini bilmezler" demesi, Temmuz başında Cumhuriyet Gazetesi'nde yer alan bir söyleşideki "Seçimlerin bir an önce yapılmasında sayılamayacak kadar çok milli menfaat vardır" ${ }^{\prime 54}$ sözleri, onun askeri bir harekete taraftar olmadığını anlatmaktadır. Kaldı ki İnönü, D.P. iktidarının baskısından bunalan C.H.P. yerel örgütlerinin, üyelerinin ve yandaşlarının coşkuyla karşıladığı 27 Mayıs'ın ve askeri yönetimin seçim sandığı başında partiye zarar verebileceğini bile düşünmüştü. İhtilali izleyen günlerde parti örgütlerini duygusal taşkınlıklara meydan verilmemesi ve sükunetin korunması yolunda uyardığ 1 telgrafından sonra 20 Haziran'da il ve ilçe başkanlıklarına bütün kademelere ulaştırılması kaydıyla bu doğrultuda bir genelge göndererek C.H.P.'nin ihtilali hazırlayıp uygulayan "idealistlerle aynı görüş ve düşüncelerle aynı inanca sahip" olmakla birlikte ordunun eyleminde C.H.P.'nin rolü olduğuna yönelik gerçek dişı propagandadan kesin olarak sakınmalarını, yönetime güvenerek seçime kadar sükunetin korunmasını istemişti. ${ }^{55}$ İnönü seçimin en kısa zamanda yapılacağına inandığı için bu süreyi tanımlamamıştı. Oysa izleyen haftalarda İlim Heyeti Başkanı Prof. Sıddık Sami Onar, "Seçimleri çabuk yapmak kadar hatalı bir is olmaz. Meselenin bitaraf bir hükümet ve bitaraf bir idare elinde halledilmesi lazımdır" ${ }^{\prime 6}$ derken, Prof. Hüseyin Nail Kubalı da Alparslan Türkeş’le görüşmesinde Onar'a katıldığını, Yassıada duruşmaları sonuçlanıp hükümler infaz edilmeden yönetimin sivil bir iktidara bırakılmasının doğru olmadığını, askerin en az bir buçuk yıl iktidarda kalması gerektiğini,"57 söylemişti.

\section{Güç Ama Gerekli İşlev: İhtilalin Gerekçelendirilmesi}

M.B.K. de en kısa zamanda seçime giderek yönetimi sivile devretmekte kararlıydı. Ama 27 Mayıs ihtilalinin temel gerekçesi, iktidarın anayasayı çiğneyerek gayrımeşru duruma düşmesi olduğundan, ilk andan beri benzeri ortamın gelişebileceği boşlukları olmayan yeni bir anayasa hazırlanmasını zorunlu görmekteydi. Kaldı ki bu gereği Sadi Kocaş, bir askeri harekat olasılığını Cemal Gürsel ile paylaşırken de dile getirmişti. Hatta hazırlanacak yasanın Anayasa mahkemesi, planlama örgütü gibi kurumlarla çift meclisli parlamento, üniversite muhtariyeti, yargı teminatı gibi uygulamalara yer vererek, üniversite hocalarının yardımıyla hazırlanabileceğini açıklamıştı. ${ }^{58}$ Anayasadan sonra ikinci önemli noktanın seçim olduğunu 27 Mayıs'ın ilk saatlerinde Harp Okulu'ndaki kısa konuşmasıyla harekete yeşil ışık yakarken Madanoğlu ihtilal kadrosunun siyasal görev almak yönünde hiçbir beklentisi

\footnotetext{
${ }^{54}$ Aydemir, Şevket Süreyya, İkinci Adam, Cilt III, s.493-94.

${ }^{55}$ Kili, Suna, 1960-1975 Döneminde C.H.P.'nde Gelişmeler, İst. 1976, s.136-138

${ }^{56}$ Aydemir, Sevket Süreyya , a.g.e., Cilt III s.495.

${ }_{58}^{57}$ Aydemir, Şevket Süreyya, İhtilalin Mantı̆̆gl.. s. 425.

${ }^{58}$ Koçaş, Sadi, a.g.e. s. 457.
} 
olmadı ̆̆ının altını çizerek belirtmişti. Ne var ki uzmanların eline bırakılsa da yeni bir anayasanın hazırlanmasının ve seçime gidilmesinin sanıldığı kadar kolay ve çabuk olamayacağ 1 çok geçmeden anlaşıldı. İlim Heyeti Genelkurmay Başkanlığı'na taşınan karargahta Madanoğlu'nun yanına gittiklerinde İzmir'den gelerek kendilerine katılan Cemal Gürsel de "Biz Üniversiteye inanıyoruz.Yalnız inanmıyoruz, iman ediyoruz. Sizi davet etmemizin sebebi budur" diyerek profesörlerden elverdiğince kısa zamanda 'dinin istismarına olanak vermeyecek ve ihlal edilemeyecek bir anayasa hazırlamalarını rica' edip üç ay içinde seçime gidip iktidarı bırakacaklarını, sonra da askerlerin hiçbir görev kabul etmeyeceklerini söylemişti. ${ }^{59}$ Bununla birlikte, 27 Mayıs'ın ilk saatlerden beri İhtilal Komitesi yasa niteliğinde numaralı bildiriler yayınlarken Silahlı Kuvvetlerin amacının anayasal düzen içinde yasallık ve demokrasi olduğu, 28 Mayıs raporuyla gerekçelendirilmiş de olsa duygular durulduktan sonra pek kabul görmeyebilirdi. Bu bakış açısıyla hocaların önerisi bakanlarının belirlendiği bir hükümetin kurulması ve Milli Birlik Komitesi'nin adının resmileştirilerek üyelerinin halka duyurulmasıyd $1 .{ }^{60}$ M.B.K., artık Anayasa Komisyonu olarak anılacak İlim Heyeti'nin iki önerisine de uydu. Ancak, hükümet kurulurken Alparslan Türkeş ve dokuz kişilik grubu hükümette askere de yer verilmesini isteyip amaçlanan düzenlemelerin uzun sürede yapılabileceğini öne sürerek Milli Savunma, Ulaştırma ve İçişleri bakanlıklarına talib olması üzerine ilk anlaşmazlıklar ortaya çıktı. Madanoğlu'nun çok sert tepkisi üzerine Gürsel'in Devlet Başkanı, Başbakan, Milli Savunma Bakanı ve Silahlı Kuvvetler Başkomutanı, Türkeş’in Başbakanlık Müsteşarı olmaları, iki bakan dışında hükümetin sivillerden oluşmasında uzlaşıldıysa da ${ }^{61}$ İkinci sorun M.B.K. üyeleri belirlenirken yaşandı.

Sayısal ağırlık küçük rütbeli subaylarda olmak üzere üsteğmenden generale kadar uzanan ve kendiliğinden katılımlarla gitgide kabaran Milli Birlik Komitesi'nin belli bir sayıda tutulması ve bazı isimlerin üyeliği çevresinde sert tartışmalar yapıldı. Sonunda Komitenin kesin şeklini belirlemek üzere oluşturulan seçici kurul, 11 Hazirana kadar süren çekişmeli çalışmalar sonunda çoğu Kara Kuvvetleri'nden 38 kişinin "Milli Birlik Komitesi Üyeleri" olarak açıklanmasını karara bağladı. ${ }^{62}$ Kamuoyu

${ }^{59}$ Karavelioğlu, Kamil, a.g.e., s. 46, İpekçi-Coşar, a.g.e., s. 255.

Avni Elevli, değinilen yapıtında 28 Mayıs günü Orgeneral Cemal Gürsel'i Genelkurmay Başkanlığı’nda ziyaret eden İlim Heyeti üyesi Prof. Dr. Hüseyin Nail Kubalı'nın hazırlanacak geçici anayasanın geçerli olabilmesi için bir meclis tarafından tartışılıp onanması gerektiğini, dolayısıyle, "ihtilal karargahının isimlerinin bilinmesine zaruret" olduğunu hatırlattığını yazmaktadır. s. 105.

${ }^{61}$ İpekçi-Coşar, a.g.e., s. 261.

${ }^{62}$ İpekçi-Coşar, a.g.e., s.300. Seçici Kurul, Cemal Madanoğlu'nun başkanlığında, Ekrem Acuner, Suphi Karaman, Sami Küçük, Sezai Okan, Alpaslan Türkeş, Orhan Erkanlı, Orhan Kabibay ve Ahmet Yıldız'dan oluşmuştu. 
M.B.K.'ni oluşturan isimleri 14 Haziran'da Resmi Gazete'de yayınlanan Geçici Anayasa ile öğrendi.

\section{Geçici Anayasanın Işs̆̆̆ında}

Milli Birlik Komitesi'nin kabul ettiği 1 sayılı 27 maddelik “1924 tarih ve 491 sayılı Teşkilatı Esasiye Kanununun bazı hükümlerinin kaldırılması ve bazı hükümlerinin değiştirilmesi hakkında geçici Kanun”, başlığından da anlaşılacağı gibi, Cumhuriyetin ilk anayasası olan 1924 Teşikilatı Esasiye Kanunu esas alınarak hazırlanmışı.$^{63} 5$ sayfalık kısa ama özlü metinde yasanın hazırlanış nedenleri, yasama-yürütme-yargı organlarının dengesi, M.B.K.'nin, Devlet Başkanı'nın ve Bakanlar Kurulu'nun yetki ve görevleri belirlenmişti.

Dört bölümden oluşan bu yasanın ilk bölümü olan Genel Hükümler kısmında M.B.K.'nin, Türk Ordusu'na Teşkilatı Esasiye Kanunu ile verilmiş olan Türkiye Cumhuriyetini kollamak ve korumak görevi doğrultusunda hareket ederek geçici olarak yönetimi ele aldığ 1 açıklanmıştı. İlk madde "Yeni Anayasa ve Seçim Kanunu demokratik usullere uygun olarak kabul edilip buna göre en kısa zamanda yapılacak olan genel seçimlerle yeniden kurulacak olan Türkiye Büyük Millet Meclisine iktidarı devredeceği tarihe kadar" yasama yetkisinin Milli Birlik Komitesi'nde olduğunu, 3. Madde de yürütme yetkisini Devlet Başkanının atayacağı, Komitenin onaylayacağı Bakanlar Kurulu'nun sürdüreceğini belirlemişti. (Madde 3) , ancak, Komite'nin Bakanları denetleme ve görevinden çıkarmaya yetkili olduğu (Madde 4) yasama ve yürütme yetkileri olarak belirlenmişti. Tarafsız mahkemelerin "kanun sınırları içinde millet adına" yargı hakkını kullanacakları da belirtildikten sonra eski yöneticilerin soruşturmaları belli esaslarla kurulacak Yüksek Soruşturma Kurulu tarafından tamamlandıktan sonra "adli, idari ve askeri kazaya mensup hakimler arasından" kurulacak arasından" kurulacak Yüksek Adalet Divanı'nda yargılanacakları izleyen maddelerde belirtilmişti. Yasalarla ilgili müzakerelerin gizli yapılacağı ve kararların yayınlanmayacağı (Madde 15) ve "İdam kararlarının infazı, kararın Mili Birlik Komitesi'nce tasdikine bağlıdır" maddeleri, bu belgenin ihtilal yasası olduğunun bir hatırlatmasıydı. Genel seçimlerle kurulacak T.B.M.M.'nin görevine başlamasıyla Mili Birlik Komitesi’nin hukuki varlığının son bulacağının altının çizilmesi de o tarihe kadar Komitenin tam yetkili olduğuna vurgulamaydı. İlgili hükümleri ve üyelerin adlarının ilk kez açıklanmasıyla ${ }^{64}$ M.B.K. de bu yasayla resmen

${ }^{63}$ T.C. Milli Birlik Komitesi Kanunlar Dergisi Cilt 43, 1961, s. 1-3 , 27 maddelik 1 No.lu geçici yasa (Resmi Gazete ile ilanı:14.6.1960-say1 10525)

${ }^{64}$ Bu yasayla açıklanan Milli Birlik Komitesi Başkanı Cemal Gürsel'in altındaki komite üyelerinin adları şöyleydi: Ekrem Acuner, Fazıl Akkoyunlu, Refet Aksoylu, Mucip Ataklı, İrfan Baştuğ, Rifat Baykal, Emanullah Çelebi, Ahmet Er, Orhan Erkanlı, Vehbi Ersü, Numan Esin, Suphi Gürsoytrak, Orhan Kabibay, Kadri Kaplan, Mustafa Kaplan, Suphi Karaman, 
kurulmuş oluyordu. Herhangi bir siyasal partiyle ilişkisi olmayan öğretim üyesi ve deneyimli bürokratlardan 15, Milli Birlik Komitesi'nden de 2 üye ile böylece kurulan yeni hükümet de resmiyet kazanan Milli Birlik Komitesi'nin yerleşmiş olduğu Meclis binasında (bugün müze olan İkinci Meclis) 21 Haziran'da görevine başladı.

Burada dikkat çeken bir nokta, 27 Mayıs'a İhtilal kimliği kazandıran yeni Anayasa çalışmaları çarçabuk başlatılırken, yargılamaları gerçekleştirmek üzere kurulan Yüksek Adalet Divanı ile Yüksek Soruşturma Kurulu'nun çalışmalarına da aynı kimliği kazandırmak üzere süre belirleme veya çabukluk ilkesinin getirilmemiş olmasıdır. ${ }^{65}$ Gürsel'in önerisiyle Yassıada'da yapılması kararlaştırılan duruşmalar çok uzayıp genelde 27 Mayıs hareketini, özelde de Milli Birlik Komitesi'ni çok yıprattı. Aslında bu yıpranmada gerek Anayasa Komisyonu üyeleri arasındaki anlaşmazlıkların gerekse Komite üyelerinin iç çekişmelerinin büyük payı oldu. Hatta bu iki etken, tarihi değişikliklere bile yol açtı: Komisyon üyelerinin içerikle ilgili bazı konularda anlaşmazlıklarından dolayı uzayan tartışmalar yüzünden Anayasa'nın gecikmesi Kurucu Meclis oluşturulmasıyla; askerlerin anlaşmazlıkları da ileride değinilecek 14'ler olayı ve ilk Milli Birlik Komitesi'nin dağılmasıyla sonuçlandı.

\section{Yürürlüğe Giremeyen Anayasa Tasarıları: İstanbul Komisyonu}

27 Mayıs günü İstanbul'dan Ankara'ya çağırılan hukuk profesörleri bir gün içinde hazırladıkları rapordan ve resmilik kazanan Geçici Anayasa'dan sonra, asıl Anayasa metnini hazırlamaya odaklandılar. Ankara Üniversitesi öğretim üyelerinden Prof. Dr. İlhan Arsel, Prof. Dr. Bahri Savcı, Doç. Dr. Muammer Aksoy ve Doç. Dr. Vakur Versan'ın da katılımıyla 10 kişiye ulaşan Anayasa Komisyonu, toplumu çağdaş, yönetimi demokratik, devleti güvenilir yapacak bir Anayasa hazırlamayı amaçlıyorlardı. D.P. iktidarının

Muzaffer Karan, Kamil Karavelioğlu, Osman Köksal, Münir Köseoğlu, Fikret Kuytak, Sami Küçük, Cemal Madanoğlu, Sezai Okan, Muzaffer Özdağ, Fahri Özdilek, Mehmet Özgüneş, Salahattin Özgür, Şükran Özkaya, İrfan Solmazer, Şefik Soyuyüce, Dündar Taşer, Haydar Tunçkanat, Alparslan Türkeş, Sitkı Ulay, Ahmet Yıldız, Muzaffer Yurdakuler.

${ }^{65}$ Sevket Süreyya Aydemir, Menderes'in Dramı kitabında (İst.1993, s.454-455) bu konuyu Milli Birlik Komitesi'nin içine düştüğü bir çelişki olarak tartışmakta, hatta devlet başkanından sokaktaki adama kadar 512 sanığın mahkemesini yapmakla görevli hakimler kadrosunun da "klasik hukuk anlayıșından ve normal yargı kademelerinden gelen" kimseler olduklarından, Yassıada Mahkemelerinin ihtilal mahkemesi sayılamayacağını öne sürmekte ve "27 Mayıs İhtilalinin ve getirdiği iktidar organının bence en çelişmeli ve ihtilali köstekleyen konusu, Yassıada davaları sistemidir"demektedir. Enver Ziya Karal'ın notlarında okuduğumuza göre de (s.141) duruşmaların İhtilal Mahkemeleri şeklinde yapılması, sık sık gündeme gelen bir konu olmuștu. Nitekim, 1 Mart 1961 günü Madanoğlu'nun Kurucu Meclis üyelerinin bazılarını konuk ettiği öğle yemeğinde de konu açılmış ve orada bulunanlardan Avni Doğan düşüncesini "İnkılap çok nazik oldu. Tedbirler alınmalıdır. Buna lüzum vardır" diye belirtince Karaosmanoğlu bu sözlerin çok belirsiz olduğunu öne sürerek kastedilen Inkılap Mahkemelerine taraftar olmadığını açıklamıştı. İbrahim O̊̉ktem, Emin Paksüt ve Karal da ona katılmışlardı. 
Meclis'te haksız yaptırımları unutulmadığından, çoğunluk partisinin diktatoryasına olanak tanımayacak bir anayasa hazırlanması hedeflenmişti. Girişte bu hedefin belirtildiği oldukça çabuk hazırlanan 6 kısımlık anayasa taslağı 191 madde, "Son Hükümler" başlıklı 6. Kısımdaki 9 ekle de toplam 200 maddeden oluşmuştu. İçeriğe özenle yerleştirilen koruyucu maddelere karşın Anayasanın boşluklarından yararlanarak toplumu baskı altında tutmak isteyen yönetimler olabileceği kaygısı ve kuşkusunun bir türlü giderilemediği Giriş’te duyguları yansıtan satırlarda belirmişti. Tasarıda yürütme, yani hükümet üzerinde denetim mekanizması oluşturacak Millet Meclis'i ve Cumhuriyet Senatosu'nu içeren ikili Meclis sistemine ve yargı bağımsızlığını güçlendirecek Anayasa Mahkemesi'ne yer verilmişti. Üniversite, Radyo-Televizyon ve Haber Ajansı başta gelmek üzere Milli Müze ve Kütüphane ile Opera, Konservatuar, Opera, Merkez Bankası ve İktisadi Devlet Teşekkülleri, özerk kurumlar yapılmıştı. Kamu, kişi, basın özgürlüğüne, sosyal haklar ve güvencelere de oldukça geniş yer verilerek 1924 Anayasası'nda "sınırları kanunla tayin olunur" sözleriyle yasamaya tanınan yoruma açık haklar, açık ve ayrıntılı içeriklerle sıralanmıştı. ${ }^{66}$ Ayrıntılarından dolayı çok uzun olduğu öne sürülerek eleştirilen bu tasarının önde gelen bir özelliği, sosyal veya bireysel hak ve yükümlülükler açısından kişinin temel alınmasıydı. ${ }^{67}$

Anayasa Komisyonu üyeleri, kapsamlı araştırma, incelemelerin yanı sıra değişik görüşler alabilmek için anketlere de başvurdukları 4,5 ay süren çalışmaları sırasında bazı maddeler üzerinde zaman zaman anlaşmazlıklara düştüler. Bunlar ana dil, siyasi partiler, İkili Meclis sistemi, İnönü tarafından ihtilal yapan bir asker grubunun tekrar orduya dönmesinin doğru olmayacağı savıyla ortaya atılan Milli Birlik Komitesi üyelerine İkinci Meclis'te, yani Senato'da ömür boyu senatörlük tanınması, en çok da Anayasayı onaylayacak Kurucu Meclis kurulması üzerindeydi. Askerlerin ilk günlerde yönetimi hemen sivillere devredecekleri sözleriyle çeliştiği gibi Komisyonu da bölen Tabii Senatör unvanıyla İkinci Meclis'e katılmalarını Cemal Gürsel, Anayasa Komisyonu Başkanı Onar ve bir süre sonra 14'ler olayına ve komitenin parçalanmasına yol açacak olan Türkeş grubu da desteklenmekteydi

Anayasa Komisyonu üyeleri arasındaki uyumsuzluklar, zaman zaman tartışma boyutlarını aşan gerginliklerle bir ay gecikmeyle 17 Ekim'de tamamlanabilen Anayasa tasarısı incelenmek üzere Milli Birlik Komitesi'ne sunulduğunda, bu anlaşmazlığın kanıtı olan muhalefet şerhleri de metine

${ }^{66}$ Sarıca, Murat, 27 Mayıs 1960'dan 1961 Anayasasının Hazırlanışına Kadar Geçen Dönemde Anayasa Hareketleri, Cumhuriyet Döneminde Hukuk, İst. 1973, s.74, 86.

${ }^{67}$ Tanör, Bülent, Anayasa Hukukunda Sosyal Haklar, İst. 1978, s. 183. 
eklenmişti. ${ }^{68}$ Bunlar, Komisyon Başkanı olarak ilk imzayı koyan Ord. Prof. Dr. Sıddık Sami Onar başta gelmek üyelerin her birinin onaylamadıkları noktaları gösteren ayrı ayrı hazırlayıp imzaladığ notlard $1 .^{69}$ Komisyonun içindeki çekişme ve anlaşmazlıklar kamu oyuna da yansımış ve daha hazırlanırken tasarının güvenilirliğini sarsmıştı. Böylece, çoğu kez İstanbul Komisyonu olarak anılan heyet tarafından hazırlanan taslak bir bakıma ölü doğmuşsa da özverili çalışmalar boşa giden bir uğraşı olarak kalmadı. Tasarı, içeriği açısından 1961 Anayasası'nı hazırlayan ekip için çok aydınlatıcı oldu. Kurucu Meclis sahneye çıktıktan sonra Temsilciler Meclisi tarafından seçilen Anayasa Komisyonu, neredeyse sürpriz olarak tanımlayabileceğimiz şekilde ortaya çıkıveren Siyasal Bilgiler Fakültesi İdari İlimler Enstitüsü'nün hazırladı ğı Anayasa tasarısından da oldukça yararlandi.

\section{Siyasal Bilgiler Fakültesi Tasarısı}

Anayasa Komisyonu, tasarısını hazırlarken çeşitli kurumların görüşlerini almak üzere bir anket hazırlamış bu arada Siyasal Bilgiler Fakültesi İdari İlimler Enstitüsü'ne de başvurmuştu. Anayasanın güçlü ve gerçek anlamda demokratik olabilmesi için atanan ve kapalı bir komisyon tarafından hazırlanmasını yeterli bulmayan Enstitü öğretim üyeleri, anket sorularına yanıtlarını bağımsız bir Anayasa tasarısı şeklinde hazırlamışlardı. Anayasanın içeriğinin kamu oyunca tartışılmasını gerekli gören bu ekibin gerekçeli olarak hazırladığı tasarıda, bu önemli belgenin ulusun seçeceği bir kurucu mecliste değerlendirilerek oya sunulması öngörülmüştü. İlki gibi toplumun huzur, güven ve gönencini sağlayacak demokratik hukuk devletini sosyal temelleriyle kurmayı hedefleyen bu tasarının daha dar alanlı ve daha iyimser olması ilkine göre önemli farkıydı: ${ }^{70}$

Siyasal Bilgiler Komisyonu, anayasaların sık ve kolay değiştirilmemesi gerektiği yönünde hareketle tasarının siyasal sistemin kalıcı unsurlarını içermesini esas almıştı. Biri geçici olmak üzere 110 maddede toplanan hükümleri kısa, ayrıntısız, genel prensipleri kapsayan bu tasarının ilkinde de görülen ve 1961 Anayasası'na yansıyacak önemli bir özelliği, getirilen yeni kurumlarla 1924 Anayasası'nın T.B.M.M.'nin egemenliğin temsilcisi olduğu görüşünden uzaklaşılmasıydı. Anayasaya daha çağdaş bir kimlik kazandıran

${ }^{68}$ Feridun Server, a.g.e. s.204-205. Kazım Öztürk'ün hazırladığı ve İstanbul, Siyasal Bilgiler Fakültesi İdari İlimler Enstitüsü ve Karal Komisyonlarının tüm Anayasa çalışmalarının görüş̧melerini ve metinlerini içeren 5 ciltlik dev yapıtta, bu muhalefet şerhlerinin, yazarın da belirttiğine göre üçü bulunamadığından, Ord. Prof. Hifzı Veldet Velidedeoğlu, Prof. Dr. İlhan Arsel, Prof. Dr Ragıp Sarıca, Prof. Dr Bahri Savcı, Doç. Dr. Lütfü Duran ve Doç. Dr. Vakur Versan'ınkiler olmak üzere altısı aynen verilmiştir. Bk. Kazım Öztürk, Türkiye Cumhuriyeti Anayasası, İzahl, Gerekçeli, Belgeli ve Maddelere Göre Tasnifli Bütün Tutanakları İle, İș Bankası Kültür Yayınları, İst. 1966 , s.85-338.

${ }^{69}$ Feridun, Dr. Server, a.g.e., s. 204-205.

${ }^{70}$ Sarica, Murat, a.g.m., s.86-87. 
bu değişiklik kuşkusuz Demokrat Parti döneminde Meclis'te sayısal üstünlüğe sahip olmanın verdiği güvenceyle yapılan baskılarla ulusun sindirilmek istenmesinin doğurduğu olumsuzluklar anımsanarak yapılmıştı. Aynı kaygıyla tasarıda yasama da, biri İstanbul Komisyonu'nun Senato olarak adlandırdığı Cumhuriyet Meclisi olan ikili Meclis üzerine geliştirilmiş, yargı organının bağımsızlığı işlenmiş, ancak, ayrı bir uyuşmazlık mahkemesi kurulması öngörülmeyerek Anayasa Mahkemesi daha güçlendirilmişti. İlkinden farklı olarak güçlü bir yürütme organı planlanan ${ }^{71}$ Enstitü tasarısında da sosyal devlet anlayışı getirilmekle birlikte ayrıntılarına girilmeden ele alınan sosyal haklara daha çok "devletin ödevleri” olarak yaklaşılmıştı. ${ }^{72}$

Ana hatlarını özetlemeye çalıştı̆̆ımız her iki anayasa tasarısı da iktidarın anayasayı kullanarak topluma yapılabileceği haksızlıklara tepki olarak hazırlanmanın izlerini taşıyan, özenle hazırlanmış içerikleriyle kuşkusuz büyük emek ürünüydü. Ancak, komisyonlarda ortak noktalarda birleşmekte çekilen zorluklar, dönemin siyasal gelişmelerinin zorlamalarıyla birleşerek Türkiye Cumhuriyeti'nin temel yasası olarak yaptırım kazanacak Anayasa'nın bir kurucu meclis oluşturulmasından sonra seçilecek üçüncü komisyonun elinden çıkmasını gerektirdi.

\section{Milli Birlik Komitesi Puan Kaybediyor: Eminsular Sorunu}

Anayasa tasarısındaki anlaşmazlıklar beklenen belgeyi geciktirirken, Milli Birlik Komitesi de içinden sarsılmaktaydı. Bazı üyelerin daha geniş ve uzun süreli siyasal yetki istemelerinden kaynaklanan bu huzursuzluğa biraz da söz verildiği gibi ülkenin iyi gitmeyen sosyoekonomik durumunu ve siyasetini düzenleyecek reformlara bir türlü el atamamak yol açıyordu. Böylece, Komite içinde halka sunacak yenilikler peşinde koşan gözler, orduya ve üniversiteye yöneldi ${ }^{73}$. Önceki yönetimin askeri güce gerek gösteren bağlayıcı anlaşmalarının da oynadığı rolle Silahlı Kuvvetlerin ekonomiyi zorlayacak kadar çok büyüdüğüu, Üniversitelerde de yeni bir yapılanma gerektiği her ortamda sıkça tartışılan konular olduğundan bu iki kurumda da daraltma yapılması kararlaştırıldı. Komite'nin 2 Ağustos tarihli ve 42 sayılı yasayla 235 'i general çoğu da yüksek rütbeli yaklaşık 5000 Silahlı Kuvvetler üyesini emekliye ayırmaları, ${ }^{74} 27$ Ekim'de de hiç beklenmeyen ve gerekçesi hiç anlaşılmayan 114 sayılı yasayla 147 öğretim üyesini işten almaları ${ }^{75}$ kamu oyunu hem şaşırttı, hem ürküttü, çok da küskün yarattı. Üstelik iki girişim de Milli Birlik Komitesi'nin sarsıntılarını ancak derinleştirdi.

\footnotetext{
${ }^{71}$ İbid s.86-105

${ }^{72}$ Tanör, Bülent, a.g.e., s.183,

${ }^{73}$ Kamil Karavelioğlu ve Sami Küçük'le 2008 Temmuzu'nda yapılan görüşmeler,

${ }^{74}$ T.C. Milli Birlik Komitesi Kanunlar Dergisi, Cilt 43, 1961, s.56-57 Kanun No. 42,

${ }^{75}$ T.C. Milli Birlik Komitesi Kanunlar Dergisi, Cilt 43, 1961, s. 56-57, s. 266.
} 
Ordudaki kabarıklığı gidermek ve orduyu gençleştirmek için alındığı öne sürülen emeklilik kararı, Genel Kurmay'da adları saptanan subayların yanı sıra emekliliği gelmiş olsun veya olmasın kendi isteğiyle ayrılanlara iki kat ikramiye ödeneceği sözü verilerek uygulanmıştı. Çoğundan emekli olmak istediklerini bildiren dilekçeler alınmıştı. ${ }^{76}$ Hazinede yeterli fon olmadığından emekliye sevk edilenlere verilen sözü karşılayacak ödeneği NATO yardımıyla karşılamak yoluna başvurulmuş, Ankara'ya davet edilen NATO'nun Amerikalı Başkomutanı Orgeneral Norstadt'ın oluruyla gerekli fon sağlanmıştı. ${ }^{77}$

25 Ağustos'ta kamuoyuna isim listeleriyle birlikte açıklanan emeklilik kararı, işlemler ve ödemeler bakımından düzenle uygulanmışsa da büyük şaşkınlıkla karşılandı Öte yandan, her ne kadar Alparslan Türkeş emekli edilenlerin kendi grubuna muhalifler olduğunu açıklamışsa $\mathrm{da}^{78}$ bu kararın nasıl neden ve kimler tarafından verildiği hiç kesinlik kazanmadı. Uygulama genç, nitelikli, deneyimli 5000 subayı hiç alışı olmadıkları ve beklemedikleri bir yaşama itilirken yıllarca en uzak yurt köşelerine de uzanarak yerine özverili hizmetlerin böyle bir haksız kararla son bulmaması gerektiğini düşünüyordu. ${ }^{79}$ Eminsu'lar (Emekli İnkılap Subayları) olarak anılacak bu subaylarla ihtilal aşamasında çağırılmayan, eylem başarıyla sonuçlandıktan sonra da görev verilmeyen ve bunun kırgınlığını taşıyan yüzlerce subaydan sonra, orduda ikinci bölünmeyi yaratılmıştı.

Komutanlarının, arkadaşlarının, meslektaşlarının yüz yüze kaldığı bu durum, orduda kalanları da üzdü. Bir süre sonra, yaratılan küskünlüğü hiç değilse hafifletecek ödünler düşünüldü. Emekli edilenlerin pek çoğunun dinç, sağlıklı, bilimsel nitelikli kimseler olduğu ve ülkeye de hizmet edebilecekleri dikkate alınarak isteyenlere öğretmenlik yapabilme olanağı sağlayan bir yasa çıkarıld ${ }_{1}{ }^{80}$ Emeklilerin maddi sarsıntısını bir ölçüde de olsa önlemek üzere 26 Aralık'ta da ayrı bir yasa çıkarılarak çok uygun koşullarda mesken sahibi olabilmeleri sağlandı. ${ }^{81} \mathrm{O}$ sıralar hazinenin boş olduğu duyulunca halk, yılların baskısından sonra özgürlük havası solumanın coşkusuyla yönetime destek olabilmek için "Hazineye Yardım"

\footnotetext{
${ }^{76}$ İpekçi-Coşar, a.g.e., s. 335-36.

${ }^{77}$ Küçük, Sami, a.g.e., s.112-113.

${ }^{78}$ Enver Ziya Karal'ın özel arşivinden: Kurucu Meclis Notlar1-Amil Artus'un anlattıkları.

${ }^{79}$ Çoğu emekli olmak isteği belirten dilekçe vererek emekli edilen, büyük bir kısmı ya emekliliği hak etmiş, ya da neredeyse 25 yılını doldurmus durumda olan Eminsular hakkında çok kalem oynatılmıştır. Örneğin Cemal Gürsel'e İzmir'den hareketin başına geçirilmek üzere getirilirken eşlik eden son bir yıl boyunca yanında çalışan Kurmay Yarbay Avni Elevli "Batırılamayan Gemi Türkiye, Cilt I" (Ank. 1967) kitabında kendisini içermese de haksız bulduğu bu işlemi eleştirmekte ve emekli edilenlerin ailelerinin 5 kişilik olduğu hesaplandığında ülkede 25000 kişiyi mağdur ve küskün yapan bu uygulama ile ihtilalin de iş görebilecek büyük bir güçten yoksun kaldığını yazmaktadır. ( s.296)

${ }^{80}$ T. .C. Milli Birlik Komitesi Kanunlar Dergisi, Cilt 43, 1961, Kanun No 125 s. 297.

${ }^{81}$ T. .C. Milli Birlik Komitesi Kanunlar Dergisi, Cilt 43, 1961, Kanun No 297 s. 432.
} 
kampanyası başlattı. Kampanyaya akan özverili katkıların en çarpıcısı, yüzbinlerce yurtseverin parmaklarındaki altın evlilik yüzüklerini çıkararak hazineye bağışlamasıydı. Bu kimseler katkılarının karşılığında armağan edilen ince metal halkacıkları parmaklarına takarlarken subay evleri için girişim, hoşnutsuzluk yarattı, söylentilere yol açtı. $\mathrm{O}$ ara yapımına başlanan subay evleri halk arasında "Alyans Mahallesi" olarak adlandırıldı. Bu tepki de Milli Birlikçilerin toplum içindeki saygınlığını örselediyse de asıl karabasanı, adları geçtiğinde insanların hafifçe gülümsediği Eminsuların üzerine düştü.

\section{Puan Kaybı Sürüyor: 147'ler Sorunu}

147'lere gelince, D.P. iktidarının oldukça incittiği, 27 Mayıs sabahı danışılmak suretiyle gönülleri okşanan üniversite öğretim üyelerinin ne gerekçeyle görevlerinden alındığı o kadar anlaşılamamıştı ki, kimi profesörler, 28 Ekim sabahı gazeteleri ellerine aldıklarında uzun listedeki isimleri, o anın heyecanıyla gözlüksüz okuyuvermişlerdi. ${ }^{82}$ Milli Birlikçiler, Atatürk dönemindeki Darülfünun Reformundan beri Üniversitede köklü yenilik yapılmadığını öne sürerek bu kurumda da bazı yenilikler gerektiğini özellikle kadro sıkıntısı çeken bazı arkadaşlarından duymuşlardı. Üstelik, Komitede ordudan tasfiyelerin Silahlı Kuvvetleri çok rahatlattı̆̆ını öne sürerek üniversiteye de benzeri bir uygulama gerektiğini düşünenler vardı. Reform projesini hazırlamayı Yüzbaşı İrfan Solmazer gönüllü olarak üstüne alarak bir profesör yakınının önerileri çerçevesinde gereken listeyi hazırladığında ${ }^{83}$ ülke Cumhuriyet Bayramını kutlamaya hazırlanıyordu. Bilim ve kültür yaşamına indirilen bu darbe en çok askeri çok destekleyip alkışlayan Türk aydınını ve üzdü. Rektörler istifa ederken üniversite öğrencileri ilk tepkilerini Şeref Tribününde Milli Birlikçilerin oturduğu 29 Ekim törenlerine katılmayarak gösterdiler. Milli Eğitim Bakanı Prof. Bedrettin Tuncel, olayı öğrenir öğrenmez Devlet Başkanı'na koştu. Cemal Gürsel'in üzüntülerini belirtip yasayı tekrar inceleyeceği sözü vermesi, o an için yüreklere biraz su serptiyse de iş o kadarla kald1. ${ }^{84}$.

${ }^{82}$ Babam Ord. Prof. Enver Ziya Karal'ın da, sonradan konuştuğu bazı meslektaşları gibi, hem kendisinin listede olup olmayacağı hem de kimlerin olduğu heyecanıyla tüm sayfayı gözlüksüz okuduğuna tanık olmuş, hatta ben hatırlatmıştım. Üniversitelerin resmi ve sorumlu organlarına bilgi verilmeksizin çıarılan 114 Sayılı Yasa üzerine Ankara, İstanbul, İstanbul Teknik, Orta Doğu Teknik ve Ege üniversitelerinin rektörlerinin hemen istifa etmelerinden, olayın öğretim üyeleri, öğrenciler, kamu oyunda yankılarının, gösterilen tepkilerin, Üniversite senatoları, Milli Birlik Komitesi, Bakanlık yetkilileri ve ilgili kurulların açılamaları ve olayla ilgili yerli ve yabancı basından makalelerin yer aldığ 1 Beyaz Kitap, 147'ler Mes'elesi (Ist. 1962) 147'ler olayının ayrıntıları için baş vurulabilecek bildiğimiz en geniş kapsamlı yayındır.

${ }^{83}$ Küçük, Sami, a.g.e. s. 114, Karavelioğlu, Kamil, a.g.e., s. 74.

${ }^{84}$ Üniversitelerinden ayıklama yapılmamış Ege ve ODTÜ rektörleri, Sami Küçük'ün ODTÜ için bulduğu istifaların mütevelli heyet tarafından kabul edilmemesi formülüyle, Ege'de de aynı kararı Senato'nın almasıyla unvanlarını korudular. 
En üzücü ve şaşırtıcı nokta da hocaların "görevden affedilme" nedenlerine bir türlü açıklık getirilmemesiydi. Görevden alınanlar için ortada dolaşan masonluk, komünistlik söylentilerinin yanı sıra o sıralar yine hızla çalışan kulak gazetesinde, iki çarpıcı başlık bilimsel yetersizlik ve Demokrat Parti'ye yakınlık idi. Ancak, 28 Ordinaryüs Profesörün bulunduğu ve asistanlara kadar uzayan listede yer alan öğretim üyelerinin pek çoğu, araştırmaları ve yayınlarıyla dünyaca tanınmış, Türk ve yabancı üniversitelerde dersler vermiş, uluslararası bilim kurullarından ödüller almış, öğrencileri ve meslektaşları tarafından sevilen ve sayılan kimselerdi. Yine pek çoğu, 28 Nisan'la gelişen üniversite olaylarında hükümete karşı tavır almış, Menderes'in öğretim üyelerini hedef aldığı Turgutlu nutkunu açık imzalarla protesto etmişlerdi. Üstelik, listedekilerden Cahit Talas Milli Birliğin ilk kabinesinde, 27 Mayıs günü Milli Birlik Komitesi tarafından İstanbul'dan çağırılan, Anayasa Komisyonu'nda görevlendirilen, daha sonra da Kurucu Meclis Anayasa Komisyonu üyesi olan üyesi Prof. Dr. Tarik Zafer Tunaya başta gelmek üzere Abdülhak Kemal Yörük, Münir Aktepe, İsmet Giritli Milli Birlik Komitesi'nin onayladığı Temsilciler Meclisi'nde yer almışlardı.

Saygınlığı zedelenen meslektaşlarına arka çıkan hocalar, bildiriler ve makalelerle yasanın ilime, akademik anlayışa ve Türk üniversitelerine darbe vurduğuna, insan haklarına aykırı olduğuna dikkat çektiler, ilgili makamlara dilekçeler gönderdiler. Üniversitelerin sorumlu kurulları Milli Birlik Komitesi'ne, Devlet Başkanına, Milli Eğitim Bakanı'na bu haksızlığın giderilmesi için yazılı başvurular ve ziyaretler yaptılar. Türlü yazışmalarla ilgili makamlara bu yasa ile yaratılan büyük boşluğun birkaç gün içinde yeni öğretim yılına başlayacak üniversitelerde öğrenimi aksatacağı bildirildi. Rusya ve İngiltere'de üniversitelerde on öğrenciye bir öğretim üyesi, Türkiye'de ise 75 öğrenciye bir öğretim üyesi düşerken bu çok farklı oranın 147'ler üniversiteye dönemezlerse 100 'e çıkabileceğine bile dikkat çekildi. ${ }^{85}$ Üstelik 114 No.lu Yasa çerçevesinde bir daha üniversitelerde görev alamayacaklarının da belirtilmesiyle 147'ler sadece görevlerinden çıkarılmakla kalmamış, mesleklerinden de yoksun bırakılmışlardı. Dahası, bu cezaya suçlarının ne olduğunu bilemeden, savunma hakkı da verilmeden çarptırılmışlardı. ${ }^{86}$ Milli Birlikçilerden Muzaffer Karan'ın 2 Kasım tarihli Yeni Sabah gazetesinde yer alan "Ahlaki, ilmi ideolojisi yönünden yüz kızartıcı notlara sahip olan, bilhassa çoğu komünist ve mason, kifayetsiz, cinsi sapık, Kürt devleti kurmak isteyen, asistanlarını metres olarak kullanan, doçentin yazdığı kitaba imzasını koyan, senede 3-5 kere fakülteye gelen üyeleri affettik” (çıkardık) sözleri, bir çok profesörü, eşlerini ve çocuklarını

${ }^{85}$ Beyaz Kitap, 147ler Mes'elesi, s.337: Ord. Prof. Dr. Reşat Kaynar'ın 28 Mart 1961 tarihli “147'ler Ne İstiyorlar” makalesi.

${ }^{86}$ İbid. ,Prof. Reşat Kaynar, 147’ler ve Haksızlık, s. 344-345. 
hem üzmüş, hem de zor durumda bırakmıştı. Muzaffer Özdağ'ın 29 Ekim tarihli Dünya Gazetesi'ndeki "Bu operasyonu Üniversite yapamazdı. Zira şimdiye kadar kendi kalbi ve beyni üzerinde operasyon yapan hasta görülmemiştir... Bu hareket tarihe 27 Mayıs devriminin en müsbet eseri olarak geçecektir" sözleri, boşta kalan kürsüler için de 30 Ekim tarihli Akşam Gazetesi'nde yer alan "Asistanlar doçent, doçentler profesör olur" yanıtı, şaşkınlık ve Komite için genel kaygıyla karşılanmıştı. Bununla birlikte düşüncesi, Milli Birlik Komitesi'ne İstanbul Üniversitesi Edebiyat Fakültesi'nden çekilen aşağıdaki telgraftan da anlaşılacağı gibi Üniversitenin içinden bile destek görmüştï. ${ }^{87}$ :

"Biz İstanbul Üniversitesi Edebiyat Fakültesi üyeleri ve yardımcıları Milli Birlik Komitesinin esasen Üniversite camiasının yüzde 99.9 nisbetinde teklif ettiği şekilde çıkardı̆̆ 1 yeni Üniversiteler kanununa tamamen ve yapılan tasfiyeyi prensip olarak desteklediğimizi bildiririz. Aflılar (çıkarılanlar) arasında bugün hak ve hürriyetten bahsedenler tıpkı yıllarca milletin sesini boğmak isteyen düşük iktidarın başları gibi eski Üniversiteler kanununun antidemokratik hükümlerini daima kendi lehlerine ve daha şiddetli surette tatbik etmişler ve diğer tatbikçiler karşısında hürriyetten yoksun öğretim üyeleri ve yardımcılarının ızdıraplarına kulaklarını tıkamışlardı. Bu gün bu gerçeği hatırlatmak mecburiyetindeyiz. Üniversitelerimize hürriyetin sıcak güneşini getiren bu kanunu, sayın Milli Birlik Komitesinin dilediği gibi Türk ilim ve irfanı bakımından milletimiz için hayırlı be başarılı olacağına şüphemiz yoktur.

Ord. Prof. Ahmet Erdal -- Prof. Sırrı Erinç, Prof. Ali Nihat Tarlan, Prof. Ahmet Ateş

Doçent Dr. Semavi Eyice, Doçent Dr.Necdet Tunçbilek, Doçent Dr. İsmail Tuanlı, Doçent Dr. Halil İnalcık, Doçent Dr. Nurettin Sadi Kösemihal, Doçent Dr.Tahsin Yazıcı, Doçent Dr. Cahit Tanyol, Doçent Dr. Faruk Timurtaş, Doçent Dr. Erol Tümertekin -- Ast.Dr. Zengin Ormanll, Ast.Dr. Bekir Küçükoğlu, Ast.Dr. Necmettin Hacı Eminoğlu, Ast.Dr. Bedriye Denker, Ast.Dr. Muammer Kemal Üzergin, Ast.Dr. Nihat Çetin, Ast.Dr. Turgut Bilgin, Ast.Dr. Acun Kurter."

$\mathrm{Ne}$ kamuoyundan, öğrencilerden, yabancı üniversitelerden gelen tepkiler, ne iç ve dış basında yer alan düzinelerce makale ve yorum, ne olaya kendisine yapılan başvuru ve ziyaretlerden sonra ağır hastalanan ve bu yüzden soruna yeterince eğilemeyen Gürsel'in bile kararın geri alınacağını söyleyip $^{88}$ "zararın neresinden dönülse fazilettir" şeklinde yaklaşması, 147'lerin seçimler yapılıp demokratik düzen yerleşene kadar üniversiteye dönmelerini sağlayamadı. Geri dönüş, 1961'den sonra İnönü’nün

\footnotetext{
${ }^{87}$ İbid., s. 486-487.

${ }^{88}$ Hürriyet, 2 Kasim 1960
} 
Başbakanlığında kurulan C.H.P.-AP Koalisyon Hükümeti döneminde gerçekleşti.

Bir türlü yanıtlanmayan soru işaretleriyle bu uygulamanın da M.B.K.'nin ve 27 Mayıs hareketinin kamuoyunun büyük çoğunluğunun gönlündeki yerini önemli biçimde etkilediğini söylemeliyiz. Eminsu'lar gibi, ișten el çektirilen öğretim üyelerinin hangi kıstaslarla saptandığına yönelik sorular, hocalar görevlerine döndürülürken de giderilmedi. Üstelik bu olumsuzluklara bir de Milli Birlik Komitesi'nin içinden sarsılmasının ürünü olan ve Cemal Gürsel'in Komite toplantılarını "artık muharebe meydanını andırır hale gelmişti" sözleriyle tanımladığı ve, "biz de yapılması gerekeni yaptık" ${ }^{\prime 89}$ diyerek açıkladığ 14 'ler olayı eklendi:

\section{Milli Birlik Komitesi’nin Üçüncü Sorunu: 14'ler}

Milli Birlik Komitesinin Milli savunma, tarım, iskan-mesken, sosyal ve sağlık, mali, ticari, sanayi, bayındırlık, köy kalkınması, ulaştırma, iç-dış siyaset işlerinde tasarılarını kapsıyan ve yönetimi en geç 1961 yılı sonbaharında yeni iktidara devredeceğini bildiren 16 maddelik programı 16 Eylül tarihli Resmi Gazete'de yayınlandı̆̆ında, ${ }^{90}$ Komite içindeki ciddi uyumsuzluk zaten başlamış, programın yaptırım kazanması için gereken görüş birliği ve bütüncüllük çoktan sarsılmıştı. Milli Birlik Komitesi'nin parçalanmasına yol açan bu sarsıntı, Alparslan Türkeş'in altında askerin siyasal yaşamda yer almasına ilişkin farklı düşünen bir grubun toplandığı 27 Mayıs hareketinin ilk ayına, hatta bazı varsayımlara göre C.H.P. iktidarının son yıllarına kadar uzanmaktaydı. Ülke yönetimine el koyarken M.B.K.'nin büyük çoğunluğunun hedefi, en kısa zamanda uygun ortamı sağlayıp ülke siyasetini sivil yöneticilere bırakmaktı. Oysa Türkeş'in de bulunduğu bir grup, 27 Mayıs'ı getiren siyasal kaosa son vermekten daha kalıcı işler yapmak istediklerini öne sürerek ülkenin özellikle ekonomik durumunu düzeltecek kalıcı önlemleri sistemleştirmek, birkaç yıldan önce tamamlanama olasılığı bulunmayan bu tasarı gerçekleşene kadar siyaseti elde tutmak istiyorlardı. Türkeş, bunun belki de ilk işaretini 27 Mayıs'tan önce daha Milli Birlik Komitesi oluşurken vermiş, ${ }^{91}$ Cemal Gürsel'in yardımcısı olmakla da bu emeli doğrultusunda daha emin adımlarla yürüyebileceğini düşünmüştü. Anayasa hazırlıkları başarısızlıkla sonuçlanıp yeni deneyimin Kurucu Meclis çatısı altında yapılacağını kesinleşince bu yöntemi hiç desteklemeyen Türkeş anayasa çalışmalarının Başkan Yardımcısı ve Müsteşarlık görevlerinden çekilmeye karar verdi. Hemen kabul edilen 23 Ekim tarihli istifa mektubundan sonra ${ }^{92}$ Anayasa'nın daha

${ }^{89}$ Aydemir, Şevket Süreyya, Íhtilalin Mantı $\breve{g} \iota$ s.409. Beyaz Kitap, 147ler Mes'elesi, İst. 1962, s.5.

${ }^{90}$ Feridun, Dr. Server, Anayasalar ve Siyasal Belgeler, İst. 1962 s.82-90.

${ }^{91}$ Küçük, Sami, a.g.e., s.79.

${ }^{92}$ Karavelioğlu, s. 93. 
geniş bir yapı içinde hazırlanmasının kararlılığıyla Gürsel, Türkeş grubunun karşı koyacağını bilerek Komite'nin tüm üyelerinin onayını almadan, 31 Ekim günü o zaman ODTÜ Rektörü olan Turhan Feyzioğlu'ndan bir komisyon kurarak 20 gün içinde Kurucu Meclis tasarısı hazırlamasını istedi. ${ }^{93}$ Bu gelişmeler, Milli Birlik Komitesi için uzun süredir "geliyorum" diyen büyük bunalımın son habercileriydi. Türkiye, 12 Kasım günü Komite'nin 14 üyesinin kıdem durumuna bakılmaksızın en üst dereceden emekli edilerek yurt dışında görevlendirildikleri ve ardından, Milli Birlik Komitesi'nin lağvedildiği haberiyle sarsıldı. Eminsulardan ve 147'lerden sonra bu üçüncü şok haberdi.

Alınan karara göre Alparslan Türkeş Yeni Delhi, Orhan Kabibay Brüksel, Orhan Erkanlı Mexico City, Münir Köseoğlu Stockholm, Mustafa Kaplan Lizbon, Muzaffer Karan Oslo, Şefik Soyuyüce Kopenhag, Fazıl Akkoyunlu Kabil, Rifat Baykal Tel Aviv, Dündar Taşer Rabat, Numan Esin Madrid, İrfan Solmazer'e Lahey, Muzaffer Özdağ Tokyo, Ahmet Er Trablusgarp büyükelçiliklerinde elçilik danışmanı olarak atanmışlardı. Bu gelişmeyi 13 Kasım günkü demeciyle duyuran Cemal Gürsel, özetle 14'lerin, ülkenin bir süre partisiz yönetilmesi ve sonra seçimlere gidilmesinde direnmelerinin, Milli Birlik Komitesi'nin "anayasa kabul edilir edilmez seçime gidilerek demokratik düzene dönülmesi hedefiyle" çelişmesinin, ülke için doğurduğu tehlike göz önüne alınarak yurt dışında görevlendirildiklerini açıklamaktaydı.$^{94}$

14'ler grubunun bir karşı hareketle kendileri gibi düşünmeyenleri kendi deyimleriyle "paketleyerek" çalışmaların yürütüldüğü İkinci Meclis binasının alt katındaki koridorlarda göz altına almak üzere olduklarının duyulması, olayı tetiklemişti. Nitekim karardan birkaç gün önce, 9 Kasım'da Alparslan Türkeş'in yaptığ ${ }_{1}$ Konya ziyaretinde, kendisini hiçbir generalin karşılamaması, çevresine toplanan küçük rütbeli subayların kendisine "hayatınızdan endişeniz varsa korumaya hazırız" demelerinin Devlet Bakanı'na, onun kanalıyla da Gürsel'e yansıtılması, geri sayımı başlatmıştı. ${ }^{95}$ Kamuoyuna kararın duyurulması ani olmakla birlikte, Milli Birlik Komitesi içinde son aşamaya (iki gece sabaha kadar süren son umut görüşmelerinde anlaşmazlık çözülemeyince) gelinmiş, 2 Kasım gecesi Madanoğlu'nun oturmakta olduğu Cumhurbaşkanlığı Genel Sekreteri konutunda yapılan toplantıda Sitkı Ulay, Ekrem Acuner, Fikret Kuytak, Sami Küçük, Osman Köksal, Sezai Okan, Mucip Ataklı, Haydar Tunçkanat, Emanuel Çelebi, Refet Aksoyoğlu, Suphi Gürsoytrak, Vehbi Ersü, Şükran Özkaya tarafından alınan karar, yaveriyle Gürsel'e ulaştırılmıştı. ${ }^{96}$

\footnotetext{
${ }^{93}$ Karakaya, Nihat, a.g.e., s. 298.

${ }^{94}$ Beyaz Kitap,Prof. Reşat Kaynar, 14'ler ve 147'ler, s. 340.

${ }_{95}^{95}$ Enver Ziya Karal'ın özel arşivinden: Amil Artus Anlatıyor.

${ }^{96}$ Küçük, Sami, a.g.e., s 117-118.
} 
14'ler gözlerden uzaklaşmakla gönüllerden uzaklaşmamış, yaklaşık iki yıl sonra ülkeye döndüklerinde özellikle Türkeş, çevresinde toplanan yandaşlarıyla, özlemini duyduğu siyaset sahnesinde bir süre için de olsa baş rol oynama olană̆ını bulmuştu. Öte yandan bu üç şok olayın her birinin nedenleri konusunda tartışmalar, hep sürdü. Ne var ki, Milli Birlik Komitesi, hatta Türk Silahlı Kuvvetleri, hele Yassıada mahkemelerinin ${ }^{97}$ ve üçü uygulanan 15 idam cezalarını da içeren kararlarından sonra halkın gözünde eski yerini bulamad1.

\section{Kurucu Meclis}

14ler olayından sonra yeniden oluşturulan 23 üyeli Milli Birlik Komitesi, temel ilkelerinde ilkinden farklı değildi: Yeni bir anayasa ve seçim yasası doğrultusunda en kısa zamanda seçimlere gidilerek normal düzene dönülecekti. Kurucu Meclis'in kurulmasında birleşilmiş olması tek farktı. 13 Aralı'ta onanan 12 Haziran tarihli ve 1 No.lu geçici yasaya 157 Sayılı ek yasayla, yine Anayasa ve seçim yasası hazırlamakla görevli bir Kurucu Meclis oluşturuldu. Bu meclis, Orgeneral Cemal Gürsel başkanlığındaki Milli Birlik Komitesini, ayrıca, üyeleri 158 sayılı yasaya göre saptanan Temsilciler Meclisini içeriyordu. Yasada yönetim görevinin en geç 29 Ekim 1961 tarihinde Türkiye Büyük Millet Meclisi’ne devredeceği belirlenmişti.

Temsilciler Meclisi Seçimi Kanunu gereği 10 kişilik kontenjanla Devlet Başkanı başta gelmek üzere siyasi partiler ve türlü kurum ve kuruluşlar belli sayıda üye ile Kurucu Meclis'te temsil edileceklerdi. Temsilciler Meclisi 29 Eylül'de kapatılan Demokrat Parti üyeleri ve destekçilerine kapalı tutulmuştu. Siyasal parti olarak C.H.P.'ye sayısal üstünlüğe sahip olduğundan 49, Cumhuriyetçi Köylü Millet Partisi’ne 25 üyelik tanınmıştı. Milli Birlik Komitesi'nden 18, her ilden en az bir kişinin katılımıyla bütün illerden toplam 75, barolardan, öğretmen, esnaf, tarım kuruluşlarıyla işçi sendikalarının 6'şar, basın kuruluşları, üniversiteler ${ }^{98}$ ve yargı organlarından

${ }^{97}$ Yassıada Mahkemelerinde Cumhurbaşkanı, Başbakan, Meclis Başkanı, bakanların ve Tahkikat Komisyonu üyelerinin bazılarını kapsayan 15 idam cezası verilmiş, Milli Birlik Komitesi'nden Cemal Gürsel, Fahri Özdilek, Sttkı Ulay, Sami Küçük, Osman Köksal, Suphi Karaman, Suphi Gürsoytrak, Selahattin Özgür ve Kamil Karavelioğlu'nun olumsuz oylarına karşılık, Mucip Ataklı, Muzaffer Yurdakuler, Fikret Kuytak, Ekrem Acuner, Sezai Okan, Vehbi Ersü, Kadri Kaplan, Haydar Tunçkanat, Akmet Yıldız, Refet Aksoyoğlu, Mehmet Özgünes, Şükran Özkaya ve Emanullah Çelebi idamların infazı için oy kullanmıs, Adnan Menderes, Fatin Rüştü Zorlu, Hasan Polatkan'ın cezaları yürürlüğe konulurken Celal Bayar'ınki yeni Anayasa gereği yaş haddinden olmak üzere gerisinin ömür boyu hapse çevrilmişti. Ayrıca 30 kişiye müebbet, 304 kișiye 4-20 yıl arası hapis cezası verilirken, 47 kişi beraat etmiş, (Kamil Karavelioğlu, a.g.e. s. 142) mahkum olanlar hapis cezalarını çekmek üzere Kayseri ve Adana cezaevlerine gönderilmis, dört yıl sonra bağışlanarak tutukevlerinden çıkarılmış, Celal Bayar da Cumhurbaşkanlarına Tabii Senatörlük hakkı tanınmasından sonra ölümüne kadar bu unvanla Cumhuriyet Senatosu'nda yer almıştı.

98 Ankara Üniversitesi'nin Kurucu Meclis'e önerilecek temsilcileri pek cok aday arasından 28 Aralık günü saptanırken Rektör Suut Kemal Yetkin “Üniversitemiz Atatürk'ün inkılapçı şahsiyetinin eseridir. Bir kadın temsilcinin üniversiteden seçilmesinin uygun 
12'şer, Eski Muharipler Birliği’nden 2 ve gençlik kesiminden bir üyenin bulunduğu Temsilciler Meclisi ${ }^{99}$ Kurucu Meclis'in seçimleri izleyecek yeni dönemi geniş tabanlı bir yapı içinde hazırlamasına olanak sağlamaktaydı. Milli Birlik Komitesi'nin dikensiz gül bahçesi yaratmak için Demokrat Parti düşüncesinin Meclis'e girmemesi için aldığı önleme karşın, dolaylı temsilcileri "bağımsızlar kategorisinden" Meclise girmişti. Zaten seçim yasası tamamlandıktan sonra yeni siyasal partilerin kurulmasına yeşil 1 şık yakıldı ̆̆ında hemen aynı paralelde hem de iki parti kuruluverecekti. Üstelik bu partiler, yani 27 Mayıs'ta Erzurum'da III. Ordu Komutanı olan, harekata hemen katılmasa da Genel Kurmay Başkanlı̆̆ı'na getirilen, ama Eminsu'larla da emekli edilen kırgın General Ragıp Gümüşpala'nın A.P.'si ve Ekrem Alican'ın Yeni Türkiye Partisi sadece kurulmakla kalmayacak, Anayasayı destekleseler de 1961 seçimlerinde C.H.P.'nin karşısına çok güçlü rakipler olarak çıkarak aydının umduğu ezici çoğunlukla iktidara gelmesini engelleyecekleri.

Yukarıda açıklanan oluşumla, Kurucu Meclis 6 Ocak 1961 günü uzun süren yapımı yeni tamamlanan bugünkü Meclis binasında, hasta olduğundan açılış törenine katılamayan Devlet Başkanı ve Başbakan Orgeneral Cemal Gürsel'in General Fahri Özdilek tarafından okunan söyleviyle açıldı. ${ }^{100}$ Söylevde "Bugün İhtilal Hükümetinin tek gayesi teminatlı bir demokratik nizam içinde, hakka, adalete, hürriyete, eşitliğe ve fazilete dayanan İkinci Cumhuriyeti kurmaktır." diyerek Kurucu Meclis'in amacını açıklayan Gürsel, değişik siyasal eğilimlerde üyeleriyle Kurucu Meclisin çalışmalarını yüreklendirerek "İkinci Cumhuriyeti kurma gayretleriniz sırasında meseleleri, partileriniz bakımından değil, milli menfaatler yönünden tetkik edeceğiniz şüphesizdir...sizlerin İkinci Cumhuriyeti kurma gayretleriniz sırasında meseleleri partiniz bakımından değil, milli menfaatler yönünden tetkik edeceğiniz şüphesizdir" sözleriyle demokrasinin doğal bir parçası olan siyasal farklılıkların ulusal bütünlüğü bozan ayrılığa dönüşmemesi gerektiğini özenle vurgulamıştı ${ }^{101}$.

Burada bir ayraç açarak Gürsel'in bu kısa açış söylevinde iki kez söz ettiği "İkinci Cumhuriyet" kavramı üzerinde biraz durmalıyız. Fransa ve İtalya gibi bazı ülkelerde tarihsel örneğini gördüğümüz anayasanın yürürlükten kaldırılmasından sonra yeni bir anayasa yapıldığında ve/veya yönetim biçiminin değişmesinden sonra tekrar cumhuriyete dönüldüğünde cumhuriyete numara verilmesi, 27 Mayıs'ı izleyen dönemde Türkiye'de de

olacağını” DTCF Profesörlerinden Afet İnan'ı da önermiş, Afet Hanım'ın danıştı̆̆ İsmet Paşa'nın "Hizmettir kabul et” deyince Prof İnan üyelik beklerken Pamukçoğlu'nun Rektörün sözlerine Propaganda maiyetinde görerek İnan'ın adaylığına itiraz etmesi sonunda Ankara Üniversitesi'nin kadın temsilcisinden vaz geçilmişti. Enver Ziya Karal'ın özel notları s. 180 ${ }^{99}$ Kili, Suna , a.g.e. s. 165

${ }^{100}$ T.C. Kurucu Meclisi Tutanak Dergisi, Cilt 1.(6 Ocak- 10 Mart 1961) s.2,3

${ }^{101}$ Kazım Öztürk, a.g.e. s XC-XCI 
benimsenmişti. Ancak, 1961 Anayasası'yla kurulan Türkiye Büyük Millet Meclisi için kullanılan İkinci Cumhuriyet sözü, Türkiye'de zamanla Atatürk'e ve onun getirdiği çağdaş düzene karşı olanların bir söylemi haline gelmiştir. Bilindiği gibi, Atatürkçülüğe karşıt olanların bir kısmı, kulluk yerini alan yurttaşlığı, ümmetin yerini alan ulusu benimseyemeyen, laik Türkiye Cumhuriyeti'ni özümseyemeyen gericilerdir. Bir kısmı da Kurtuluş Savaşı'nın Türklerin yanı sıra Lazlar, Çerkezler, Kürtler, Gürcüler gibi değişik halklar içeren Misak-1 Milli sınırlarını getirdiği için antiemperyalist bir niteliği olmadığını öne süren; yetersizlikle suçladıkları Atatürk'ün zorlamalarla topluma bazı yüzeysel değişimler dayatmaktan öteye gitmediğini tekrarlayan Türkiye Cumhuriyeti'nin ulusal sinırlarıyla, yöneticisi ve yönetim biçimiyle, Anayasasıyla, eğitim ve hukuk sistemiyle, iç ve diş politikasıyla, hatta para birimiyle yepyeni bir devlet düzeni ve anlayışını içerdiğini göz ardı ederek Türk Devrimi'ne devrim denemeyeceğini öne süren, kendilerine göre çok ilericiler'dir. Biri ümmetçi biri etnik ayrımcılığa sarılan bu iki grup, bütüncül (üniter) Türk devletine karşı olmakta birleşmişlerdir. Şu farkla ki gericiler, anayasa yerine şeriat öngörmektedirler. Öbür grupsa 1924 Anayasası'nda gereken demokratik niteliklerin bulunmadığını ve bu niteliklere ancak Atatürk'ün kurduğundan başka bir cumhuriyette ulaşılabildiği noktasından hareket edenlerdir. İşte bu grubun , İkinci Cumhuriyet sözüne sahip çıkmasıyla bu terimden vaz geçilmiştir. Günümüzde İkinci Cumhuriyetçilik, tıpkı gericik gibi, ya Cumhuriyetin duyurulmasıyla ekonomik, kişisel, veya aile çıkarları zedelenenlerin veyahutta emperyalist çıkarlarını sona erdiren Atatürk'e kin besleyen dış ülkeler tarafından desteklenenlerin akımı olmuştur. Dolayısıyle, 27 Mayıs'ı izleyen yasaların, haberlerin veya yapıtların pek çoğunda İkinci Cumhuriyet sözü geçmişse de sonra bu deyim, heveslilerine bırakılmıştır.

\section{Devrimci Meclise Devrimci Anayasa}

Açılış töreninden hemen sonra Meclis çalışmaları başlatıldı ve Anayasayı ve seçim yasasını hazırlayacak komisyonlar seçildi. Anayasayı hazırlayacak 20 üyelik Temsilciler Meclisi Anayasa Komisyonu ${ }^{102}$, C.H.P.'den 10, milletvekillerinden 5, bağımsızlardan da 5'er üye olmak üzere gizli oyla seçilmişti. İlk toplantısını 10 Ocak günü en yaşlı üye olan General Sadık Aldoğan'ın başkanlığında yapan bu komisyon, o gün biri Hıfzı Veldet Velidedeoğlu olan iki aday arasından 12 oyla Ankara Üniversitesi Dil ve Tarih Coğrafya Fakültesi öğretim üyelerinden Türk İnkılap Tarihi Enstitüsü'nün de kurucusu ve müdürü olan Ord. Prof. Enver Ziya Karal'ı başkan seçti. ${ }^{103}$ Emin Paksüt'ün Başkan Vekili, Coşkun

\footnotetext{
${ }^{102} \mathrm{Bu}$ noktadan sonra Anayasa veya Komisyon olarak anılacaktır.

${ }^{103}$ Enver Ziya Karal Kurucu Meclis'e İnönü'nün önerisi ile seçilmiști. Karal, 27 Aralık günü Ferit Melen'in çağrısıyla gittiği Anadolu Kulübü'nde Melen, Kurucu Meclis'e C.H.P.'den adayı olmasını için İnönü'nün önerisini iletmekle görevlendirildiğini söylemişti.
} 
Kırca'nın Yazman, Muammer Aksoy, Turan Güneș, Tarık Zafer Tunaya'nın sözcülüğe seçildiği komisyonun öbür üyeleri Sadık Aldoğan, Nurettin Ardıçoğlu, Amil Artus, Doğan Avcıoğlu, Hazım Dağlı, Münci Kapani, Ragıp Sarıca, Bahri Savcı, Sait Celal Siren, Mümtaz Soysal, Cafer Tüzel Hıfzı Veldet Velidedeoğlu, Abdülhak Kemal Yörük'tü. Enver Ziya Karal'ın Başkan seçildikten sonra "Aranızda herhalde Başkanlığa en az layık olan ben'im. Ne hukukçu ne de siyaset adamıyım. Böyle mümtaz bir heyetin Başkanlığının taşıdığı manaya müdrikim. Benden tarafsızlık bekliyorsunuz. Vaad ediyorum. Bütün memleketin gözü Komisyonumuza çevrilmiştir. Kardeşlik havası içinde çalışarak vaktinde Anayasa'yı bitireceğimize inanıyorum. Bu inan ile çalışmalarımıza başlıyoruz." ${ }^{104}$ şeklindeki kısa konuşmasından sonra Komisyon, önce yabancı ülkelerin anayasalarını incelediği, hukukçu öğretim üyelerinin daha önce hazırlamış olduğu birinci ve ikinci anayasa taslaklarını da değerlendirdiği yoğun bir çalışma dönemine girdi. Kısa bir zamana sığdırılan çok yoğun çalışmalar sırasında Komisyon üyeleri arasında görüş farkları ve tartışmalar olduysa da üyelerin çoğunun bir çok kez vurguladığ 1 gibi Komisyon Başkanı Karal'ın birleştirici kişiliğ i İstanbul Komisyonu'ndaki kopmaya meydan vermedi ve iki ay içinde taslak ortaya çıtı. ${ }^{105}$

Yabancı anayasaları ve özellikle Fransız Anayasası'yla baskı rejimlerine son vermek üzere İkinci Dünya Savaşı'ndan sonra hazırlanan İtalyan ve Alman anayasalarını inceleyen ve 1924 Anayasası'ndan, ayrıca Onar ve Siyasal Bilgiler tasarılarından yararlanan Anayasa Komisyonu, hazırlık döneminin elverdiğince kısa olması için işbölümü yaparak çalıştı. "Başlangıç, genel hükümler ve temel haklar"; "Yasama, yürütme organları ile bunlar arasındaki ilişkiler"; "İdare, iktisat ve maliye ile ilgili hükümler" ve "Yargı organları ve Anayasa Mahkemesi" konularındaki maddeleri

"Eğer bundan parti faaliyetleri için bir fayda umuluyorsa memnuniyetle kabul edeceğini" bildiren Karal, 30 Aralık günü Hukuk Kurumu'nda C.H.P.'nin 49 üyesinin seçilmekte olduğunu öğrendikten sonra akşam eve gittiğinde İnönü'nin şahsına ayrılan 6 kişilik kontenjanın ilk ismi olarak, bizzat İsmet Pasa tarafından Atatürk'ü cok iyi anlayan kimse olduğu Parti Meclisi'nde duyurularak Kurucu Meclis'e seçildiğini kendisi parti kontenjanından seçilen, 1961'den sonra da Ordu Senatörü olan Zeki Kumrulu'dan öğrenmişti. Enver Ziya Karal'ın özel notlarından, s.109-111.

${ }^{104}$ Enver Ziya Karal'ın özel notlarından, s. 122 Sevket Süreyya Aydemir, Ikinci Adam (cilt III, s. 522) kitabında Anayasa Komisyonu Başkanı için"Kurucu Meclis derhal bir Anayasa Komisyonu seçmiş ve başına bir tarih bilgini olan Prof. Enver Ziya Karal'ı getirtmişti. Hislerine hakim, sakin mizaçlı, fakat bilgili ve realist bir inan olan Karal'ın bilhassa yakın tarihimizin gelişmeleri ve problemleri üstüne derine inen bir vukfu vardı. Seçildiği vazifede milli şartlarımızı ve icapları teraziye koyarak, çalışmaları başarılı istikamette yürüttü. Kamil Karavelioğlu da üç kez hukukçulardan oluşan heyetlerin başaramadı̆̆ 1 hukuk belgesini Kurucu Meclis Komisyonunun Karal'ın bilge ve istikrarlı başkanlığı altında hiçbir sorun çıkmadan, herhangi bir anlaşmazlığa düşülmeden hazırlandığını söylemektedir 
hazırlamak üzere dört ayrı alt komisyon kuruldu. ${ }^{106}$ Anayasanın sistematiğini ve yazılışına egemen esasları saptamak üzere kurulan Redaksiyon Komitesi de Celal Sait Siren, Cafer Tüzel ve Hıfzı Veldet Velidedeoğlu'ndan oluşmuştu. Bu komite, hazırlanan metinleri yasanın a. ana çatısı yani sistematiği, b. içeriğin yeni sözcükler uydurulmadan, genç kuşakların zorlanmadan kavrayabileceği "temiz ve duru bir Türkçe" ile anlatımını sağlamak üzere dilini ve c. her maddesinin gereken yerlere yan başlıklar koyularak incelenmesini kolaylaştıracak ${ }^{107}$ şekilde bir araya getirilmesini sağladı.

Anayasa taslağı Mart ayı başında tamamlanmış şekliyle Temsilciler Meclisi Başkanlığına sunulana kadar Anayasa Komisyonu Başkanı Ord. Prof. Dr. Enver Ziya Karal, Başkanlığı 5 raporla çalışmalar hakkında bilgilendirdi. ${ }^{108}$ Anayasa üzerinde çalışmalar sürerken zaman zaman Kurucu Meclis üyeleriyle bir araya gelinen özel toplantılarda çok yararlı görüş alışverişleri yapıldı. Madanoğlu başta, Milli Birlik Komitesi’nin bazı üyeleri de zaman zaman Anayasa Komisyonu Başkanı ve üyelerini davet ederek gelişmeler hakkında bilgi alırken örneğin, Genel Kurmay Başkanlığının Milli Savunma Bakanlığı'na bağlı olup olmaması gibi noktalarda yönlendirici de olmak istediler. Milli Savunma Bakanlığına bağlı Genel Kurmay Başkanlığının, Silahlı Kuvvetleri iktidarın elinde, onun siyaseti doğrultusunda yönlendirilmeye açık duruma getireceği, Demokrat Parti döneminde örneği yaşanmış ciddi bir kaygıydı. Nitekim, 27 Mayıs öncesinin Genel Kurmay Başkanı Rüştü Erdelhun, olaylar sırasında silahlı kuvvetleri Hükümetin isteği doğrultusunda yönlendirmiş, bu yüzden asker ayaklanmış, bu yüzden Erdelhun Yassıada'da yargılanmıştı. Yeni Anayasada Kurumun Başbakanlığa bağlandığı açıklanmış, benzeri tereddütler de zamanında giderilmişti

Anayasanın tamamlanmış olarak imzalanacağ 9 Mart sabahı Devlet Başkanı, 10.30'da Komisyon Başkanı ve sözcüleri kabul edip son bilgileri aldıktan sonra, aynı gün öğleden sonra 15:00'de Anayasa Komisyonu, raporu ile birlikte yasa tasarısını Temsilciler Meclisi Başkanlığına sunmak üzere Meclis Başkanı Kazım Orbay'ı konuk etti. Kısa bir törenle Başkan ve üyelerin her birinin imzaladığ 1 Anayasa, imza karşılığında Orbay'a Temsilciler Meclisi'nde görüşmeye açılmak üzere teslim edildi. Temsilciler Meclisi, 157 Sayılı Kurucu Meclis Yasasında belirlendiği üzere Meclisi

${ }^{106}$ Soysal, Mümtaz, Anayasaya Giriş, s. 154., Bu komisyonların çalışmaları ve her birinin hazırladığı maddeler ve sunuş raporları için bk. Kazım Öztürk, a.g.e. s. 449-555

107 Komisyonun Anayasa yaz1lırken izleyeceği yöntem 19 Ocak tarihli raporla açıklanırken metni herkesin anlayabilmesi için Türkçe sözcüklerin kullanılacağı, doğru sözler kullanılması açısından gerektiğinde Türk Dil Kurumu'na başvurulacağı belirtilirken Başkanının Türk Dil Kurumu üyesi olmasının Kurumla iletişimi kolaylaştıracağının altı da çizilmisti. Bk. Öztürk, s. 593

${ }_{108}$ Öztürk, Kazım, a.g.e., s.441-448. 
haftada en az dört gün anayasayı görüşüp tartışacak (Madde 30), Milli Birlik Komitesi Temsilciler Meclisi Genel Kurulundaki tartışma süresinin yarısında - 7 günden az olmamak kaydıyla-görüşmeleri tamamladıktan sonra Anayasa Kurucu Meclis bileşik toplantısında halk oyuna sunulacak hale getirilecekti (Madde 31). Bu çerçevede, Anayasanın referanduma hazır hale getirilmesi, inceleme ve düzeltmelerle yaklaşık beş ay aldı: ${ }^{109}$

Başlangıç, son üçü Son Hükümler başlığı altında 157 madde ve 11 geçici maddeden ${ }^{110}$ oluşan yeni Anayasa, her maddesi tartışılmış ve gerekli düzeltmeler yapılmış olarak 27 Mayıs'ta son şekliyle tamamlandı. 29 Mayıs Cumartesi günü Kurucu Meclis'te onandı. Meclisteki Anayasa oylamasında Temsilciler Meclisi'nde kullanılan 262 oyun 238'i ve Cemal Madanoğlu oylamaya katılmadığından M.B.K.'nin 22 yani toplam 260 olumlu oyla kabul edildi. 21 Haziran günkü toplantıda Kurucu Meclis, Anayasayı halka anlatma ve ulusu aydınlatmak için on gün boyuca her ile üç Temsilciler Meclisi üyesinin gitmesini kararlaştırdı. ${ }^{111}$

\section{Anayasanın Bazı Özellikleri}

Bir askeri ihtilalden sonra hazırlanan 1961 Anayasası, buna yol açan etkenlere meydan vermeyecek donanımda olması önde tutularak hazırlanmış, demokratik yönetimin en öncelikli gerekleri arasında yer alan yasama, yürütme ve yargının birbirinden ayrılığı ilkesi üzerine geliştirilmişti. İhtilalin yapılmasının hukuksal dayanağı anayasanın çiğnenmesi olduğundan, Anayasa'da bireysel ve kamusal güvence olarak yarg1 bağımsızlığına güçlü yargı sistemine özel önem verilmişti. Anayasa Komisyonu Başkanı Karal, Temsilciler Meclisi incelemesine sunulan Anayasa'nın niteliklerini özetlerken ilkinin a. 27 Mayıs İnkılabının getirmiş olduğu bir devrim ve zihniyet mahsulü olduğundan, b. Atatürk inkılaplarını ele alarak onlara gerçek değerlerini verdiği, c. İnkılapçılık ruhuna uygun yeni müesseseler getirdiği ve d. Ulusun ileriye atılma temayül ve istidadına yolu açan kuralları getirdiği için inkılapçıllı̆̆ şeklinde açklamıştı. İkinci özelliği olarak doktrinci olmadığının, üçüncü olarak demokrasi ve hukuk devleti esaslarını benimsediğinin ve son olarak da ulusun refah ve saadetine önem vermekle birlikte bu konularda belli bir felsefeye sahip olduğu

${ }^{109}$ Temsilciler Meclisi 30 Mart günü görüşmeye başladığ 1 tasarıyı 26 bileşimde, 81 oturumda 188 saat ve 55 dakikalık tartışmalardan sonra onaylamıștı. Milli Birlik Komitesi her çalışmayı tutanağa geçirmemişse de kayıtlı olan 7 bileşim ve 13 oturumda 32 saat 30 dakika, Kurucu Meclis de 2 bileşim ve 2 oturumda 3 saat 32 dakikada Anayasayı onamıştı. Toplam olarak 224 saat 57 dakikalık çalışma (bk. Öztürk, a.g.e., s. XXII) sonunda, Kurucu Mecliste açık oyla oylanan tasarı ancak bu yoğun denetleme süzgeçinden sonra halk oyuna sunulmuştu. Kazım Öztürk'ün 93. dipnotta değindiğimiz yapıtı bu aşamaların her birindeki tartışmaları içermektedir.

${ }_{110}$ Geçiçi maddeler, 4. Madde Milli Birlik Komitesi Kurucu Meclis ve Temsilciler Meclisi'nin son bulduğunu içerenle birlikte, yeni Anayasanın geçerlik kazanmasından sonra ilk uygulamaları tarihleriyle içeren maddelerdir.

${ }_{111}^{1}$ T.C. Kurucu Meclisi Tutanak Dergisi, Cilt 1, 27, 21.6.1961, s. 109-130. 
belirtisini taşımadığı ve insanlık ülkülerine uyumlu olduğunun altını çizmişti. ${ }^{112}$

$\mathrm{Bu}$ nitelikleri çerçevesinde Anayasanın en büyük özelliği, sayısal üstünlüğe sahip olan iktidar partisinin bu üstünlüğün verdiği güvenle yargıya, basına, üniversiteye hatta güvenlik güçlerine baskılarla ulusu sindirmesini ve T.B.M.M.ni çalışamaz noktaya getirmesini önleyecek yeni getirimleriydi. Kurumlaştırılan bu yeniliklerin başında yasama organını ikili meclis yapan ${ }^{113}$ Senato ile bir denet ve güvence organı olarak yarg1 bağımsızlığını koruyan Anayasa Mahkemesi geliyordu. Bunların yanı sıra hakimlerin görevlerinde bağımsız olduğunu (132. Madde) ve azlolunamayacağını (görevine son verilemeyeceğini - 133. Madde) vurgulayarak yargı organını güçlendiren hakim teminatı, Yüksek Hakimler Kurulu, üniversite özerkliği, basın özgürlüğü, sendikalar, toplu sözleşme, grev hakkı gibi çağdaş olgular, eşitliğin, demokrasinin, insan haklarının güvencesi olarak Anayasada yer almıştı. Bu kurumlaşma, anayasanın Atatürk devrimlerine bağ $l_{1}$, insan hak ve hürriyetlerine saygıll, demokratik hukuk devleti için hazırlandığını vurgulayan Başlangıç kısmında da vardı. "Genel Esaslar" başlıklı ilk bölümde "Egemenlik kayıtsız şartsız Türk Milletinindir. Millet, egemenliğini Anayasanın koyduğu esaslara göre, yetkili organlar eliyle kullanır." denmekteydi. Yani, egemenlik, 1924 gibi T.B.M.M. eliyle kullanılmak üzere değil, "anayasanın koyduğu esaslara göre yetkili organlar eliyle kullanılmak üzere" ulusundu. Bu saptama, yukarıda vurgulandığ 1 gibi, oy çoğunluğuna dayanan Meclis'in ülkenin kaderine hakim olma güvenilirliğine yetmeyeceğini belirtip yargı organının önemini arttırıp Anayasa Mahkemesi'nin durumunu güçlendirerek yeni anayasayı egemenliği genel seçimle gelmemiş üyelerin de eline teslim etmekle farklı yapmaktaydı. ${ }^{114}$

1924 Anayasası'na Atatürk'ün Anayasası olarak bakıldı ğından, yeni tasarıdaki farklı yaklaşım, kimi çevrelerde Atatürk'ten kopma gibi algılanarak "sorun anayasada değil, onu uygulayan iktidarlardaydı" türünden sert eleştirilere yol açmıştı. Oysa yeni Anayasa, Cumhuriyeti, geçirilen deneyimlerden de alınan derslerle, daha güçlü temellere dayandırmak hedeflenerek hazırlanmıştı. Aslında yeni tasarıda gelinen bu nokta, 1961 Anayasası'nı çok ileri aşamaya taşıyan özellikti. Şöyle ki, İkinci Dünya Savaşı'ndan sonra anayasalarında düzenlemeler yapan bazı batı devletleri, bazı saptamalarla ulus egemenliğinin kayıtsız koşulsuz uygulanmasını sınırlandırmıştı. Bu saptamalar, her ülkenin iç dinamiklerine göre

${ }^{112}$ Öztürk, Kazım, a.g.e. s. 626.

${ }^{113}$ Enver Ziya Karal, bu sistemi Temsilciler Meclisi Senato ve ayrıca, ikisinin birleşiminin oluşturduğu bir Parlamento olduğu için, Üçlü Meclis sistemi olarak adlandırmaktadır.

${ }^{114}$ Soysal, Mümtaz, a.g.e. s. 160. 
oluşturulan kurumlar, bir de uluslar arası anlaşmaların anayasalara uygunluğu ve karşılıklılık ilkesi korunduğu sürece yasaların üstünde olacağına yönelik kararlardı. Kamuoyu lehine olan benzeri düzenlemelerin 1961 Anayasa metni içinde yer alması da Temsilciler Meclisi'nde onaylandıktan sonra kesinlik kazanmıştı. Bu çerçevedeki sınırlamalar, yakın geçmişte yaşanmış olan oy çokluğuna sahip yönetimin baskısının süregelen korkusu ile hazırlanmış, bu nedenle de toplumu Meclis aritmetiğinde bu çoğunluğa sahip siyasal partinin tutsağı olmasını önleyecek kurumlar getirilmişti. Nitekim, dünya demokrasilerinde de görülen bu kaygı doğrultusunda yıllar içinde uluslar arası bağıtlar gündeme gelmişti. Kaldı ki zaman, bu kaygıyı haklı kıldı. Özellikle günümüzde, yıllarca koalisyon yönetimlerinden sonra 2002 yılından partisi tartışmasız oy çoğunluğuna sahip iktidar partisinin Meclisi, hükümeti ve sadece anayasayı değil, laik T.C. devletini tehdit eden uygulamalara sarılamıyorsa bu hala geçerli olan 1961 Anayasası kurumları ve bu kurumlar eliyle Türkiye'nin de dahil olduğu uluslararası bağıtlar, örneğin, İnsan Hakları Mahkemesi sayesinde olduğunu burada hatırlatmadan geçmemeliyiz.

Anayasanın özellikleri belirtilirken üzerinde durmak gereken bir başka önemli nokta da metnin içeriğinde Atatürk ilke ve devrimlerinin vurgulandığı maddelerdir. Anayasanın bir parçası olarak kabul edilen Başlangıç kısmında “Atatürk Devrimlerine bağlılığın”, içeriğindeki değişik maddelerde de dolaylı olarak ilkelerinin her birine ayrı yer almasının, "Çeşitli Hükümler" Kısmındaki 153. madde ile ${ }^{115}$ 1924-1934 yılları arasında çıkarılan laiklikle ilgili yasaların sıralanarak bunların birinin anayasal güvenceyle koruma altına alınmasının iki önemli açıklaması vardır. Bunların ilki, Atatürk ilkelerinin ve Türk devriminin getirilerinin Türkiye'nin laik, demokratik, çağdaş, bütüncül bir hukuk devleti olarak geleceğinin tek

${ }^{115}$ Madde 153 - "Bu Anayasanın hiçbir hükmü, Türk toplumunun çağdaş uygarlık seviyesine erişmesi ve Türkiye Cumhuriyetinin laiklik niteliğini koruma amaçnı güden aşağıda gösterilen Devrim kanunlarının, bu Anayasanın halkoyu ile kabul edildiği tarihte yürürlükte bulunan hükümlerinin Anayasaya aykırı olduğu şeklinde anlaşılamaz ve yorumlanamaz:

1. 3 Mart 1340 tarihli ve 450 sayılı Tevhid-i Tedrisat Kanunu

2. 25 Teşrinisani 1341 tarihli ve 671 sayılı Şapka İktisası hakkında Kanun

3. 30 Teşrinisani 1341 tarihli ve 677 sayılı Tekke ve Zaviyelerle Türbelerin Seddine ve Türbedarlıklar ile Bir Takım Unvanların Men ve İlgasına Dair Kanun

4. 17 Şubat 1926 tarihli ve 743 sayılı Türk Kanunu Medeniyesiyle kabul edilen evlenme akdinin evlendirme memuru tarafından yapılacağına dair medeni nikah esası ile aynı Kanunun 110ncu maddesi hükmü;

5. 20 Mayıs 1928 tarihli ve 1288 sayılı Beynelmilel Erkanın Kabulü hakkında Kanun

6. 1 Teşrinisani 1928 tarihli ve 1353 sayllı Türk Harflerinin Kabulü ve Tatbiki hakkında Kanun

7. 26 Teşrinisani 1934 tarihli ve 2590 sayılı Efendi, Bey, Paşa gibi Lakap ve Unvanların Kaldırıldığına dair kanun. Kanun.

8. 3 Kanunuevvel 1934 tarihli ve 2596 sayılı Bazı Kisvelerin Giyilemiyeceğine dair 
güvencesi olmasıdır. Cumhuriyet tarihi, bu özden sapmaların ülkeyi bunalımlara sürüklediğini gösteren örneklerle doludur. Zaten Anayasa'nın hazırlanmasına yol açan Demokrat Parti döneminin yasatanımaz uygulamalarının temelindeki neden, iktidarın meclis çoğunluğunu elde tutabilmek için oy kaygısıyla özellikle laiklikten verilen anayasa çiğneme boyutundaki ödünler olduğu, hatta bu iktidarın başa gelmesiyle bir karşıdevrim başlatıldığı pek çok yapıtta da yer almaktadır.

İkinci neden de Atatürk ilkelerinin - ve elbette Türk Devrimi'nin Anayasanın yapıldığı tarihe kadar henüz yeterince özümsenmemiş olmasıdır. Her devrim ilkelerini öğrenerek özümsemiş kuşaklar yetiştirerek geleceğe uzanabileceğinden, bunu sağlayacak bir eğitim sistemi getirip ona sarılırken Türk Devrimi ile gelen ulusal, laik eğitim sistemi, kısa bir dönemden sonra uygulanamadığından, Türkiye'de Osmanlı'da olduğu gibi, tekrar iki farklı dünya görüşüne sahip kuşaklar yetişmeye başlamıştır. Ulus ülküsü ümmete dönüşmüş, bilime, sorgulamaya uzak; öbür dünyaya endeksli, itaatkar kuşakların yetişmesi, yine ülkenin ekonomik sıkıntılarını örtbas edebilmek için iktidara yapışmak isteyen siyasilerin üstelik yurt dişından da destek alarak sarıldığı silah olmuştur. Ne yazık ki Türk Devrimi'nden bu yana neredeyse yarım asır geçmiş olmasına karşın bu konularda Türk toplumunun aynı yerde olduğunu, hatta daha da geriye gittiğini, tekrar benzeri siyasal anlayışların iktidara sarılmasıyla tırmanan türlü bölücülüklerle cumhuriyet ve demokrasi gibi ulusal bütünlüğün de tehlikeye düştüğünü söylemek durumundayiz.

\section{Anayasa Hazırlanırken Tartışılan Bazı Noktalar}

Daha önceki sayfalarda, ilk Anayasa tasarısının maddeleri hazırlanırken bu maddeleri hazırlayanlar arasında çalışmaları sonuçsuz kılan anlaşmazlıklar ve tartışmalar olduğundan söz etmiştik. Kuşkusuz bu tartışmalar, bazı konuların önceden terk edilmesini, bazılarında da bir takım düzenlemelerle gündeme getirilmesine önayak olmakla son metnin daha uyumlu bir atmosferde hazırlanabilmesine yardımcı olmuştu. Bununla birlikte, son şeklini vermek üzere Anayasa maddeleri üzerinde Komitede ve Temsilciler Meclisinde yapılan görüşmeler sırasında maddelerde bazı değişikliklerin yapılmasıyla sonuçlanan tartışmalar oldu. ${ }^{116}$.

Anayasa'nın çok önemli bir getirisi olan ve Türk hukuk yaşamına ilk kez tanıtılan Anayasa Mahkemesi, yeni döneminde Türkiye Cumhuriyeti'nin yasaların göz ardı edilemediği, demokratik, çağdaş bir hukuk devleti olabilmesinin güvencesiydi. Bu özelliği kavranmış olduğundan bu kurum Temsilciler Meclisi'nde çok ayrıntılı olarak tartışılan konulara örnektir. Üyelerin çoğu, çok geniş, hatta en üst yetkilere sahip bu mahkemenin

${ }^{116}$ Kazım Öztürk'ün değinilen yapıtının II. ve III ciltlerinde tutanaklardaki bütün tartışmalar vardır. 
üyelerinin siyasal ve düşünsel kimliklerinin uygulamalarına yansıyacağı kaygısıyla, tamamen tarafsız olan ve Meclis tarafından seçilmeyen üyelerden oluşmasını istiyordu. Meclis aritmetiğinin ulusal çıkarları kişisel çıkarlar haline dönüş̧ürmesi kaygısıyla dile getirilen bu istek, Anayasa Mahkemesi'nin 15 asli üyesinin üçünün Meclis tarafından seçilmesi öngörülmüşken, Meclisin üye seçme hakkı olmaması yönünde uzun tartışmalardan sonra bu sayı üçe indirilerek maddeleşti. ${ }^{117}$

Geçmiş dönemin yarattığı kaygıların izlerini taşıyarak Temsilciler Meclisinde çok tartışılan konulara bir örnek de Genel Kurmay Başkanlığı'nın Milli Savunma Bakanlığı ile doğrudan bağlantılı olup olmamasıydı. Silahlı Kuvvetlerin politikanın dişında, hatta üstünde olması kimi üyelere göre ülke güvenliği için vazgeçilmez bir zorunluluktu. Kimileri de bu uygulamanın demokrasiyle bağdaşmayacağını öne sürmekteydi. Daha önce Devlet Başkanın bile dile getirdiği kuşkular yaratarak tartışılan bu konu sonunda Silahlı Kuvvetlerin Komutanı olan Genel Kurmay Başkanı'nın atanma şeklinin de tanımlandığı 110. Madde'de 'yasayla düzenlenen görev ve yetkileriyle Başbakanlığa sorumlu olduğu' ş̧ekliyle yer aldı.

Cumhuriyet tarihinde ilk kez İkili Meclis sistemi uygulanacağından, üstelik bir de Milli Birlik Komitesi üyelerinin Tabii Senatör yapılmaları gündeme geldiğinden, Anayasayı hazırlayanlar arasında da uzayan görüşmelere yol açmış olan bu konu da, Temsilciler Meclisinde de zaman zaman sertleşen tartışmalara yol açtı. Komisyonda "Cumhuriyet Meclisi"

1171961 Anayasa'nın günümüze de taşınan özelliği ve bugün laik Türkiye Cumhuriyeti'nin çok güçlü bir teminatı olan Ảnayasa Mahkemesi’nin bu araştırmanın yapıldığı, tekrar değiş̧ime uğramasının konu edildiği günlerdeki çok önemli durumunu dikkate alarak 1961 Anayasası'nda üyelerinin seçimi ile ilgili maddeyi aynen veriyoruz:

"Madde 145 - Anayasa Mahkemesi onbeş asıl ve beş yedek üyeden kuruludur. Asıl üyelerden dördü Yargıtay, üçü Danıştay Genel Kurullarınca, kendi Başkan ve üyeleriyle Başsavcı ve Başkanunsözcüsü arasından üye tamsayıların salt çoğunluğu ile ve gizli oyla seçilir. Bir üye, Sayıştay Genel Kurulunca kendi Başkan ve üyeleri arasından aynı usulle seçilir. Millet Meclisi üç, Cumhuriyet Senatosu iki üye seçer. Cumhurbaşkanınca da iki üye seçilir. Cumhurbaşkanı, bu üyelerden birini, Askeri Yargıtay genel kurulunun üye tamsayısının salt çoğunluğuyla ve gizli oyla göstereceği üç aday arasından seçer. Anayasa Mahkemesi, kendi üyeleri arasından, gizli oyla ve üçte iki çoğunlukla, dört yıl için bir Başkan ve Başkanvekili seçer; yeniden seçilmek caizdir.

Yasama Meclisleri, bu seçimleri, Türkiye Büyük Millet Meclisi üyeleri dışından, üye tamsayılarının üçte iki çoğunluğu ile ve gizli oyla yaparlar. İlk iki oylamada bu çoğunluk sağlanamazsa, salt çoğunlukla yetinilir. YASAMA Meclislerince seçilecek üyelerden birer kişinin, üniversitelerin hukuk, iktisat ve siyasal bilgiler öğretim üyelerinin birlikte toplanarak, açık üyeliklerin üç katı tutarında ve gizli oyla gösterecekleri adaylar arasından olması gereklidir.

Anayasa Mahkemesine asıl veya yedek üye olabilmek için 40 yaşını doldurmuş bulunmak ve Yargıtay, Danıştay, Askeri Yargıtay veya Sayıştay’da başkanlık, üyelik veya Başsavcılık, Başkanunsözcülüğü veya üniversitelerde hukuk, ,iktisat ve siyasal bilimler alanlarında en az beş yıl öğretim üyeliğ́i veya onbeş yıl avukatlık yapmış olmak şarttır.

Anayasa Mahkemesine Yargıtay 2, Danıştay ile Yasama Meclislerinin her biri birer yedek üye seçerler. Yedek üyelerin seçiminde de, asılların seçimindeki usul uygulanır.

Anayasa Mahkemesi üyeleri, resmi veya özel hiçbir görev alamazlar.” , 
adıyla benimsenen, tasarıda da "İkinci Meclis" olarak sözü edilen bu meclisin, öncelikle amacının Birinci ile aynı güçte bir Meclis çıkarmak değil, yasaların gerekçelendirilmesine ve kamu oyu tarafından daha iyi anlaşılmasına da yardımcı olacak ve denetleyecek bir kurum oluşturmak olduğunun anlatılması gerekiyordu. Ancak Komisyonun görüşü, bazı noktalarının da Seçim Yasası ile belirlenmesiydi. Nitekim, Milli Birlik Komitesi üyelerinin Tabii Senatör yapılmaları yanı sıra, Senatonun 40 kişilik tarafsız bir heyetten oluşmasının Anayasa maddesi yapılması Kurucu Meclis'teki Milli Birlikçilerden Ahmet Yıldız tarafından özel bir söyleşide Anayasa Komisyonu Başkanı'na önerildiğinde, Karal, bu öneriye halkın anayasayla sadece tarafsız aday seçmek zorunda bırakılmasının milli iradeye uygun düşmeyeceği, ayrıca, o koşulda seçilenlerin daha sonra bir siyasi partiye girmesini önlenemeyeceği, bunların seçim yasası ile sağlanması gerektiğini vurgulayarak karşı çıkmıştı. ${ }^{18}$ Sonunda, İkinci Meclis'in yasal konumunun hem Anayasa hem de Seçim Yasası ile belirlenmesinde anlaşma sağlandı. Bu bağlamda metinde İkinci Meclis'in gerekçelendirilmesi, Yasama organının bir parçası olarak "Birinci Meclis'te beliren siyasi tercihleri, temelinden değiştirmemek şartıyla yeniden gözden geçirecek; kendi seçim tarihlerinin ve bu sebeple üyeleri arasındaki siyasi guruplaşma nisbetlerinin Birinci Meclisten az-çok farklı oluşu dolayısıyla, oradaki siyasi tercihlerin kamu oyundaki çoğunluğu daha yakından takip edebilmesini sağlayacak: tartışmalarda derinlik ve geniş̧lik yaratacak: Birinci Meclis'teki tercihin etraflı tartışmalar yoluyla, halk oyuna daha iyi aksetmesini kolaylaştıracak ve nihayet Birinci Meclis’teki tartışma usullerinin ve sürat zaruretlerinin yaratabileceği mahsurları önleyecektir"119 şeklindeydi. Cumhuriyet Senatosu adı, genel görüşmeler sırasında isim etrafında türlü tartışmalardan sonra kesinlik kazandı ve Anayasa'da "Türkiye Büyük Millet Meclisi, Millet Meclisi ve Cumhuriyet Senatosundan kuruludur" maddesiyle (Madde 63) yer aldı. Yetkileri de "Kanun koymak, değiștirmek ve kaldırmak, Devletin bütçe ve kesin hesap kanun tasarılarını görüssmek ve kabul etmek, para bastırılmasına, genel ve özel af ilanına, mahkemelerce verilip kesinleşen ölüm cezalarının yerine getirilmesine karar vermek, Türkiye Büyük Millet Meclisi'nin yetkilerindendir" içerikli 64. madde ile tanımlanmıştı. ${ }^{120}$

\footnotetext{
${ }^{118}$ Enver Ziya Karal'ın özel notları, s. 167.

${ }^{119}$ Öztürk, Kazım, a.g.e., s. 490-491.

${ }^{120}$ Cumhuriyet Senatosunun üyeleri, nitelikleri, seçimleri Anayasanın 70-73 maddeleriyle tanımlanmıstı. Bu cerçevede Senatonun genel oyla secilen 150 ve Cumhurbaşkanı tarafından seçilen 15 üyeden ( y.n:Bu gruba Kontenjan Senatörü adı verildi) kurulduğu, 13 Aralık 1960 tarih 157 sayılı yasayla Milli Birlik Komitesi üyeleri ve eski Cumhurbaşkanları, yaş kaydı gözetilmeksizin, ancak, siyasal partiye girmemek kaydıyla Cumhuriyet Senatosunun tabii üyesi sayılıyorlardı. Kırk yaşını doldurmuş ve yükssek öğrenim görmüs olmak, senatör adaylığı için milletvekilinde aranan koşullara ek olarak öngörülürken üçte biri iki yılda bir yenilenen altı yıllık dönem için seçilmelerinde milletvekili seçimlerindeki gibi seçmen yaşına ulaşmış her Türk vatandaşı oy sahibiydi. İlginçtir ki
} 
Temsilciler Meclisi'ndeki tartışmalar sırasında çok üzerinde durulan bir konu da oy hakkının bilinçli kullanılması için Anayasada öğrenim düzeyi ile sınırlanmasıydı. Bunun hiç olmazsa Senato üyelerinin seçiminde uygulanması çok tartışıldı ve sonunda, anayasal madde olan seçme seçilme hakkının koşullarının belirlenmesi gibi çok önemli de olsa bazı konuların Anayasa'yla değil, ona uygun olarak hazırlanacak yasalarla saptanması benimsendi.

Anayasa maddeleri son şekline getirilirken sadece birkaç örnekle yetinmek zorunda kaldığımız tartışmalar, aslında tasarının çok sesli parlamenter demokrasiyi getiren özelliği ile doğrudan ilgili olarak Temsilciler Meclisi'nin incelemesine sunulmasının doğal getirileri, demokrasinin de gereğiydi.

\section{Anayasa İçin Halk Oylaması (Referandum)}

Anayasanın halk oyuna sunulması ve "evet" oyu alırsa yürürlüğe koyulması, Kurucu Meclisin kurulmasıyla birlikte alınmış bir karardı. Bu işlem için Mart ayı sonunda bir de on maddelik yasa çıkarılmıştı. ${ }^{121}$

İhtilalin ilk günü yeni bir Anayasa hazırlanacağı duyurulmuştu; geçen bir yıl boyunca ilgili gelişmelerle basın ve radyoda sürekli gündemde kaldığından, kamuoyu bu konuya hiç de uzak değildi. Bununla birlikte, Anayasa için ilk kez halk oyuna başvurulacağından, özellikle kamulaştırma, devletleştirme, toprak mülkiyetine ilişkin maddeleriyle halkı yepyeni bakış açılarıyla donatacak, topluma sosyal alanda olduğu kadar ekonomik alanda da yepyeni ufuklar açacak olan yasanın kamuya sunulan son şeklinin iyi anlaşılması için güncel Türkçe ile yazılmasına büyük özen gösterilmiş, içeriğinin sorular giderecek şekilde açıklanmasına bir zorunluluk olarak bakılmıştı. Kaldı ki Türk vatandaşların bu yasanın sağladığı çok geniş haklardan bilinçli bir şekilde yararlanabilmesi, getirileni çok iyi kavramış olarak Anayasanın uygulanışını denetlemesi ile olasıydı. Bunun için konuya neredeyse bir seferberlik başlatılırcasına yaklaşıldı ülkenin her köşesine Temsilciler Meclisi üyelerinin Anayasanın içeriğini halka anlatacağı tanıtma gezileri düzenlenmesi kararlaştırıldı.

Yukarıdaki yasa çerçevesinde yapılacak halk oylaması açısından üç noktaya büyük önem veriliyordu. Bunların ilki, yukarıda da açıklandığı gibi, Anayasanın iyi anlaşılmasıydı. Türk toplumunun 1876 yılında anayasal

Demokrat Parti iktidarına son veren 27 Mayıs ihtilalinin getirisi olan Anayasanın bu maddeleri, bir süre sonra, ölüm cezasına çarptırılan, ancak ileri yaşı dolayısıyla cezası ömür boyu hapse çevrilen Demokrat Parti döneminin Cumhurbaşkanı Celal Bayar'1 tutuklu D.P.'lilere af çıtıktan sonra, ölümüne kadar yıllarca Milli Birlikçilerle Senatör olarak yan yana oturacağı Türkiye Büyük Millet Meclisi'ne getirecekti.

${ }^{121}$ T.C. Kurucu Meclisi Tutanak Dergisi, Cilt 1; Anayasanın Halkoyuna Sunulması Hakkında Kanun Kanun No. 283, Kabul tarihi 28.3.1961,Resmi Gazete ile İlanı:1.4.1961Sayı:10771. 
yönetimle tanıştığı, II. Abdülhamit döneminde 30 yıl gibi önemli bir zaman dilimi içinde askıya alınmış olsa da 1908 'den beri bu uygulamanın sürdürüldüğü anımsanınca, seksen yılı aşan bir sürede anayasal geleneğin oturmuş olduğu öne sürülebilir. Ancak, anayasal sistemin uygulayan ve uygulanan olarak toplumsal bilinçlenme ve sorumlulukla bağlantılı olduğu dikkate alındığında bu yargının çevresinde soru işaretleri belirmektedir. Unutmamak gerekir ki Türkiye'de gerçek anlamda toplumsal bilinçlenmenin yolu, ancak Cumhuriyetin duyurulmasından sonra açılmıştı. Kaldı ki bilimsel, laik, ulusal eğitimin getirildiği 3 Mart 1924 tarihli Tevhid-i Tedrisat Kanunu (Öğrenim Birliği Yasası) ile açılan bu yolun Atatürk'ün ölümünden, hele 1948 'de laik özüyle çelişerek ilk öğretimde tekrar din derslerine yer verilmesinden sonra ne kadar uygulanabildiği gitgide daha çok tartışılır hale gelmişti. ${ }^{122}$

İkincisi, referanduma katılımın yüksek olmasıydı. Cumhuriyet tarihinde ilk kez referandumla karşılaşan Türk halkının sandık başına giderek oy kullanması gerekiyordu. Her ne kadar yılında Hatay anavatana katılırken halkın onayı aranmışsa da o zamanki uygulama, yöre halkının oyuna başvurulan plebisit olarak kalmıştı. Anayasa içinse genel seçimlerdeki gibi oy kullanma yaşındaki bütün Türk vatandaşlarının oy kullanması isteniyordu. Verilen oylar, Ulusun egemenliğine dayalı bir yönetim biçiminde toplumun bu yönetimin özünü oluşturacak kuralları onaylamasını, onlara uymasını, hatta siyasetçilerden de bu uyuma özen göstermelerini istemesini sağlayacaktı. Bütün 'sandık başına gitmeler' gibi, bu da toplumsal bilinçlenme ve sorumlulukla bağlantılıydı.

Üçüncü nokta da yüksek sayıda "evet" oyu sağlanabilmesiydi. Olumlu oyların oranının yüksekliği Anayasa'nın yaşam güvencesi olacaktı. Türk toplumuna sosyal devlet anlayışını, kişisel hak ve özgürlükler yönünden ileri ülkelerde sağlanan en ileri donanımı, bunları sağlayacak kurumları ve

${ }^{122}$ Değişik kademeleriyle eğitim-öğretim, kendine özgü yasayla belirlenmesine karşın laik bir ülke ve laik bir toplumun can damarı olan laik eğitim zaman içinde bu yasada türlü değişikliklerle delinmiş, en sonunda da 12 Eylül Anayasası içine yerleştirilen maddelerle, özellikle de bu anayasadan güç alan kuran kursları ve özel cemaat, tarikat okullarıyla eylemsel olarak son bulmuştur. Eğitim, 1961 Anayasası'nda Kişinin Hak ve Görevleri kısmında şöyle yer almıştı: " 22 Madde - Herkes bilim ve sanatı serbestçe öğrenme ve öğretme, açıklama, yayma ve bu alanlarda her türlü araştırma yapma özgürlüğüne sahiptir. Eğitim ve öğretim, Devletin gözetim ve denetimi altında serbesttir. Özel okulların bağlı olduğu esaslar, Devlet okulları ile erişilmek istenen seviyeye uygun olarak kanunla düzenlenir. Çă̆das bilim ve eğitim esaslarına aykırı eğitim ve öğretim yerleri açılamaz." Sosyal ve İktisadi Haklar ve Ödevler kısmının 50. Maddesi de şöyledir. "Halkın öğrenim ve eğitim ihtiyacını sağlama Devletin başta gelen ödevlerindendir. İlköğrenim, kız ve erkek bütün vatandaşlar için mecburidir ve devlet okullarında parasızdır. Devlet, maddi imkanlardan yoksun, başarılı öğrencilerin en yüksek öğrenim derecelerine kadar çıkmalarını sağlama amacıyla burslar ve başka yollarla gerekli yardımı yapar. Devlet, durumları sebebiyle özel eğitime ihtiyacı olanları, topluma yararlı kılacak tedbirleri alır. Devlet, tarih ve kültür değerleri olan eser ve anıtların korunmasını sağlar". 
hepsinin yaptırımı yönünden de en geniş güvenceyi veren Anayasa'nın Türk toplumunun "devlet babanın" öngördü̆ğünü sorgusuz kabul etme alışkanlığını değiştirerek kendi çıkarlarına sahip çıkıp koruma alışkanlığını getirmesi de bekleniyordu. Türkiye'nin sosyo kültürel yapısı nedeniyle oy kullanan herkesin genel seçimlerde bile etki ve baskı altında kalmadan özgür iradeleriyle kendi kararları doğrultusunda hareket ettikleri öne sürülemediğinden, oylamadan önce ciddi bir tanıtımla insanlara anayasanın ve sağlayacağ $\breve{1}$ hakların iyi anlatılması çok önemliydi. Eşitlik, demokrasi, halkın eğitim kültür düzeyinin düşük, ekonomik koşullarının kötü olduğu kesimlerde sadece kağıt üzerindeydi. Geleneklere tutsaklıkla ekonomik özgürlüğe sahip olsalar bile kadınlar kocalarının, evlatlar babalarının sözü dışına çıkamazken, Toprak Ağası da Anadolu'nun yadsınamayan bir gerçeğiydi. Anayasada, bu çağ dışı uygulamaların aşılması hedeflenmişti.

Öbür iki nokta gibi bu da Anayasa'nın özenle hazırlanan içeriğinin iyi anlaşılmasını gerektiriyordu ki bu da üst düzeyde olduğu öne sürülemeyen toplumsal bilinçlenmeyle doğrudan ilişkiliydi. Bu nedenle, görevli Temsilciler Meclisi üyelerinin yanı sıra, askeri yönetim uzadıkça büyüyen demokrasiye bir an önce dönülmesi isteğiyle, pek çok aydın, gönüllü tanıtıcı oldu. Bir çok kurum da kendiliğinden tanıtım ekibi gibi çalıştı.

Anayasa propagandası yürütmek üzere kendilerine ayrılan bölgelere giden Temsilciler Meclisi üyeleri yoğun programlarını aksatmadan ilçelere, hatta köylere kadar uzanıp halkla görüsştüler. Sevindirici bir şekilde çoğu yerde hatırı sayılır sayıda kadın dinleyicilerin de bulunduğu meydanlardaki söylevleri izleyenlerin, kahvehane, okul veya ev sohbetlerinde görüştükleri kimselerin sorularını yanıtladılar. Geziler ve konuşmalar sırasında propaganda ekiplerinin sık sık karşılaştıkları bir sorun, Demokrat Parti yandaşlarının aynı yoğunluktaki kampanyayla Anayasayı halka Milli Birlikçilerin, hatta Halk Partisinin anayasası olarak tanıtmalarıydı. Söz verildiği gibi Anayasa ve seçimin hemen gerçekleşmemesi, Eminsular, 147'ler, 14'ler gibi olaylar yaşanıp Komitenin iç çekişmeleri dışarıya yansıması, siyaset dışında kalacaklarına söz veren Komite üyelerine Tabii Senatör olarak Anayasayla siyasal yer sağlaması, Yassıada duruşmalarının 27 Mayıs'tan ancak yaklaşık beş ay sonra başlayıp uzaması, bu kampanyaya hem neden hem de katkı oldu. Referandum gezilerinde karşı propagandacıların saydığımız etkenlerle kitleleri Anayasa aleyhine tutsak almaları, hiç de zor olmadı. Hele inanç öğesinin bilim ögesinin karşısındaki yerini koruduğu cahil halk kesimleri, kendilerine Kuranı Kerim'den örneklerle gösterilen hayır-şer (kötülük) dengesi karşısında "Elbette 'hayır' oyu kullanacağız. Kur'an bile onu emrediyor" söylemiyle "evet"çilere arkalarını dönüyorlardı. İnanılması zor bu kelime oyunu, yine inanılması zor oranda etkili olmaktaydı. Sözün özü, sıraladığımız tüm etkenlerin bir araya 
gelmesi, "evet" lerin galip geldiği referandumda Anayasa'nın nedereyse kıl payı ile kabul edilmesini getirdi:

Anayasa, 9 Temmuz günü halk oyuna sunuldu. Yüksek Seçim Kurulu'nun bildirdiği sonuçlara göre halkoylamasına 11,735,000 kayıttı seçmenden 10,282,561 kişi katılmış, 10,222,169 geçerli oyun 3,934,370'i olumsuz çıkmıştı. Kullanılan oyların yüzde 60.42 ü olan $6,368,191$ evet oyuyla ${ }^{123}$ Türkiye Cumhuriyeti'nin yeni Anayasas1, Kanun No 334 Kabul Tarihi 9/7/1961 olarak hemen yürürlüğe girdi. Anayasa ile eş zamanlı olarak Seçim Yasası da tamamlanıp yürürlüğe girdiğikten hemen 15 Ekim'de seçim yapılması için karar alındı. Anayasa ilk sınavını seçim sonuçlarına göre verecekti.

\section{Ekim Seçimleri ve Sonuç}

27 Mayıs'1 izleyen 1,5 yıl içinde gelinen aşamada Anayasa Komisyonu'nun ve Kurucu Meclis'in en önemli işlevi tamamlanmış gibi gözüküyordu. 4 Eylül'de Kurucu Meclis lağvedildi. Seçim sonuçlarına göre olası siyasal baskıları önlemek için Yassıada kararları vatandaşlar sandık başına gitmeden, 15 Eylül günü açıklandı. Yassıada kararlarındaki müebbet hapisler ve idam cezalarından üçünün üstelik oy birliği de sağlanmamasına karşın Milli Birlik Komitesinin onayından geçerek infazı, 27 Mayıs'a en büyük gölgeyi düşürdü, bazıları için de hiç dinmeyecek bir acı yaptı. 27 Mayıs, C.H.P. ve İnönü ile özdeşleştirildiğinden, demokratik yönetimin en olagan yansıması olan iktidar-muhalefet ikilemi bir kez daha neredeyse düşmanlık boyutuna taşındı. Dolayısıyla, D.P. yandaşları, Yassıada mağdurları, ilk günlerde çok kısa zamanda kışlasına döneceğini söyleyen askerlerin gitgide siyasete 1sındıklarını ve böylece bir baskı rejiminden başkasına geçildiğini düşünmeye başlayan bazı halk kesimleri, Anayasa oylamasına olup bitenlerin sorumlusu gördükleri C.H.P.'ye karşı tavır göstergesi gibi katılmışlardı. Olumsuz propagandaların da etkisiyle verilen "hayır" oylarının bir kısmı C.H.P.'yi cezalandırmak için verilmişti. Aynı duygu birkaç ay sonra yapılan ve C.H.P.'nin düş kırıklığıyla sonuçlanan genel seçimde de yönlendirici oldu. Yassıda kararlarının seçimlerden önce açıklanması, C.H.P.'ye oy kaybettirdi.

15 Ekim 1961 günü yapılan ve dört partinin katıldığ 1 genel seçimlerde, son sayımda nüfusu 28771000 olarak saptanmış Türkiye'de sayısı 12295 395 i bulan seçmenlerden 10522 716'sı oy kullanmıştı. Yani, katılım oranı yüzde 81.4 idi. \% 96.3'ü geçerli olan 10138035 oyun \% 36.7 si 3724 752 ile Cumhuriyet Halk Partisi , \% 34.8'i 3527435 oyla Adalet Partisi; \% 14 ü 1415390 ile Cumhuriyetçi Köylü Millet Partisi; \%13.7'si 1 391 934'ü Yeni Türkiye Partisi için kullanılmıştı. 81732 (\% 0.8) oy da bağımsızlar için

\footnotetext{
${ }^{123}$ Öztürk, Kazım , a.g.e ., Cilt III, s. 3940.
} 
kullanılmıștı. Bu durumda Parlamento'ya C.H.P.'den 173 milletvekili ve 36 senatör, A.P'den 158 milletvekili ve 71 senatör, C.K.M..P. 'den 54 milletvekili ve 16 senatör, Y.T.P.'den de 65 milletvekili ve 13 senatör ${ }^{124}$ girmişt. Seçimden tam on gün sonra yeni meclis, çalışmalarına başladı.

Askeri darbeler tarihinde görülmeyen bir şekilde, karşı ihtilal olmadan askeri yönetimin sivile bırakıldığ 27 Mayıs hareketi, araştırmacıların değerlendirmelerine açık olarak tarih sayfalarında kaldı. Demokrasi ve gönenç söz vererek ezici oy çokluğuyla başa gelen yönetimin baskıcı rejime dönüşmesi, bağımsızlığı zedeleyen dış bağlantılar, üniversite öğrencileriyle halkın elele katıldığı sokak gösterileri, kalabalıkların arasına dalan coplu polisler, sıkı yönetim tutuklamalarından askeri müdahaleye ve devletin en üst makamları dahil, onca siyasinin tutuklanıp yargı önüne çıkarılmasına, idama kadar varan cezalara çarptırılmasına kadar çoğu o zaman ilk kez yaşanan olayların ruhlardaki izlerini bir kenara koyuvermek çok zor. Bunlar, 27 Mayıs'ın anılar daha küllendikçe, daha uzun vadede değerlendirilecek yüzü. Ancak, bir yüzü de, unutturulmaya çalışılsa da getirdiği sosyal haklar ve güvencelerle, başlattığı bilinçlenmeyle Türk toplumunu Atatürk'ün özlediği ve elbette bir gün ulaşacağı çağdaş uygarlığa yöneltmekte önemli bir rol oynayan 1961 Anayasası'dır.

1961 Anayasası, referandumla kabul edilen şekliyle ancak on yıl uygulanabildi. Anayasa'nın getirilerinin önemini o anda sadece halkın bir kesimi algılayabilmişse de yol açtığı aydınlanma, Türk toplumuna insanca yaşamak yönünde geri dönüşü olmayacak ilerleme getirdi. Tutanaklardan da gözlenebildiği gibi, yüksek öğrenim süzgecinden geçmiş Senatörler, yasama, yürütme organlarındaki görüşmelerde kullanılan konuşma dilini bile etkiledi. Anayasa Mahkemesiyle güçlenen yargı bağımsızlığıyla halkın hukuk ve adalete güveni yükseldi. Yeni kurulan partilerle siyaset sahnesinde sağdan sola uzanan bir yelpaze oluştu. Yeni getiriler yayın yaşamına yansıdıkça toplum, tanımadığı, daha doğrusu tanıyamadığ dünyayı tanımaya, öğrenemediği düşünce tarihini yerli ve çeviri yapıtlardan okumaya, bilinçlenmeye, hakkını öğrenip istemeye başladı. İş yaşamına yansıyan getirilerle sağlıktan, çalışma koşullarının iyileştirilmesinden emekliliğe kadar uzanan sosyal güvenlik önlemleri gündeme geldi. Sözleşmeler yapıldı, sendikalar kuruldu, büyük sermaye sahiplerini, patronları rahatsız ve mağdur eden grevlere gidildi. Ekonomide iş hacminin genişlemesi için yatırımcıları yüreklendirmek üzere sunulan olanaklarla birlikte devlet, özel ve kamu sektörü dengesi, planlı kalkınma, kooperatifçilik, adil toprak mülkiyetinin gözetilmesi gibi iktisadi ve sosyal yaşamı düzenleyecek görevler üstlendi. Kamuoyunun yurt ve dünya

${ }^{124}$ Aydemir, Şevket Süreyya, Cllt III., s. 542-43. 
gelişmeleri hakkında bilgi sahibi olması insanlık gereği görülerek basın özgürlüğünün ve o günlerin en yaygın haber alma aracı radyonun özerkliğinin korunması benimsendi. Üniversitelerin özerkliği önemsendi. $\mathrm{Ne}$ var ki sayılanlara halkın ve yürütücülerin tam uyumu, bilgi, bilinç ve zaman gerektiriyordu. Bu zaman içinde yönetim kadrolarında söz sahibi olanlardan kimileri, getirilen hakların topluma bol geldiğini öne sürerek geleneksel şark kurnazlığıyla her birini delme yolları aramaya başlayınca ve küçük çıkar hesaplarıyla onları alkışlayanlar olunca, ülkede yeniden Demokrat Parti döneminde yaşananlara benzer veya depdeğişik sarsıntılar baş gösterdi. Okur yazarlığın eğitim sanıldığı, siyasete alet edilen eğitim sistemiyle bir türlü bilimin ışığına kavuşamayan halkı yönlendiren çıkarcı siyasilerin topluma böylece yaşattığ 1 bunalımların sorumlusu hükümetler değil, Anayasa olarak görüldü. Sosyal haklara verilen önemi ve öncelikleri 12 Mart dönemi Başbakanı Prof. Dr. Nihat Erim tarafından lüks olarak tanımlandıktan sonra, sık sık değişikliklere uğradı. Ve sonunda, 12 Eylül dönemine kadar yürürlükte kaldıktan sonra 27 Mayıs'ı ders kitaplarından çıkartan başka bir askeri hareketle yerine cumhuriyetin temel ilkelerinin yara aldığı yeni bir Anayasa getirilerek yürürlükten kaldırıldı. Bununla birlikte, 12 Eylül Anayasası'nda bile, pek istenmese de çağdaşlık gereği olduğundan 1961'in Anayasal kurumlarına yer verildi.

Bugün geriye bakıldığında görülen bir gerçek, Türkiye'ye çağdaş hukuk devleti olma yolunda pek çok artılar getiren 1961 Anayasası'nın ülkeye aydınlık yollar açan yeni kurumlarla, kamuoyu çıkarını sağlayacak maddelerle donatılmasında, hazırlanırken yapılan incelemeler, araştırmalar, anketlerin rolü kadar Meclis aritmetiğinin kamuoyu aleyhine işleyebileceği kaygısının da bulunmasıdır. Üzücü noktaysa, zamanın bu kaygıyı haklı çıkarmasıdır. Unutmamak gerekir ki Anayasa yürürlükten kaldırıldıktan sonra bile Meclis'te oy çokluğuna sahip iktidarların laik T.C. devletini tehdit eden uygulamalara, bütünlüğünü gölgeleyecek kayıtlara sarılamaması, 1961 Anayasası'nın özüyle değilse de kavramları ve kurumlarıyla hala canlılığını koruyan, demokrasi ve insan haklarına dayalı çağdaş çizgisi sayesindedir. 
Ankara Üniversitesi Türk İnklâp Tarihi Enstitüsü Atatürk Yolu Dergisi S 43, Bahar 2009, s. 455-465

\title{
Cumhuriyet Kültü̈rü
}

\section{Yrd. Doç. Dr. Mithat ATABAY*}

\section{$\ddot{O Z Z E T}$}

Kurtuluş Savaşından sonra, modern Türkiye’nin kurucusu Atatürk ulus devletin kökleşmesi ve Türkiye'nin çağdaşlaşması için siyasal, hukuki, ekonomik ve sosyal alanlarda kapsamll bir reform hareketi başlattl. Atatürk’ün başlıca hedefi Türkiye'nin modern Avrupa Devletleri arasında yerini alması idi. O, Osmanlı Imparatorluğunun küllerinden laik ve dermokratik bir cumhuriyet rejimi kurmayl başardı. Bu Türk halkı açısından gerçek bir kültürel devrimdi. Atatürk döneminde Türkiye sosyal, siyasal, ekonomik, hukuksal ve kültürel alanlarda önemli atılımlar yaptı ve Cumhuriyet kültürünü yerleştirdi.

II. Dünya Savaşı Atatürk tarafindan başlatılan reform hareketlerini yavaşlattı. Savaştan sonra, Yeni Dünya Düzeni Türkiye’yi etkiledi ve Atatürk'ün reformlarından ve amaçlarından bazı noktalarda sapmalara yol açtı. Bu siyasal atmosferde onun ilkeleri ve reformlarından bazıları sorgulanmaya ve eleştirilmeye başlandl. Ancak, Türkiye Atatürk'ün koyduğu modernleşme idealinden vazgeçmedi.

Anahtar Kelimeler: Atatürk reformlarl, cumhuriyet kültürü, Türk devrimi, modernleşme

\section{Republic Culture}

\begin{abstract}
After the War of Independence, Mustafa Kemal Atatürk, the founder of Modern Turkey, inaugurated a series of important political, economic and social reforms in order to consolidate the nascent nation-state and to modernize Turkey. The main goal of Atatürk was to place Turkey among the modern European states. He managed to build-up a secular and democratic republic from the ashes of the Ottoman Empire. What he accomplished, in fact, was a cultural revolution for the Turkish people. During the Atatürk period, Turkey made important development in
\end{abstract}

* Çanakkale Onsekiz Mart Üniversitesi, Fen-Edebiyat Fakültesi, Tarih Bölümü, Rektörlük Atatürk İlkeleri ve İnkılap Tarihi Bölüm Başkanı 
social, political, economic, juristical and cultural aspects and strenghtened the republican culture.

The World War II slowed down the reform movements initiated by Atatürk. After the war, the new world order influenced Turkey and caused some deviations from Ataturk's reforms as well as his goals. In this political atmosphere some of his principles and reforms started to be questioned and critisized. However, Turkey did not gave up his modernization ideal.

Keywords: Atatürk's reforms, republic culture, Turkish revolution, modernization

29 Ekim 1923'te Türkiye'de cumhuriyet ilan edildiği zaman yeni rejimin en önemli sorunlarından birisi Türkiye'de bir cumhuriyet kültürü oluşturabilmekti. Osmanlı Devleti'nin altıyüz yıllık uzun devlet hayatında temel alınan olgu çok uluslu bir yapı ve bu yapının yanında İslam dininin etkisi ile oluşan bir kültürel birikimdi. Şimdi bu birikimin yerine yepyeni bir anlayışın eseri olarak cumhuriyet rejimini kurmak oldukça zordu. Bu zorluk daha "cumhuriyet" sözcüğünün ilk kez açıkça ifade edildiği 1923 yılı Eylül ayının sonlarından itibaren kendini göstermeye başladı.

Toplumda Osmanlı Devleti'nin kalıntısı olarak varlığını devam ettiren dinsel temele dayalı kültürel birikim ile 19.yüzyılın sonlarından itibaren hızlı bir gelişme gösteren siyasal akımların cumhuriyet rejimi ile ne şekilde bağdaştırılabileceği sorunu ortaya çıktı. Eski İmparatorluk kültürünün temsilcileri kendi düşüncelerine ve birikimlerine uygun bir yönetim hayalini sürdürürken konu saltanat ve halifelik noktasında düğümleniyordu. Bu çerçevede daha cumhuriyet kurulmadan önce, cumhuriyet rejimine karşı açıktan açı̆̆a muhalefet kendisini göstermişti. Mustafa Kemal ve yakın çalışma arkadaşları eski kültürün yerine yeni rejim olarak cumhuriyeti oturtabilmek için siyasal kararların yanında bir de cumhuriyet kültürü oluşturmaya dönük planlı bir kültürel politika uygulamak zorunda olduklarını görmüşlerdi.

Türk halkı, yaklaşık son ikiyüz yıldır büyük bir değişim süreci yaşamıştı. Bu değişim toplumda kültürel açıdan da sarsıntılara ve karmaşalara yol açmıştı. Bu karışıklık günümüzde de devam etmektedir. "Tarihin köprüsü" olarak adlandırılan Anadolu üzerinde yaşayan Türkler, tarihin değişik dönemlerinden kalma değişik kültürlerin varlıklarını sürdürdükleri toplumsal yapıyı bugün de yaşatmaktadırlar. Anadolu'nun çeşitli yöreleri birbirlerinden çok farklı kültürleri bünyesinde barındırmaktadır. Trakya'da Avrupa kültürünün, Ege'de Akdeniz kültürünün, güney illerinde Arap kültürünün, doğuda Fars kültürünün kuzeydoğuda ise Kafkas kültürünün etkileri dikkatimizi çeker. Orta 
Anadolu'da ise tarihin değişik dönemlerinden kalma kültürel değerler bugünün kültürel değerlerinin potasında erimeye çalışmaktadır. Görüldüğü üzere Türk toplumunun içinde barınan farklı kültürel değerler değişik grupların ve kültürel anlayışların gündeme gelmesine neden olmuştu. Türkiye bir anlamda farklı kültürlerin birbirleriyle mücadele alanıdır. Atatürk, tüm bu farklı kültürel anlayışları akılcı ve yerinde bir değerlendirmeye tabi tutarak, "ortak ulusal bir cumhuriyet kültürü" oluşturma çabasına yönelmişti.

\section{Peki, Kültür Nedir?}

Kültür; "bir toplumda geçerli olan ve gelenek halinde devam eden her türlü dil, duygu, düşünce, inanç, sanat ve yaşayış öğelerinin tümü” olarak tanımlandığında halkın tüm etkinliklerini içine alır. Dolayısıyla kültürün kaynağı da "halk"tı.

Atatürk'ün, Osmanlı İmparatorluğu'nun yıkılması, parça parça olan Anadolu'daki halkın bir merkezî otorite etrafında toplanarak emperyalist güçlere kafa tutması, onları toprağından atması, uygarlık yarışında çağdaş ülkeler düzeyine ulaşmak ve onu aşmak amacı vardı.

$\mathrm{Bu}$ amacı gerçekleştirmek için en önemli ve ilk adım halkın katılımıyla millet etrafında devletleşmenin gerçekleştirildiği Türkiye Büyük Millet Meclisi'nin 23 Nisan 1920'de açılmasıdır. TBMM'nin açılması Türk tarihinde Türklerin tarih sahnesine çıkışından itibaren var olan milletleşme anlayışında köklü bir değişiklik yapmıştır. Bu tam bir "kültür devrimi”"dir ve bundan sonra yapılan bütün reformlar da "Atatürk Önderliğinde Kültür Devrimi"(1) olarak adlandırılır. Atatürk devrimini niçin bu isimle adlandırmak gerekir? Bunun cevabı Atatürk'ün şu sözlerinde yer alır: “Türkiye Cumhuriyeti'nin temeli kültürdür... Kültür okumak, anlamak, görebilmek, görebildiğinden mana çıkarmak, intibah almak, düşünmek, zekâyı terbiye etmektir. Yine insan, enerjisiyle ve fakat tabiatın ona iltifat edildikçe tükenmez yardımıyla, yükselen, genişleyen insan zekâsı, hudutsuz kavrayıs anlamında "insanım" diyen bir vasf-ı mahsusu olur. Insan, hareket ve faaliyetin, yani dinamizmin ifadesidir. Bu böyle olunca kültür, yukarıda işaret ettiğimiz, insanlık vasfinda insan olabilmek için bir esasî unsurdur. Bunu kısaca izah edelim: Kültür, tabiatın yüksek feyzleriyle mesut olmaktır"(2). Atatürk'ün yaptı̆̆ı tanım, toplumun tüm hayatını içerir. O nedenle de onun sağlığında yapılanlar tüm Türkiye'de "devrimler dönemi" olarak kabul edilir ve bu bir kültür hareketidir. Atatürk Önderliğinde Kültür

(1) Yapılan devrimlerin “Atatürk Önderliğinde Kültür Devrimi” olarak isimlendirilmesi konusunda, bkz., Atatürk Önderliğinde Külttür Devrimi, Kalkınma İçin Bölgesel İşbirliği (RCD) Semineri Tebliğleri (9-11 Kasım 1967), Türk İnkılâp Tarihi Enstitüsü Yayınları, Ankara 1972. s.271-272.

(2) Bkz., Afet İnan, Atatürk Hakkında Hatıralar ve Belgeler,4.Bask1, Ankara 1984, 
Devriminin temelinde kişinin kulluktan çıkarak vatandaş olması, toplumun ise ümmet olmaktan kurtularak ulus bilincine erişmesi yatar. Bu ise insanın aklını kullanması ve bilimi esas almasıyla mümkündür. Kişinin aydınlanması esasına dayanır ${ }^{(3)}$. Türkiye Cumhuriyeti'nde kişinin aydınlanması, aydınlanma felsefesinin temelini oluşturan aklın kullanılması, bireye önem verilmesi ve bilginin yaygınlaştırılması ilkelerinin hayata geçirilmesi ile mümkün olmuştur. Bu anlamda akıl ve bilimin toplumda etkin olabilmesi sadece kişiye has olan bir durum değil, aynı zamanda toplumsal bir bilincin oluşması yani bir dil, tarih ve kültür sorununun giderilmesine bağlıdır ${ }^{(4)}$. Cumhuriyet aydınları, bunun başarılması için dinin etkisinden kurtulmuş bir milliyetçiliği, ulusal kültüre ve evrensel anlayışa götüren yol olarak gördüler ${ }^{(5)}$. Yapılan devrimlerde din vurgusu kaldırılmış milliyetçilik ve lâiklik kavramları ön plana çıkarıldı ${ }^{(6)}$.

Mustafa Kemal'in ölümüyle birlikte Türkiye'de yeni bir dönem başlamıştır. 1939-1945 yıllarını içeren bu dönem kültürel politikalarda "hümanizma" dönemidir ${ }^{(7)}$. Aynı zamanda Atatürk önderliğinde yapılan kültür devriminin de tartışılmaya başlandığı sürecin başlangıcıdır.

Türkiye'de kültür politikalarının uygulanması konusunda isminden en çok söz edilen kişi hiç kuşkusuz Hasan Ali Yücel'dir. Hasan Ali Yücel'in 1939 yılında Milli Eğitim Bakanı olmasıyla yeni bir sentez dönemi olan "hümanist kültür" dönemi başladı. Hasan Ali Yücel'in, Ziya Gökalp'in "Türkleşmek, İslâmlaşmak, Muasırlaşmak" formülüne karşı sentezi şudur: "Bugünkü Türk inkılâbr eklemeci değil, bütüncü ve sistemcidir. Biz Ziya Bey'in dediği gibi üç şey olmak istemiyoruz; dileğimiz bir şey olmaktır. Biz tam Türk olmak istiyoruz. Dikkatinizi çekmek istiyorum ki, Türkleşmek başka şeydir, Türk olmak başka. Meşrutiyetin eklemeci filozofunun zannettiği gibi bizim Türkleşmeye ihtiyacımı yoktur. Bizim için, Türklü̈̆̈̈müzü duymak ve bulmak zaruridir" ${ }^{\prime(8)}$. Bunun için halka inmek, Anadolu'nun kendi kaynaklarına dönmek, dünyada ortaya konulmuş eserleri çevirmek ve en önemlisi de Türk halkını çağdaş kültürle donatmak gerektir. Türkiye'de ulusal bir "kültür bilinci" yaratılmalıdır. Çünkü sağlam bir ulusçu bilince, güçlü bir kişisel din bilincine ve hatta meslek bilincine sahip olan bir toplumun kültür bilincinden yoksun olması aklın alacağı bir şey değildir ${ }^{(9)}$. Kültür bilincinden yoksun bir toplum yüzyılların birikimi olan

(3) Bkz., Macit Gökberk, "Aydınlanma Felsefesi, Devrimler ve Atatürk," Çă̆daş Düşüncenin Ișı̆̆̆ında Atatürk, 2.Baskı, İstanbul 1986, s.281-332.

(4) Bkz., Niyazi Berkes, Türkiye'de Cağdaslasma, 2.Baskı, İstanbul 1978, s.534.

(5) Bkz., Şerafettin Turan, Türk Kültü̈r Tarihi Türk Kültüründen Türkiye Kültürüne ve Evrenselliğe, Ankara 1990.

${ }^{(6)}$ Bkz.,Orhan Koçak, "1920'lerden 1970'lere Kültür Politikaları,” Modern Türkiye'de Siyasi Düşünce Kemalizm, c.II, İstanbul 2001, s.370.

(7) a.g.e., s.393.

(8) a.g.e., s. 394

(9) Bkz., Suat Sinanoğlu, Türk Hümanizmi, 2.Bask1, Ankara 1988, s.55. 
deneyimlerinden ders alamayacağı gibi, bu deneyimleri değerlendirip dile getiren büyük insanların önderliğinden de yararlanamaz. Bu değerleri tüm insanlıkla da paylaşamaz.

Mustafa Kemal'in başlattığı kültür devrimi, 1939'dan itibaren uygulanan kültür politikalarıyla "Türk hümanizması"na dönüştü ${ }^{(10)}$. Millî Eğitim Bakanlığı tarafından, 1939 yılında düzenlenen Türk Neşriyat Kongresi'nde dünya klasiklerinin çevrilmesine karar verildi. Hemen Tercüme Dergisi'nin yayınına başlandı. Dünya klasiklerinin çevrilmesinin Türk hümanizmasının doğmasına katkısı konusunda dönemin Millî Eğitim Bakanı Yücel şöyle demiştir:(11) "Hümanizma ruhunu anlama ve duymada ilk aşama, insan varlı̆̆ının en somut anlatımı olan sanat yapıtlarının benimsenmesidir. Sanat dalları içinde edebiyat, bu anlatımın düşünce öğeleri en zengin olanıdır. Bunun içindir ki, bir ulusun diğer ulusların edebiyatlarını kendi dilinde, daha doğrusu kendi düşüncesinde yinelemesi, zekâ ve anlama gücünü o yapıtlar oranında artırması, canlandırmast ve yeniden yaratması demektir. İşte çeviri etkinliğini, biz bu bakımdan önemli ve uygarlık davamı için etkili saymaktayız." Çevrilen dünya klasikleri 1945 yılı sonuna kadar 467'yi buldu.

Bilginin yaygınlaştırılması için, 1941 yılında "İönü Ansiklopedisi" çıkarılamaya başlandı. Yayınların okuyucuya ulaştırılması için Bakanlığın kitap yerleri, okuma salonları çoğaltıldı ve yaygınlaştırıldı. Güzel sanatların geliştirilmesi çabalarına hız verildi. 31 Ekim 1939 tarihinde Ankara'da ilk Devlet Resim ve Heykel Sergisi açıldı. Ankara Konservatuarı yeniden düzenlenerek 1940 yılında Devlet Konservatuarı haline getirildi. Türk Operası hayata geçirildi. 1940 yılında halk oyunlarının Türkiye'deki sergileniş biçiminde önemli bir değişim yaşandı. 19 Mayıs kutlamalarında Gazi Eğitim Enstitüsü öğrencileri Sivas, Erzurum ve Çorum yörelerine ait halk oyunlarını geniş bir izleyici topluluğuna sundular ${ }^{(12)}$.

Ancak halk ile aydınlar arasındaki kültür farklılığı tüm çabalara rağmen giderilemedi. Cumhuriyetin yaratmak istediği kültürel kimlik içerisinde çağdaş toplumu oluşturmak için yapılan çabalarda halkın katılımı büyük ölçüde mümkün olamadı. Bu da halk kültürü ile aydın kültürü arasında farklılığın devamına neden oldu. Cumhuriyetin ortaya koyduğu "vatandaşlık" kavramı her ne kadar genel kabul görmüş gibi görünse de "ümmet" düşüncesi de varlığını bilinçaltında korudu. Şerif Mardin'e ${ }^{(13)}$ göre; "Kemalizm bu anlamda kültürün kişilik yaratıcı katında yeni bir anlam

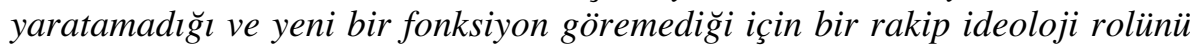
yerine getirememiştir.” Bunun yerine getirilememesinin nedeni II. Dünya

\footnotetext{
(10) Bkz., Şerafettin Turan, İsmet İnönü Yaşamı, Dönemi ve Kişiliği, Ankara 2000, s.217.

(11) a.g.e., s.218.

${ }^{(12)}$ Bkz., Arzu Öztürkmen, Türkiye'de Folklor ve Milliyetçilik, İstanbul 1998, s.243.

(13) Şerif Mardin, Din ve İdeoloji, 3.Bask1, İstanbul 1986, s.111.
} 
Savaşı sırasında cumhuriyetin değerlerine rakip düşüncelerin yeniden ortaya çıkması, bu düşüncelerin, içten ve dıştan da destek bularak yaratılan kültür devrimine karşı eleştirilere başlamasıdır.

II. Dünya Savaşı'na kadar geçen süreçte Ziya Gökalp'in düşüncelerinin yerini akılcı ve lâik bir anlayış aldı. Ancak II. Dünya Savaşı'nın başlaması ile Gökalp'in görüşleri yeniden gündeme geldi ve Türkçülüik Almanya'nın da etkisiyle "tek tarih, tek dil, tek kültür" esasına dayalı düşüncelere yöneldi. $\mathrm{Bu}$ dönemde "dilde, fikirde ve işte birlik" yeniden simgeleşti ${ }^{(14)}$. Dilde olduğu gibi, Ziya Gökalp'in tarihe bakışı da savaş sırasında yeniden canland ${ }^{(15)}$. Türklerin bilimde, sanatta, çiçekçilikte, eğitimde ve müzikte uygarlık yaratıcısı olduğ ${ }^{(16)}$ vurgulanarak, II. Dünya Savaşı'nda Avrupa uygarlığının yıkılmaya başladığı ve Avrupa'nın bundan sonra Türk bilimine, kültürüne ve bilim adamına gereksinim duyacağı ve Avrupalıların Türkleşmek zorunda kalacağı ileri sürüldü.

II. Dünya Savaşı sırasında kültür konusunda ortaya çıkan ikinci eleştiri grubunun temel düşüncesinde ise Anadolu'nun 1071'den itibaren vatan olarak kabul edilmesi kavramı yatar. Bu düşünce Mustafa Kemal'in Anadolu'yu vatan olarak kabul etmesi dışındaki tüm görüşlerine karşıdır. Başlangıçta vatan kavramında Mustafa Kemal'le hem-fikir olan bu grup, daha sonra Mustafa Kemal'in devrimciliği benimsemesi karşısında, kültüre dayalı gelenekçilik ve muhafazakârlı̆̆a yönelmiştir.

II. Dünya Savaşı sırasında kültür konusundaki üçüncü karşıt düşünce, Atatürk'ün devrim, din ve milliyetçilik kavramlarını birleştirmeyi ve orta bir yol bulmayı amaçlayan akımdır. Bu düşüncenin temel sloganı devrimcilik değil, evrimciliktir. Gerek dinin, gerekse geleneklerin "devletin nüfuz sahast dışında kaldı ğı" ve geleneksel yapıda ve kültürde devlet gücüyle yapılmak istenen veya yapılan değişikliklere tepki olarak doğmuştur. Bu çerçevede devrim döneminin sona erdiğini, devrimin gereksinimlere vereceği cevabı verdiğini ve bugün yerini başka bir teze bırakması gerektiği savunulur. Hatta bu tezi savunanlara göre, durum ulusun artık "kendi kendine düşünüş tezidir. Türkiye'de devrimler döneminin sona erdiği ve "millî intibah devri (ulusal uyanma devri)"nin başladığını, bu sayede devrimlerle örf, adet, gelenek ve göreneklerin birleşerek ulusal kültürü yaratma dönemine geçildiği şeklinde algilanmaktadir ${ }^{(17)}$.

\footnotetext{
(15) Bkz., Hasan Ferit Cansever, "Türkçülük Nedir?," Doğu, say1: 9-10-11(TemmuzEylül 1943), s.14-15.

(16) Bkz., Peyami Safa, "Biz Avrupalı Mıyız?," Çınaraltı, sayı:59(İkinciteşrin 1942), s.4.

(17) Bkz., Mithat Atabay, Cok Partili Dönemde Bir Muhalefet Partisi:Millet Partisi $(20$ Temmuz 1948-27 Ocak 1954), (Basılmamış Yüksek Lisans Tezi, A.Ü. Sosyal Bilimler Enstitüsü, T.C. Tarihi Bilim Dalı, 1991), s.96-100.
}

(14) Bkz., Hüseyin Hüsnü Emir Erkilet, "Öz Dilimiz,” Çınaraltı, sayı: 9(Birinciteşrin 1943), s.4 
Atatürk önderliğinde yapılan kültür devrimi ve onu takip eden hümanizma dönemine karşı II. Dünya Savaşı sırasındaki tepkilerin özü üç boyutludur. Birinci boyutu; kültürün menşei, kaynağı ile ilgilidir. İkincisi; yapılan devrimlere yani içeriğe ilişkindir. Üçüncüsü ise; uygulama ile alâkalıdır.

Ziya Gökalp'in kültür çizgisini yeniden canlandırmak isteyenler ile din, milliyetçilik ve Atatürk devrimi arasında orta bir yol bulunmasını savunan geleneksel düşünceler Türk kültürünün Orta Asya, komşu ülke kültürleri (Çin, Hint) ve İslâm (Arap, İran) kültürlerinden oluştuğu temeline dayanır. Anadolu kültürünü savunanlar ise Orta Asya, İslâm kültürü (Arap, İran) ve Anadolu yerli kültürlerinin etkisinin toplumda etkin olduğu düşüncesindedirler. Halbuki Türkiye, son ikiyüz yıldır Batı (Avrupa) kültürü ile iç içedir. Ancak bu unsur da dahil edildiğinde Türkiye kültürünü ulusal ya da evrensel boyuta taşıma olanağı olacaktır.

Mustafa Kemal Atatürk’ün 1925, 1928, 1931, 1932 ve 1934 yıllarındaki devrimleri Atatürk'ün Türk halkını çağdaş uygarlık değişimi alanı içine soktuğu değişimlerdir.

II. Dünya Savaşı sırasında Atatürk devrimlerinin uygulanmasında karşılaşılan ve eleştiriye tutulan ilk kanun "Soyadı Kanunu" olmuş ve özellikle 1942 yılı boyunca bu konuda basında tartışmalar yaşanmıştır.

II. Dünya Savaşı'nın son yılında 20 Nisan 1924 tarihli Teşkilât-ı Esasiye Kanunu metni öz Türkçe sözcüklerle yazılmış ve düzenlenen ve ismine "Anayasa" denilen metin 10 Ocak 1945 tarihinde Türkiye Büyük Millet Meclisi'nde kabul edilmiştir.

Türkiye II. Dünya Savaşı'na fiilen girmemesine karşın, savaşın etkilerinden kurtulamadi. Avrupa'da savaş, 7 Mayıs 1945 'te sona erdi. 1945 başlarında savaşın müttefiklerin başarısıyla biteceğini gören Türkiye, Birleşmiş Milletlerin kurucu üyesi olabilmek için 23 Şubat'ta Japonya ve Almanya'ya savaş ilân etti ${ }^{(18)}$. Bundan sonra Türkiye, 5 Mart'ta San Francisco Konferansı'na resmen davet edildi ve Birleşmiş Milletlerin kurucu üyeleri arasında yerini ald $^{(19)}$. Böylece savaş sonunda yeniden şekillenecek olan dünyada yerini belirlemiş oldu. Bu yer demokrasi ile idare edilen ülkelerin yanıdır.

Savaş sonrasında toplumda genel olarak iki grup belirdi. Devrimciler ve muhafazakârlar. Devrimciler, durumdan pek memnun değillerdi ve daha köklü reformlar istiyorlardı. Muhafazakârlar ise, teknolojik yenilikleri kabul

(18) Bkz., Feroz Ahmad ve Bedia Turgay Ahmad, Türkiye'de Çok Partili Politikanın Açıklamalı Kronolojisi 1945-1971, Ankara 1976, s.12.

(19) Bkz., Ahmet Şükrü Esmer ve Oral Sander, “II. Dünya Savaşı'nda Türk Dış Politikası," Olaylarla Türk Dış Politikası, c.I, 6.Baskı, Ankara 1987, s.184. 
etmekle birlikte devrimlere kesinlikle karşı çıkmakta, kültürün yeni bir değerlendirilmesinin yapılması gerektiğini savunuyorlardı. Bu iki grubun zıtlaşmasına karşılık zaman içinde üçüncü bir grup daha kendini gösterdi. Mutediller diyebileceğimiz bu grup, Türkiye'deki devrimi çağdaş toplum yaratmak için yeterli sayıyorlar ancak bazı devrimlerin aşırı olduğunu vurgulayarak bunların yeniden gözden geçirilmesini istiyorlardı ${ }^{(20)}$.

Savaşın sona ermesiyle başlayan liberalizm akımı Türkiye'de de etkisini gösterdi. Tek parti döneminin uygulamaları tartışılmaya başlandı. $\mathrm{Bu}$ durum, uygulanan kültür politikalarına da yansıdı ve hümanist kültür dönemi de fiilen sona erdi. Bu döneme damgasını vuran "Öner-Yücel Davası" yoluyla Hasan Ali'nin kişiliğinde cumhuriyet rejiminin getirdiği bütün kültürel değişiklikler ve devrimler sınand ${ }^{(21)}$.

Hasan Ali Yücel'in bakanlıktan ayrıldığı 1946 yılına kadar 467'yi bulan klasikler 1950'ye kadar 676'ya ulaştı. 1966 yılına kadar devam ettirilen klasik çevirilerinin sayısı 973'tür.

Halkevleri 1932 yılından itibaren açılmaya başladı ve 1946 yılında sayıları 455'ti. 1950 yılında ise 478 'di. Halkodaları 1940 yılından itibaren faaliyet göstermeye başladı, 1946'da sayıları 4066, 1950'de ise 4332 idi.

1940 yılında açılan Köy Enstitüleri, kısa sürede gelişti ve 1944'te enstitü sayısı 20'ye ulaştı. 1948'de Van Erciş'te yeni bir enstitü açılınca sayı 21 oldu. 1945-1946 öğretim yılı başında 1609 köye, Köy Enstitüsü mezunu 1853 öğretmen ve 665 köy sağlık memuru atandı. Köylerde yapılan okul, işlik ve öğretmen evlerinin sayısı da 3490'a ulaştı. Enstitülerin açıldığı 1940'dan itibaren de ilkokul mezunu olanların sayısında önemli artış oldu. 1927 'de okuma yazma bilenlerin sayısı \%8.2 idi. Yeni Türk Alfabesinin kabulünden 1938 yılına kadar geçen sürede ilkokul diploması alanların sayısı 262000 'dir. Son beş yılda ise bu sayı 478000'e yükseldi ${ }^{(22)}$. 1947'de Köy Enstitülerinden mezunların sayısı 5447'ye ulaştı. 1950'de okuma-yazma bilenlerin sayısı \%34'tü.

Devletin kültür politikası konusunda izlediği siyasette, iktidar partisinin 1947 yılında yapılan kurultayı bir dönüm noktasını teşkil etti. Bu kurultayda

${ }^{(20)}$ Kemal Karpat, Türk Demokrasi Tarihi, İstanbul 1967, s.268.

(21) Öner-Yücel davası için bkz., Kenan Öner, Öner-Yücel Davası, 3 Kitap, İstanbul 1947-1948; Hasan Ali Yücel, Davam, Ankara 1950; Hasan Ali Yücel, Hasan Ali Yücel'in Açtı̆̆ Davalar ve Neticeleri, Ankara 1950; ayrıca Kenan Öner ve Hasan Ali Yücel arasındaki davanın yorum için bknz., Mithat Atabay, II.Dünya Savaşı Sırasında Türkiye'de Milliyetçilik Akımları, İstanbul 2005, s.331-334.

${ }^{(22)}$ Hasan Ali Yücel, Millî Ĕ̈itimle İlgili Söylev ve Demeçler, Ankara 1993, s.299. 
halkevlerinin çalışmaları, din dersleri, türbelerin açılması, ilahiyat fakültesi ile imam hatip okullarının faaliyete başlamaları konuları tartışı1dı ${ }^{(23)}$.

Kurultayda öne sürülen devrimlerden ödünleri içeren görüşler CHP hükümetleri tarafından uygulamaya konuldu. 1947 yılında Köy Enstitüleri Kanunu'nda önemli değişiklikler yapılarak sistemin işleyişi zaafa uğratıldı. Halkevlerinin iktidar partisinin bir yan kuruluşu olmaktan çıkarılarak özerk bir kurum haline getirilmesi çalışmaları yürütülemedi. 15 Ocak 1949'da biri Ankara'da diğeri İstanbul'da olmak üzere iki İmam Hatip Kursu açıldı. 1 Şubat 1949 tarihinden itibaren ilkokullarda isteğe bağlı din dersleri başladı. 4 Haziran 1949 tarihinde kabul edilen bir kanun ile Ankara İlahiyat Fakültesi kuruldu. "Türk büyüklerine ait olma ve yüksek bir sanat de ğeri taşıma" koşuluyla 1 Mart 1950 tarihli 5666 sayılı kanunla yirmi türbe halkın ziyaretine açıldd ${ }^{(24)}$.

14 Mayıs 1950 'de yapılan seçimlerle Demokrat Parti iktidara geldi. Yeni iktidarın, hükümet programında devrimleri, "tutan" ve "tutmayan" devrimler diye ayırma ve ilk iş olarak "Arapça ezan yasağı"nı kaldırması kültürel politikalarda önemli değişimlerin yaşanacağının ilk işaretleri oldu. Ezan konusunun demagojiye açık olması nedeniyle muhalefet de iktidarla birlikte kabul oyu verdi ${ }^{(25)}$. 8 Ağustos 1951 tarihinde kabul edilen 5830 say1l kanunla halkevlerinin mallarına el konuldu. 27 Ocak 1954 tarih ve 6234 sayılı kanunla Köy Enstitüleri tümüyle öğretmen okullarına dönüştürüldü.

Sonuç olarak; 1920'den 1960'lara uzanan zaman dilimi içerisinde, Türkiye'de izlenen kültür politikaları dört süreçten geçti. Bu sürecin ilk halkasi; Atatürk önderliğinde gerçekleştirilen kültür devrimi dönemi (19201938), ikinci evresi; hümanizma ve aynı zamanda kültür devrime karşı tartışma dönemi (1939-1945), üçüncüsü; evrimcilik dönemi (1946-1950) ve son olarak "tutan" ve "tutmayan" devrimler diye açıkça devrimlerden ödünleri içeren tavizler dönemi (1950-1960)’dir.

Atatürk; halkçılığa, milliyetçiliğe ve lâikliğe önem vererek tarih ve dil tezleri ile yeni bir anlayış yaratmayı hedefledi. Çağdaş bir toplum oluşturmayı amaçladı. Onun döneminde Türk kültürünün ulusal temelleri atıldı. O dönemdeki kültür politikası Atatürk devriminin bir sentezi ve aynı zamanda azgelişmişlik koşullarını kendi çıkarlarının ön koşulu sayanlara karşı da bir hareketti. Bu anlamda olaya bakıldığında bugün her platformda söylenen "sosyal değişim politikası"nın anlamı kültür değişmesidir. Türk toplumunun her alanda çağdaş bir toplum haline gelebilmesi için yapılması

(23) CHP'nin 7.Büyük Kurultayındaki tartışmalar için bkz., CHP Yedinci Büyük Kurultayı, Ankara 1948; ayr. bkz., Çetin Yetkin, Karşı Devrim 1945-1950, İstanbul 2002, s.393-422.

(24) Ziyarete açılan türbeler için bkz., Gotthard Jaschke, Yeni Türkiye'de İslâmlık, Çev. Hayrullah Ors, Ankara 1972, s.104-105.

${ }^{(25)}$ Cem Eroğul, Demokrat Parti Tarihi ve Ídeolojisi, 2.Bask1, Ankara 1990, s.58. 
gereken yeni bir kültür yaratmaktı. Bu da kültürel değişimle, yani anlayıştaki değişimle olabilirdi. Atatürk bunu gerçekleştirdi. Ancak Atatürk dönemindeki bu değişim, kendisinden sonra gelenler tarafından yeni bilgilerle, yöntemlerle geliştirilip, kökleştirilmedi ve yeni bir ekol yaratılamadı. 1940'lardan itibaren önce yavaş, sonra hızlı bir şekilde değişimin hızı kesildi ve hatta bazı alanlarda tamamen durduruldu. Bunun sonucu olarak köklü değişimi kalıcı kılacak ve bir sisteme dönüştürecek unsurlar geliştirilemediği gibi zaman içinde yapılanlar dahi korunamadı. O nedenle de kültür devrimi, çağdaş dünyaya damgasını vuracak bir "Türk rönesansl" haline gelemedi.

Bugün ise; Ulusal ya da evrensel kültürümüz Türk-İslam sentezi olarak nitelenmeye veya ona indirgemeye çalışılmaktadır. Bu çabaları ve anlayışı bilimsel bir yaklaşım olarak görmek doğru değildir. Bu aynı zamanda Türk kültürüne belirli oranda renk ve zenginlik kazandıran kökleri de yadsımak olur. Böyle bir davranış çağdaşlaşma çabalarına ters düşer ve ulusal kültürü çağdaş uygarlık düzeyinin üstüne çıkarma amacıyla da bağdaşmaz.

Atatürk kültürün devlet hayatındaki önemini belirtirken;

"Bir ulus, varlı̆̆ ve hukuku için bütün kuvvetiyle, bütün fikri ve maddi kuvvetleriyle ilgilenmezse, bir ulus, kendi kuvvetine dayanarak varlığını ve

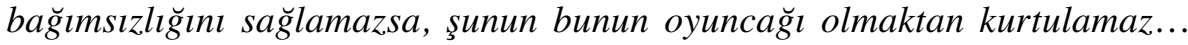
Bireyler düşünür olmadıkça, topluluklar istenilen yöne, herkes tarafindan iyi veya fena yönlere sürüklenebilir. Kendini kurtarabilmek için her kişinin geleceğiyle doğrudan doğruya ilgili olması gerekir."

"Milli kültürün her alanda açılarak yükselmesini Türkiye Cumhuriyeti'nin temel direği olarak sağlayacağız." demiştir.

Kökeni, ortak yaşanmış tarihe dayanan ulusal kültür sayesinde Türkiye Cumhuriyeti'nin sonsuza kadar yaşayacağına inanmış ve bu konuda ana kaynağın da kültür olduğunu vurgulamıştır.

\section{KAYNAKÇA}

Ahmad, Feroz ve Bedia Turgay Ahmad, Türkiye'de Çok Partili Politikanın Açıklamalı Kronolojisi 1945-1971, Ankara 1976.

Atabay, Mithat, Çok Partili Dönemde Bir Muhalefet Partisi: Millet Partisi (20 Temmuz 1948-27 Ocak 1954), (Basılmamış Yüksek Lisans Tezi, A.Ü. Sosyal Bilimler Enstitüsü T.C. Bilim Dalı), Ankara 1991.

Atabay, Mithat, II.Dünya Savaşı Sırasında Türkiye'de Milliyetçilik Akımları, İstanbul 2005.

Berkes, Niyazi, Türkiye'de Çağdaşlaşma, 2.Baskı, İstanbul 1978. 
Cansever, Hasan Ferit, “Türkçülük Nedir?,” Doğu, sayı: 9-10-11 (TemmuzEylül 1943), s.14-15.

CHP, CHP Yedinci Kurultayl, Ankara 1948.

Erkilet, Hüseyin Hüsnü Emir, “Öz Dilimiz,” Çınaraltı, sayı:9 (Birinciteşrin 1943), s. 4.

Eroğul, Cem, Demokrat Parti Tarihi ve İdeolojisi, 2.Baskı Ankara 1990.

Esmer Ahmet Şükrü ve Oral Sander, “II.Dünya Savaşı'nda Türk D1ş Politikası,” Olaylarla Türk Dış Politikası, c.I, 6.Baskı, Ankara 1987.

Gökberk, Macit, “Aydınlanma Felsefesi Devrimler ve Atatürk,” Çăgdaş Düşüncenin Işı̆̆ında Atatürk, 2.Baskı, İstanbul 1986.

İnan, Afet, Atatürk Hakkında Hatıralar ve Belgeler, 4.Bask1, Ankara 1984.

Jaschke, Gotthard, Yeni Türkiye’de İslamlık, çev. Hayrullah Örs, Ankara 1972.

Karpat, Kemal, Türk Demokrasi Tarihi, İstanbul 1967.

Koçak, Orhan, “1920’lerden 1970’lere Kültür Politikaları,” Modern Türkiye’de Siyasi Düşünce Kemalizm, c.II, İstanbul 2001.

Mardin, Şerif, Din ve İdeoloji, 3.Baskı İstanbul 1986.

Öner, Kenan, Öner- Yücel Davası, 3.Kitap, İstanbul 1947-1948.

Öztürkmen, Arzu, Türkiye’de Folklor ve Milliyetçilik, İstanbul 1998.

Safa, Peyami, “Biz Avrupalı Mıyız?,” Çınaraltı,sayı:59 (İkinciteşrin 1942), s.4.

Sinanoğlu, Suat, Türk Hümanizmi, 2.Baskı Ankara 1988.

Turan, Şerafettin, İsmet İnönü Yaşamı, Dönemi ve Kişiliği , Ankara 2000.

Turan, Şerafettin, Türk Kültür Tarihi Türk Kültüründen Türkiye Kültürüne ve Evrenselliğe, Ankara 1990.

Türk İnkılap Tarihi Enstitüsü, Atatürk Önderliğinde Kültür Devrimi, Kalkınma için Bölgesel İşbirliği (RCD) Semineri Tebliğleri (9-11 Kasım 1967), Türk İnkılap Tarihi Enstitüsü Yayınları, Ankara 1972.

Yetkin, Çetin, Karşı Devrim 1945-1950, İstanbul 2002.

Yücel, Hasan Ali, Davam, Ankara 1950.

Yücel, Hasan Ali, Hasan Ali Yücel’in Açtı̆̆ Davalar ve Neticeleri, Ankara 1950.

Yücel, Hasan Ali, Milli Ĕ̆itimle İlgili Söylev ve Demeçler, Ankara 1993. 
